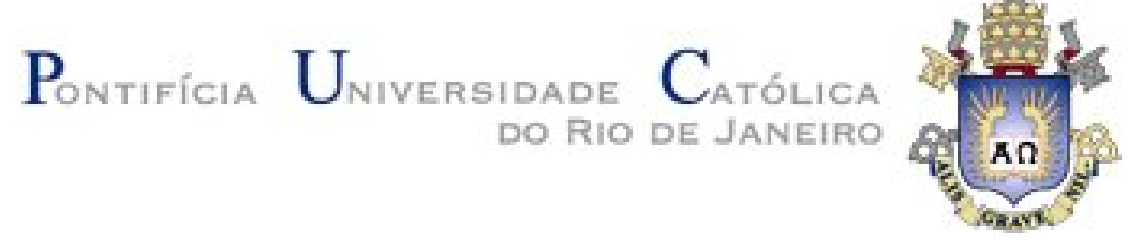

Karla Galal Schwartz

O lugar do Design nas exposições de arte: algumas contribuições para a definição de suas funções.

Dissertação de Mestrado

Dissertação apresentada ao Programa de Pósgraduação em Design da PUC-Rio como requisito parcial para obtenção do grau de Mestre em Design.

Orientador: Prof. Alberto Cipiniuk 
Karla Galal Schwartz

\title{
O lugar do Design nas exposições de arte: algumas contribuições para a definição de suas funções.
}

Dissertação apresentada como requisito parcial para obtenção do grau de Mestre pelo Programa de Pósgraduação da PUC-Rio. Aprovada pela Comissão Examinadora abaixo assinada.

\author{
Prof. Alberto Cipiniuk \\ Orientador \\ Departamento de Artes \& Design - PUC-Rio
}

Profa. Claudia Renata Mont'Alvão Departamento de Artes \&Design - PUC-Rio

Profa. Irina Aragão dos Santos Departamento de Artes \& Design- PUC-Rio

Profa. Monah Winograd Coordenadora Setorial do Centro de Teologia e Ciências Humanas - PUC-Rio 
Todos os direitos reservados. É proibida a reprodução total ou parcial do trabalho sem autorização da universidade, da autora e do orientador.

\section{Karla Galal Schwartz}

Graduou-se em Direito pela Universidade Estadual do Rio de Janeiro (UERJ) em 1998. Graduou-se em História da Arte e Arqueologia pela Université Paris-Sorbonne (Paris IV) em 2009. De 2010 a 2014 ministrou palestras sobre História da Arte no Centro de Atualização da Mulher (CAM). Pósgraduanda do programa de mestrado da PUC/Rio nos anos de 2015-2016, tendo publicado dois artigos nesse período na Revista Tamanduá.

Ficha Catalográfica

Schwartz, Karla Galal

O lugar do Design nas exposições de arte : algumas contribuições para a definição de suas funções / Karla Schwartz ; orientador: Alberto Cipiniuk. - 2017.

152 f. : il. color. ; $30 \mathrm{~cm}$

Dissertação (mestrado)-Pontifícia Universidade Católica do Rio de Janeiro, Departamento de Artes e Design, 2017.

Inclui bibliografia

1. Artes e Design - Teses. 2. Design de exibições. 3. Exposições de arte. 4. Museus. 5. Expografia. 6. Ensino. I. Cipiniuk, Alberto. II. Pontifícia Universidade Católica do Rio de Janeiro. Departamento de Artes e Design. III. Título. 


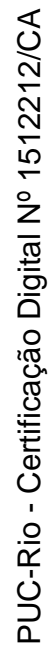

Ao meu saudoso pai e a minha querida mãe. 


\section{Agradecimentos}

A D' que me guia por caminhos de paz e de aprendizado.

Aos meus pais pelo amor incondicional com o qual sempre fui presenteada. Agradeço-lhes por tudo.

Ao meu marido pelo amor e amizade há tantos anos. Ao meu lindo filho, alegria da minha vida.

Ao meu querido irmão, grande amigo e companheiro de vida, à minha cunhada $\mathrm{e}$ sobrinha pelo constante apoio.

Ao professor e orientador Alberto Cipiniuk por me direcionar para a pesquisa e pela sempre atenta e inteligente orientação. Finalmente, pela amizade oferecida desde o primeiro dia em que fui recebida em sua sala.

À CAPES (Coordenação de Aperfeiçoamento de Pessoal de Nível Superior) pela bolsa de estudos concedida.

À PUC-Rio por proporcionar por meio de sua estrutura e biblioteca as condições necessárias para a produção da presente dissertação.

Aos professores Claudia Renata Mont'Alvão, Denise Berruezo Portinari, Irina Aragão dos Santos, José Ribas, Luis Antonio Coelho, Maria Manuela Rupp Quaresma pelas aulas que contribuíram para o desenvolvimento dessa pesquisa.

Aos membros da Comissão examinadora por se disponibilizarem a ler e avaliar a presente pesquisa.

A todos os entrevistados pela gentileza de me receberem e pela sinceridade e generosidade de seus relatos. Aos que responderam ao questionário pelas importantes informações concedidas.

Ao grupo de estudos GRUDAR pelo espaço aberto ao debate e à reflexão.

Finalmente, aos amigos Edite e Carlinhos pela ajuda e lealdade de sempre. 


\section{Resumo}

Schwartz, Galal Karla; Cipiniuk, Alberto. O lugar do Design nas exposições de arte: algumas contribuições para a definição de suas funções. Rio de Janeiro, 2017. 152p. Dissertação de Mestrado Departamento de Artes \& Design, Pontifícia Universidade Católica do Rio de Janeiro.

O Design de Exibições já é bem conhecido e aplicado em museus de arte de diversos países. No Brasil, sua prática em museus de arte se afirmou progressivamente nas últimas décadas. Sua classificação duvidosa como disciplina no Campo do Design e sua complexidade por envolver conhecimentos multidisciplinares faz com que seu ensino em universidades e em cursos de Design ainda não seja uma realidade comum no Rio de Janeiro, talvez no Brasil. Profissionais brasileiros que atuam na área aprendem com o exercício da prática e não com auxílio de uma teoria de base. A concepção e a montagem de exibições de arte exigem trabalho em equipes multidisciplinares. Enquanto esse fato possa trazer uma confluência positiva de conhecimentos variados, também pode gerar dúvidas quanto ao papel de cada categoria profissional envolvida, fazendo surgir possíveis conflitos dentro das equipes. Portanto, julga-se relevante descobrir qual o papel do designer nessa prática e o momento de sua participação. Finalmente, o Design de Exibições pode evidenciar objetos expostos em museus de arte por meio do emprego de narrativa e pelo recurso a cores, luzes, tecnologia, entre outros elementos. Também o Design de Exibições tem a possibilidade de tornar exibições de arte mais amigáveis aos visitantes, porém não se confirmou a hipótese de ser ele um facilitador para uma melhor compreensão do que venha a ser arte e seus conceitos por parte do público.

\section{Palavras-chave}

Design de Exibições; exposições de arte; museus; expografia; ensino; designers. 


\section{Abstract}

Schwartz, Galal Karla; Cipiniuk, Alberto (Advisor). Design's role in art exhibitions: contributions to define its functions. Rio de Janeiro, 2017. 152p. Dissertação de Mestrado - Departamento de Artes \& Design, Pontifícia Universidade Católica do Rio de Janeiro.

Exhibition Design is already well established and applied in art museums in numerous countries. In Brazil, it was progressively practiced in art museums during the past decades. However, its teaching in universities and in design courses is still not a reality in Rio de Janeiro, and maybe in Brazil, due to its doubtful classification as a discipline within the Design Field and due to its complexity, involving multidisciplinary knowledge. Brazilian professionals working in the field learn through practice and are not supported by a theoretical base. The intricate process of elaborating an art exhibition requires multidisciplinary teams. While this fact can bring a positive confluence of varied knowledge, it can also create uncertainty regarding the role of each professional category involved, creating possible team conflicts. Therefore, it is deemed necessary to define the designer's role and the timing of his/ her participation. Finally, Exhibition Design can highlight objects exposed in art museums through narrative and the use of colour, light, technology, among other elements. Exhibition Design can also make art exhibitions more visitor friendly, but the hypothesis that it facilitates the public's better understanding of art and its concepts was not confirmed.

\section{Keywords}

Exhibition Design; Art exhibitions; museums; expography; teaching; designers. 


\section{Sumário}

1. Introdução

2. O termo Design de Exibições e suas competências.

3. Origens do Design de Exibições.

4. Comentários sobre as exibições de arte a partir do século XVII na Europa Ocidental.

5. Aplicação do Design de Exibições em exposições de arte, participação do público, desencriptação.

6. Design de Exibições e sua importância no cenário internacional.

7. O Design de Exibições, sua prática no Brasil e o seu ensino no Rio de Janeiro.

8. O Design de Exibição no Rio de Janeiro. O exemplo do Museu da República.

8.1 O Design de Exibição no Rio de Janeiro. O exemplo do Museu de Arte Moderna do Rio de Janeiro.

8.2 O exemplo do Museu de Arte Moderna do Rio de Janeiro nos dias atuais.

8.3 O sistema de exibição de Karl Heinz Bergmiller.

9. O designer de exibições: momento de atuação e suas funções.

10. Conclusão. 


\section{Lista de Figuras}

Figura 1- Prédio do Bloco Escola do MAM-Rio em 1958

Figura 2- Reidy em frente ao MAM-Rio

89

Figura 3- Exposição lole de Freitas

99

Figura 4- Exposição Ivens Machado

99

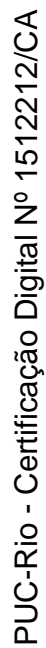

Figura 5- Corredor da exposição Temporama

106

Figura 5.1 - Entrada da exposição Temporama

Figura 5.2- "Piscina" da exposição Temporama

Figura 5.3- Equidistancia do salão 2.4

108

Figura 6- Exposição América do Sul

Figura 7- Still Life de Ron Mueck no MAM 
Figura 9- "Aquário" embaixo da escada

Figura 10- Convite para exposição Marginália 1

Figura 10.1- Homenagem a Rogério Duarte

122

Figura 11. Convite para exposição Temporama

123

Figura 11.1- Bedtime Stories

123

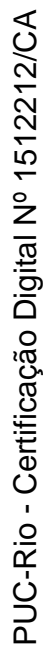

Figura 12- Convite para exposição O Fim da Matéria

124 


\section{Introdução}

Há alguns anos pode-se observar um grande número de exposições de arte apresentadas no Brasil e a proliferação de museus e centros culturais inaugurados em diversas cidades brasileiras nos últimos tempos. Pode-se tentar explicar o motivo em razão da primazia que o ser humano confere à visualidade desde os séculos XIX e XX (ABREU, 2012: 62). Pode-se também, como no caso do Rio de Janeiro, atribuir-se uma possível explicação para o fenômeno em razão de eventos internacionais aqui sediados como à Copa do Mundo e às Olimpíadas.

Entretanto, verifica-se que nem sempre as exposições de arte montadas em museus e centros culturais atraem um público considerável no Brasil, ou pelo menos no Rio de Janeiro. Não sendo esse um fato recente, acredita-se que a partir da década de 1980 o museu brasileiro precisou se reavaliar para caminhar junto com a nova museologia internacional que passava a preconizar a importância do público como alvo predominante das exibições em museus. Sonia Salcedo Del Castillo ensina que a partir da década de 1980, os museus nacionais foram ampliados e o papel do museu conservador e propagador de uma narrativa histórica deu lugar ao de museus hospedeiros e propagadores de pacotes expositivos (CASTILLO, 2008: 230). A autora correlaciona essa mudança do perfil do museu nacional à parceria com novos tipos de ações institucionais promovidos pela máquina da indústria cultura (CASTILLO, 2008: 230) da época citada.

Nesse trabalho tem-se por objeto de pesquisa a verificação da relevância da aplicação do Design de Exibições em exposições de arte no cenário internacional e no Rio de Janeiro, de seu potencial para tornar tais exibições mais atrativas, amigáveis e compreensíveis aos seus visitantes. Avalia-se, ainda, qual a situação atual de seu estudo e ensino em universidades e cursos de Design no acima mencionado estado da federação.

Busca-se finalmente uma definição do momento e do escopo de atuação do designer de exibições de arte brasileiro, a fim de se distinguir quais funções 
deveriam ser preferencialmente exercidas por ele, maximizando-se, portanto, suas habilidades específicas e sua atuação no mencionado processo de construção de exposições.

Nessa pesquisa acredita-se que os museus de arte no Brasil tenham por meta conseguir atrair um bom número de visitantes para suas exposições tal como se verifica em alguns países estrangeiros. Sarah Thornton, em seu livro Sete dias no mundo da arte (THORNTON, 2010), explora detalhadamente o mundo da arte e, já na introdução, referindo-se à visitação a obras de arte contemporâneas na última década, afirma que a visita a museus disparou [...]. Harold K. Skramstad escreve que exposições de arte do tipo blockbuster ${ }^{l}$ são capazes de transformar a percepção do público quanto a museus (SKRAMSTAD, Introduction. In.: KLEIN: 1986:10).

Além de conseguir atrair visitantes para suas exibições, acredita-se que também deva ser uma meta das instituições culturais e museais que exibem arte possibilitarem ao público não iniciado apreciar, entender, mesmo participar do que viu, algo que nem sempre se verifica como constatado em pesquisa realizada na França na década de 1960 (BOURDIEU \& DARBEL, 1969: passim). Ainda nos dias de hoje (2016), talvez por desconhecimento das múltiplas referências visuais e conceituais utilizadas pelas artes plásticas, o público tantas vezes sai das exposições de arte contemporânea que visitou sem necessariamente compreender ou fruir do que era mostrado. Por esse motivo, defende-se ser de grande importância o uso de abordagens expositivas que poderíamos chamar de "educativas", isto é, que visem facilitar a compreensão das artes plásticas pelo público visitante, estimulando-o também no tocante à sua capacidade de apreciação estética das obras de arte. Percebe-se, porém, que nem sempre essa questão tem recebido a atenção devida no Brasil. Na presente pesquisa questionase se o Design de Exibições consegue suprir essa necessidade.

No âmbito acadêmico, segundo Maria Violeta Polo, a produção de teses e de dissertações sobre expografia, termo cujo significado guarda similitudes com o termo Design de Exibições e que é mais comumente empregado em nosso país,

1 Exposições chamadas blockbuster são aquelas cujo tema escolhido e as técnicas expositivas e de marketing utilizadas atraem o interesse de largo público e, consequentemente, arrecadam vultosas receitas para a instituição expositora. 
tomou impulso apenas a partir do ano 2000 (POLO, 2006: 11). Ela prossegue alertando tratar-se de assunto ainda não esgotado apesar do crescente número de pesquisas sobre o tema (POLO, 2006: 13). A autora escreve:

Antes dessa data o material bibliográfico brasileiro direcionado ao estudo da expografia resumia-se basicamente a livros de museologia, que abordam o assunto sob aspectos gerais, além de manuais de museografia, que, como tais, limitam-se a enumerar regras e dados técnicos (POLO, 2006: 11).

O termo expografia, tradução para o português do termo francês expographie, foi um neologismo criado em 1993 por André Desvallées e que consta da sua obra Dictionnaire encyclopédique de muséologie (Dicionário enciclopédico de museologia) escrita em conjunto com François Mairesse em 2011, que serve para

desenhar a criação da exibição e aquilo que concerne à construção do espaço e ao que gira em torno nas exposições (excluindose as outras atividades museográficas como a conservação, a segurança, etc.). ${ }^{2}$

Em outras palavras, como bem sintetiza Dominique Gélinas no artigo Le sensorium synthétique: réflexion sur l'utilisation de l'expographie immersive numérique et muséale $(\mathrm{O}$ sensório sintético: reflexão sobre a utilização da expografia imersiva numérica e museal)

A expografia é o conjunto de técnicas desenvolvidas para garantir a criação da exposição. O expógrafo é aquele que assegura a construção da exibição, mas ele se distingue do cenógrafo e do designer de exibições por seus conhecimentos particulares em museografia, em pedagogia museal e em estratégias de comunicação pela intervenção de diferentes dispositivos. Ele considera igualmente as exigências da instituição museal. ${ }^{3}$

${ }^{2}$ désigner la mise en exposition et ce qui ne concerne que la mise en espace et ce qui tourne autour dans les expositions (à l'exclusion des autres activités muséographiques comme la conservation, la sécurité, etc). DesvalleEs e MAIRESSE, Dictionnaire encyclopédique de muséologie, 2011, p. 599 apud GELINAS, 2000. Disponível em https://cm.revues.org/2000, acesso em 25/12/2016.

${ }^{3} E n$ d'autres mots, l'expographie est l'ensemble des techniques développées pour assurer la mise en exposition. L'expographe est celui qui assure la mise en exposition, mais il se distingue du scénographe ou du designer d'exposition, par ses connaissances particulières en muséographie, en pédagogie muséale et en stratégies de communication parl'intervention de différents dispositifs. II tient compte également des exigences de l'institution muséale. GELINAS, 2000. Disponível em https://cm.revues.org/2000, acesso em 25/12/2016. 
François Mairesse, em artigo publicado em 2010, esclareceu que o termo expografia permanecia até então pouco conhecido. Justificou ser, entretanto, o termo que melhor dá conta da questão dos aparatos de exposição postos em prática tanto pelo museógrafo quanto pelo conservador, por vezes pelo próprio arquiteto, pelo cientista ou pelo amador (MAIRESSE, 2010: 219). ${ }^{4}$

Partimos do pressuposto de que um país até recentemente subdesenvolvido e considerado atualmente a nona potência mundial, deveria possuir além de grandes barragens, estradas e cidades, uma sociedade bem informada sobre artes plásticas que se beneficia por compreender melhor críticas porventura existentes nas obras expostas, podendo participar ativamente de debates sobre a realidade em que está inserida.

Ao longo dos séculos, as artes plásticas têm afirmado diversas funções sociais. Enumeram-se algumas: a função estética, a função educadora, a função de difusora de religião, a função política, a função de suporte do poder institucional e também a função questionadora da realidade em dado tempo e espaço. Pela importância das diversas funções das artes plásticas, acredita-se que o Design de Exibições tem a contribuir enormemente com o desenvolvimento das exposições de arte realizadas em nosso território, e procura-se descobrir na presente pesquisa se sua aplicação auxilia o público a compreender mais facilmente as múltiplas referências que são comunicadas pelas obras de artes quando expostas.

Concordamos com a visão expressa por Maria Polo em sua dissertação de mestrado que, ao buscar entender o papel da expografia nas exposições de arte, afirma que a maneira com que a obra é apresentada influi na recepção $e$ consequentemente nas possibilidades de fruição, compreensão e interpretações do observador, sobre a obra em questão, concluindo ainda que a expografia é conceituada a partir do projeto da concepção curatorial (POLO, 2006: 07).

O designer de exibições, intimamente alinhado à concepção curatorial, planifica o projeto expográfico, isto é, o desenho do espaço ocupado pela mostra, a estipulação ou a liberdade do percurso de visitação, seus painéis, vitrines, bases, suportes em geral, textos e tipografia, cores, iluminação a fim de evidenciar aquilo

${ }^{4}$ S'il convient d'admettre que le terme d'expographie reste bien peu répandu, c'est celui-là que j'utiliserai ici le plus souvent, puisqu'il rend particulièrement bien compte de ce dont il sera question ici, c'est-à-dire du dispositif d'exposition mis en place, tant par le muséographe que par le conservateur, parfois par l'architecte lui-même, le scientifique ou l'amateur. 
que merece destaque ou de esconder, silenciando o que poderia causar ruído na comunicação entre as obras e os visitantes da exposição. Desse modo, o designer é sempre instruído por briefing pelo curador, profissional que hoje é responsável pelo "desenho" das exibições.

Ainda se arrola como função do designer de exibições o desenvolvimento do projeto de comunicação visual da exposição o que engloba textos explicativos e impressos sinaléticos em paredes, etiquetas próximas das obras exibidas, material didático com informações mais precisas servindo de guia impresso para a exposição, as sinalizações de direção do espaço da exibição. Acrescenta-se também o material gráfico responsável pela divulgação da exposição de arte e pelos catálogos da exposição para veiculação da mídia.

O que se observa, porém, é que no Brasil nem sempre se conhece bem as competências que o Design de Exibições tem para oferecer ao processo de elaboração de exposições de arte e com isso, persiste uma lacuna sobre a aplicabilidade de suas potencialidades e sobre o âmbito de atuação do designer de exibições.

Uma consequência do mencionado desconhecimento é a falta de definição das funções a serem realizadas pelas diversas categorias profissionais que atuam na elaboração de uma exposição de arte, incluindo-se, entre elas, o designer de exibições.

O presente trabalho investigou inicialmente, por meio de leitura de bibliografia especializada sobre o tema e por meio de entrevistas a profissionais que atuam na área, como o Design de Exibições pode contribuir positivamente para o desenvolvimento das exposições de arte no Brasil. Investigou também se e como se manifesta seu ensino no país, conferindo-se atenção especial ao Rio de Janeiro. A segunda etapa da pesquisa se propôs a sugerir uma definição mais clara das funções a serem exercidas pelo designer de exibições de arte. Com isso, intenta-se distinguir o escopo de trabalho desse designer, do escopo de trabalho dos diferentes profissionais - curadores, arquitetos, museólogos, cenógrafos, artistas, dentre outros - que atuam no processo de elaboração de exibições de arte em museus e centros culturais do Brasil.

O Design de Exibições é um ramo do Design relativamente bem estudado e compreendido em diversos países. O Design de Exibições afirma-se internacionalmente como importante instrumento na construção de exposições de 
arte bem-sucedidas. Acredita-se que essa experiência estrangeira pode contribuir expressivamente para a melhor compreensão, divulgação, desenvolvimento e prática do Design de Exposições no Brasil, tendo-se como resultado um aperfeiçoamento de nossas exibições de arte.

A importância do Design de Exibições em exposições de arte montadas no estrangeiro como, por exemplo, no Reino Unido, Estados Unidos da América, Canadá, França, Itália, Alemanha, Singapura vem se afirmando nos séculos XX e XXI. Entretanto, pouco se conhece no Brasil sobre as possibilidades oferecidas pelo Design de Exibições aplicado a exposições de arte. A bibliografia nacional existente sobre o tema é escassa até o presente momento. As escolas e os cursos superiores de formação de Design nem sempre dedicam a atenção merecida ao tema do presente estudo, formando profissionais pouco familiarizados com o assunto.

Outro problema que resulta da pouca informação sobre o tema no Brasil é a falta de definição dos papéis a serem exercidos por cada uma das diversas categorias de profissionais que atuam no processo de elaboração de exibições de arte por aqui. Evidencia-se a necessidade de se desenvolver tal distinção de funções com a finalidade de permitir ao designer contribuir plenamente com suas capacidades especificas (utilizando-se de todo o seu arsenal teórico e prático de conhecimento), participando, com mais certezas e potencialidades, do processo de elaboração de exibições de arte no Brasil.

Os objetivos gerais desse trabalho são: a) avaliar se as competências do Design de Exibições aplicadas com sucesso a exibições de obras de arte no estrangeiro possuem verdadeiramente o potencial de facilitar a comunicação entre os objetos expostos, o espaço e o público visitante também em exposições realizadas no Brasil; b) avaliar se o Design de Exibições é aplicado no nosso país e ensinado em universidades e cursos de Design especialmente do Rio de Janeiro; c) definir as funções do designer de exibições com o fim de se distinguir seu papel daquele das demais categorias profissionais atuantes no processo de elaboração de exposições de arte. Os objetivos específicos são: a) analisar a aplicação do Design de Exibições a exposições de arte no cenário internacional; b) verificar se e como o Design de Exibições vem sendo considerado em exposições de arte do Brasil; c) averiguar quais são as funções do designer de exibições por meio de entrevistas com profissionais do Campo e pesquisa bibliográfica; d) estabelecer, pelo 
confronto entre entrevistas e a leitura de bibliografia especializada, quais são as habilidades especificas dos designers do ramo de exibições.

Assim, nosso trabalho de pesquisa formula as seguintes questões relacionadas ao Design de Exibições aplicado particularmente às exposições de arte: a) o que é isso que é o Design de Exibições?; b) tendo sido definido o objetivo da exposição de arte (que pode ser educacional, comercial, formador de gosto, por exemplo) como o Design de Exibições pode colaborar para que tal objetivo seja alcançado?; c) o Design de Exibições ainda é pouco conhecido e explorado no Brasil? Por quê?; d) o designer de exibições deve atuar na fase de concepção de exposições de arte assim como durante o processo de elaboração das mesmas? Por quê?; e) há funções relacionadas a exposições de arte que deveriam ser preferencialmente realizadas pelo designer de exibições?; f) quais são e por quê?

Para alcançar nossos objetivos formulamos duas hipóteses para serem testadas quanto à sua veracidade:

I) A aplicação do Design de Exibições às exposições de arte realizadas em museus e centros culturais no Brasil mostra-se essencial em razão de três de suas capacidades listadas a seguir: a) capacidade de conferir evidência aos objetos de arte dispostos no espaço dedicado à exibição; b) capacidade de comunicar informações sobre os objetos de arte expostos de maneira clara e dinâmica, facilitando a compreensão das obras por parte do público especializado ou não; c) capacidade de produzir material informativo útil para futuras consultas e pesquisas após o termino da exposição.

II) No Brasil, a definição do escopo de atuação do designer em exibições de arte realizadas em museus e centros culturais auxiliará para que ele participe do processo de elaboração de exposições de arte com o máximo de suas potencialidades.

Justificamos nosso trabalho pela importância que o Design de Exibições tem para o Campo da Arte, fato que vem se comprovando sistematicamente no cenário internacional. Como vimos, no Brasil, trata-se de um tema ainda pouco explorado quanto a sua teoria e prática. Dessa maneira, justifica-se a presente pesquisa pelo seu intuito de desvendar, no que se refere ao Design de Exibições, quais as competências profissionais do designer e se poderiam trazer benefícios quando aplicadas a exposições de arte em nosso país. 
Sabe-se que o Design de Exibições tem como parte de suas aptidões evidenciar ao máximo os objetos expostos e fazê-los comunicarem-se com seu público de maneira clara e dinâmica. Dessa maneira, justifica-se um estudo aprofundado sobre o emprego do Design de Exibições em exposições de arte pelo seu potencial de criar expografias habilitadas a permitir que os visitantes usufruam de uma rica experiência sensitiva além de transmitir informações amigavelmente, isto é, possibilitando ao público aprender ou usar algo ou alguma coisa, com facilidade ou intuitivamente.

Julga-se que haja necessidade de se definir quais funções devem ser exercidas preferencialmente pelo designer de exibições a fim de se potencializar sua participação no processo de elaboração de exposições de arte no Brasil.

Finalmente, justifica-se o presente estudo pela sua intenção de contribuir com a literatura pátria sobre o tema ainda insuficientemente explorado por nossos pesquisadores. Paulo Roberto Sabino escreveu a respeito do tema arquitetura de museus no Brasil e de suas exposições o seguinte:

No Brasil uma mudança na forma de apresentação de exposições tem início a partir dos anos 1990, com a realização das grandes mostras internacionais. Nos anos 2000 inicia-se a implantação de novos museus (ou a revitalização dos tradicionais), como o Museu da Língua Portuguesa e o Museu do Futebol com uso de tecnologias interativas e audiovisuais para a exposição de patrimônio imaterial. No contínuo desse processo, novos museus com arquiteturas contemporâneas serão inaugurados na cidade do Rio de Janeiro: O Museu da Imagem e do Som - MIS, com projeto do escritório de Nova Iorque Diller Scofidio+Renfro; o Museu de Artes do Rio - MAR dos arquitetos Thiago Bernardes e Paulo Jacobsen e um projeto do espanhol Santiago Calatrava, o Museu do Amanhã. Os dois últimos fazem parte do projeto de reurbanização e revitalização turística da zona portuária da cidade.

Apesar da notabilidade dos museus e de futuros projetos que serão realizados no país, ainda carecemos de uma bibliografia que dê conta das características brasileiras no que diz respeito à arquitetura e à expografia. Lisbeth Rebollo Gonçalves (GONÇALVES, 2004), Marília Xavier Cury CURY, 2005) e Sonia Salcedo Del Castillo (CASTILLO, 2008) são algumas autoras que preenchem essa lacuna, complementada por artigos e teses nas áreas de museologia, arquitetura e artes plásticas, que também tratam do assunto (SABINO, 2012: 49). (Grifo nosso)

O trabalho desenvolvido valeu-se de pesquisa de campo e de fontes bibliográficas de caráter hipotético-dedutivo. Comprovou e refutou as hipóteses formuladas ouvindo-se os relatos e as experiências práticas ou de uso de pessoas 
atuantes na área objeto de estudo, assim como através da literatura existente com vistas à fundamentação teórica do Campo. Nesse sentido, entrevistas foram realizadas com designers e profissionais brasileiros do Campo de exibições de arte em museus e centros culturais principalmente e eventualmente com alguns que atuam em bienais de arte também.

As entrevistas foram realizadas de maneira semiestruturada. Perguntas eram formuladas sem, contudo, limitar a troca de informações apenas aos assuntos sugeridos em pauta. Duas profissionais que não puderam ser entrevistadas participaram da pesquisa respondendo ao questionário a elas submetido. Esse questionário integra o apêndice da presente pesquisa. Tomando por base os dados obtidos e confrontando-os com a pesquisa teórica, buscou-se concluir quem e como se realizam na prática os aspectos físicos e visuais de exibições de arte no Brasil.

Quanto ao método bibliográfico utilizado, a presente pesquisa dispôs de livros, artigos, catálogos, anuários abrangendo tanto publicações nacionais como estrangeiras para que fosse possível um estudo comparado nas áreas do Design, da Museologia, da História da Arte e de suas das exposições, da Arquitetura, da Sociologia e da Psicologia. 


\section{O termo Design de Exibições e suas competências.}

Inicialmente cabe explicar porque se preferiu o uso da expressão Design de Exibições como tradução livre que se faz para o português da expressão em inglês Exhibition Design, embora também fosse possível ter-se optado pelo uso da expressão Design de Exposições. A escolha pela palavra exibições deu-se por motivo de sua sonoridade ser mais próxima à da referida palavra em língua inglesa.

Inúmeros debates e discussões vêm sido travados ao longo dos últimos tempos a fim de se encontrar a definição para Design de Exibição. A Society for Environmental Graphic Design (SEGD), renomeada Society for Experiential Graphic Design ${ }^{5}$ tem entendido o Design de Exibição como união de comunicação e ambientes. Essa definição aberta, eventualmente equivocada, possibilita

a contribuição de designers que anteriormente poderiam ter sido chamados de arquitetos, curadores, desenhistas industriais, historiadores, mas que com sua visão do design e habilidade para colaborar estão criando um campo distintamente único (ALGER \& DILWORTH. In.: LORENC \& SKOLNICK \& BERGER, 2007:06). ${ }^{6}$

Segundo pensa essa mesma organização, o Design de Exibições se desenvolve na direção da colaboração; do equilíbrio entre espaço, objeto e comunicação; da delicada integração da tecnologia e na compreensão do papel da audiência (ALGER \& DILWORTH. In.: LORENC \& SKOLNICK \& BERGER, 2007:06) ${ }^{7}$.

${ }^{5}$ A Society for Experiential Graphic Design (Sociedade para Design Gráfico Experiencial) parece existir desde 1973 e sua comunidade conta com mais de 1.800 membros, espalhados em 35 países segundo informado pelo site www.segd.org., acesso em 08/03/2017.

${ }^{6}$ Over the past few years, SEGD has been focusing on defining exhibition design as a merger of communication and environments. Defining it in this way opened the door to contributions by designers that at one time may have been called architects, curators, industrial designers or historians, but by their design vision and ability to collaborate are creating a distinctly unique field..

${ }^{7}$ This book is not meant to be the last word on exhibition design, but to serve as a clear statement about the nature of what the authors and SEGD consider to be the direction exhibition design is developing in. The focus is on collaboration; the balancing of space, object, and information; the subtle integration of technology; and the role of the audience. 
No nosso país, conforme mencionado pela arquiteta entrevistada Carla Juaçaba, o termo cenografia foi o inicialmente empregado para expressar essa atividade de se criar uma ambientação do espaço expositivo a fim de se contextualizar, de se promover uma narrativa para os objetos nele inseridos.

No livro Entre cenografias: o museu e a exposição de arte no século $X X$, Lisbeth Rebollo Gonçalves adota o termo cenografia referindo-se ao desenho espacial da exposição e explica sua preferência em detrimento ao termo museografia da exposição, pois considera haver na comunicação da exposição, uma aproximação muito direta com o que ocorre no teatro (GONÇALVES, 2004: 20).

Atualmente o termo expografia, tradução do termo francês expographie, e o termo projeto expográfico ou expositivo ganharam a preferência dos profissionais que trabalham nessa atividade no Rio de Janeiro. Em São Paulo, dá-se primazia ao uso dos termos projeto expositivo ou Design de Exposição conforme informado por Marcos da Costa Braga, Professor da Faculdade de Arquitetura e Urbanismo da Universidade de São Paulo (FAUUSP), por meio de comunicação escrita. O Professor acrescentou ainda a observação, com a qual se concorda plenamente, que a definição quanto à denominação da referida atividade ainda não goza de consenso e atribuiu o fato a própria origem da prática que possui raízes diversificadas em campos de conhecimento e profissões diferentes (BRAGA, 2017). O termo Exhibition Design (Design de Exibições ou Design de Exposições) vem sendo utilizado preferencialmente pelos países de língua inglesa.

Não se conseguiu concluir, na presente pesquisa, se os três termos diferem em algum aspecto entre si ou se, ao contrário, definem uma mesma atividade. Para quem entende haver uma diferença entre eles, a cenografia seria a que se relaciona à narrativa desenvolvida no espaço destinado à exposição considerando ensinamentos advindos das Artes Cênicas, a expografia aquela que ambienta o espaço expositivo considerando lições advindas da Museologia. Quanto ao Design de Exibições, deduz-se ser a prática que contextualiza os objetos expostos observando os ensinamentos advindos em grande parte do Campo do Design.

Concluindo da mesma maneira, transcreve-se texto

O museu contemporâneo é, cada vez mais, um espaço flexível que se modifica e se adapta a cada nova proposta curatorial; para isso, busca recursos em diferentes áreas do conhecimento. Os termos cenografia de exposições, arquitetura de exposições ou design de 
exposições são empregados para designar o trabalho de organização do espaço e das formas de expor um conteúdo. No entanto, do ponto de vista museológico, esses termos parecem carregar, exacerbadamente, as particularidades de suas origens, ou seja, teatro, arquitetura e design em detrimento do campo museológico. Outro termo, específico do campo museológico, criado por Desvallées em 1993 em substituição à "museografia", é "expografia" (Bary; Tobelem, 1998). Essa diversidade de termos demonstra que não há um consenso sobre como nomear a tarefa de dar forma expositiva a um determinado conteúdo (ROSSINI, 2012: 157).

Referindo-se ao termo expografia cunhado por Desvallées, Rossini entende:

O termo procura definir uma especificidade para os projetos de espacialização de uma exposição e as formas complementares de expor seu conteúdo, no entanto, parece não acrescentar nada que não esteja nos termos Cenografia de Exposições, Arquitetura de Exposições ou mesmo Design de Exposições (ROSSINI, 2012: 157).

O surgimento da disciplina Design de Exibições é razoavelmente recente na história do Design. Nasceu da necessidade, percebida pela indústria de produção de bens de consumo, de disseminar o conceito de "bom gosto", que pretendia influenciar o gosto da população desde o século XVIII. A prática de exibir publicamente esses bens ganhou regularidade nos séculos XIX e XX e sua importância se confere facilmente até hoje.

David Dernie, em sua obra "Exhibition Design", explica que a "disciplina de se exibir" apenas há pouco tempo começou a ser compreendida (DERNIE, 2007: 6). Para ele, realizar exposições tem sido cada vez mais reconhecido como uma significativa forma criativa de expressão. A História das Grandes Exposições em pavilhões na França e na Inglaterra evidenciam a importância conferida ao fenômeno a partir do final do século XIX, na Europa.

Dernie prossegue em seu livro, enumerando os aspectos que considera como as tarefas/missões primordiais do Design de Exibições. Afirma que, acima de tudo, o Design de Exibições considera o diálogo ente o objeto(s) a ser exibido e o espaço no qual o mesmo é apresentado: onde os objetos estão e como eles são dispostos vai determinar a natureza da mensagem que comunicam. Alerta ainda que diversos artistas têm se mostrado particularmente sensíveis à questão (DERNIE, 2007: 6).

A enumeração oferecida por Dernie parte, entretanto, de um pressuposto com o qual não se concorda: o de que um objeto de arte conversa com o espaço. 
Entende-se, diferentemente, que a obra de arte é disposta no espaço a fim de conversar com as pessoas. A definição proposta por Dernie considera o espaço e os objetos em "si mesmos", isto é, tecnicamente. O espaço e os objetos como se fossem autônomos ou independentes das relações sociais. Parece que a visão de Dernie emascula a dimensão humana ou social do Design de Exibições, entendendo o público como parte do espaço.

A presente pesquisa, ao considerar o Campo do Design, se filia à corrente de que não existe separação entre os objetos exibidos e a significação social que eles possuem. Concordando-se com o pensamento expresso por Bourdieu na obra $A$ economia das trocas simbólicas e aplicando-o ao Campo do Design, acredita-se não ser possível entender-se a prática do Design (aqui incluída a do Design de Exibições) independente do contexto histórico e social que a envolve.

Em texto sobre o histórico das exibições de arte europeias escrito por Katharina Hegewisch, traduzido e publicado pela Revista da Escola de Belas Artes da UFRJ em 2006, a autora ensina que:

A mise en scène, a disposição e a sucessão de objetos expostos sempre procurou influenciar o comportamento receptivo do espectador. A apresentação das obras incentivava as reações explícitas do público, fossem elas de ordem ativa ou passiva, críticas ou simplesmente curiosas - a exposição de arte sempre procurou provocar. E, até nossos dias, nunca foi questionado em seu princípio o fato de que a arte possa ser um veículo próprio à "elevação moral" da comunidade. A arte, desde sua origem, foi compreendida como a quintessência da verdade, do belo e do bem, e, mais tarde, como expressão do verdadeiro, do vivo e do autêntico, do único e do falsificado, do que é socialmente pertinente e progressivo (HEGEWISCH, 1998, In.: Revista do Programa de Pós-Graduação em Artes Visuais EBA, 2006: 188) .

Assim, a prática do Design e, consequentemente do Design de Exibições, é no presente trabalho entendida como resultante da produção ou construção de um arbitrário cultural, de uma noção ou convenção política entre as noções ideológicas contidas no briefing ou na "vontade" do curador, a recepção e os agentes de legitimação.

Não se compartilha, portanto, das seguintes concepções porventura defendidas por outras correntes: i) a de que o Design de Exibições teria por competência solucionar "problemas técnicos"; ii) que tais problemas devam ser resolvidos pelo intermédio de apenas um dado profissional que possua uma formação teórica ou um conhecimento técnico específico. 
Acrescenta-se, porém, que é preciso entender que esse "arbitrário cultural" é dinâmico historicamente. O que vale hoje, não valeu ontem e necessariamente não valerá amanhã.

Segundo Dernie, as exposições são tradicionalmente divididas em culturais ou comerciais, podem ser tanto permanentes como temporárias e são realizadas em diversos tipos de espaços. Embora existam tais classificações, as fronteiras entre elas se mostram menos nítidas atualmente. Técnicas e imagens que costumavam informar exposições de galerias comerciais, eventos de marcas empresariais ou da indústria do lazer passam a fazer parte de exposições em museus de arte. São atitudes que ambicionam reforçar a importância que se confere atualmente à competência das exposições de comunicar (DERNIE, 2007: $6)$.

Seja em exibições de museus como em espaços de vendas, feiras, quiosques de informação, eventos de entretenimento, o Design de Exibições busca criar experiências em tempo real, utilizando espaço, movimento e memória para facilitar uma comunicação em múltiplas camadas (LORENC \& SKOLNICK \& BERGER, 2007:09). Qualquer que seja o tipo de exibição em que tal competência é empregada, os designers de exibição trabalham em equipes multidisciplinares juntamente com seus clientes para ajudá-los a contar histórias para a plateia almejada (LORENC \& SKOLNICK \& BERGER, 2007:09). Eles conferem uma forma física ou concreta a uma experiência evanescente garantindo que as desejadas mensagens sejam apresentadas de forma a mais convincente e compreensível. Promete-se criar ambientes que comunicam. ${ }^{8}$

Segundo opinou Carla Juaçaba durante entrevista, emprega-se o Design de Exibições em exposições de arte como um tipo de narração, de interpretação partindo-se da noção de que há que contar alguma coisa, mesmo que a obra fale

${ }^{8}$ From museum exhibitions, retail spaces, and trade shows to themed entertainments, information kiosks, visitor centers, World's Fairs, and expositions, exhibition design involves itself in creating experiences in real time, utilizing space, movement, and memory to facilitate multilayered communication. In whatever type of venue or situation their skills are engaged, exhibition designers work in multidisciplinary teams with their clients to help them tell their stories to their desired audience. They physically shape the experience [...] to ensure that the intended messages are delivered in the most compelling and meaningful way. LORENC; SKOLNICK; BERGER. 2007: 8. 
por si mesma. ${ }^{9}$ Para ela, o Design de Exibições é a consequência de uma narrativa.

A presente pesquisa recorta suas atenções ao fenômeno do Design de Exibições aplicado às artes plásticas exibidas em museus de arte e em centros culturais. $\mathrm{O}$ artigo $3^{\circ}$, seção 1 do estatuto do Conselho Internacional de Museus (ICOM) com sede na França, adotado em 24 de agosto de 2007, durante a 22a Assembleia Geral ocorrida em Viena define:

Os museus são instituições permanentes, sem fins lucrativos, ao serviço da sociedade e do seu desenvolvimento, abertas ao público, que adquirem, preservam, pesquisam, comunicam e expõem, para fins de estudo, educação e lazer, os testemunhos materiais e imateriais dos povos e seus ambientes. ${ }^{10}$

Considerando-se que a definição de museu ainda gera grande controvérsia no Campo da Museologia e que a especificação de suas funções também não é pacífica na literatura sobre o tema (POULOT, 2005), decidiu-se adotar o conceito de museu desenvolvido por Teresa C. Scheiner por sua visão abrangente e não engessada da instituição. Pelo fato do mencionado debate fugir do escopo da presente pesquisa, o assunto não será abordado com a profundidade que merece. Segundo Scheiner:

O estudo da trajetória do Museu como representação nos mostra que ele vem sendo entendido simultaneamente como: espaço físico ou geográfico (território, espaço aberto ou edificação), contendo registros materiais (móveis ou imóveis) ou imateriais de patrimônio; espaço intelectual de criação e produção de cultura (incluindo-se aqui os espaços imaginários, que configuram o que se poderia denominar o 'museu interior'); espaço de exploração, investigação e experimentação; espaço de preservação de registros da memória humana e do planeta. Essas dimensões não são necessariamente consideradas ou trabalhadas em separado, podendo articular-se das mais diversas formas, de acordo com cada representação do fenômeno $[\ldots]$.

\footnotetext{
${ }^{9}$ Quanto à noção de que a obra pode falar por si mesma, pede-se vênia para discordar da visão expressada pela entrevistada por se acreditar, na presente pesquisa, que os objetos expostos sempre precisam ser contextualizados já que não se entende que possam ser autoexplicativos. Acredita-se que o objeto não produz conhecimento por si só.

${ }^{10}$ Un musée est une institution permanente sans but lucratif au service de la société et de son développement ouverte au public, qui acquiert, conserve, étudie, expose et transmet le patrimoine matériel et immatériel de l'humanité et de son environnement à des fins d'études, d'éducation et de délectation. Disponível em http://icom.museum/the-vision/museum-definition/, acesso em 02 de julho de 2016.
} 
Nada no Museu é, portanto, absoluto - e nem poderia ser, à luz do conhecimento contemporâneo, que a tudo relativiza (SCHEINER, 2008: 43-44). [...]

Entende-se que o museu de arte, por meio de exibições de seus acervos ou de obras de arte temporariamente emprestadas, busca expor ao público noções por vezes abstratas do mundo das artes plásticas que informam pinturas, esculturas, perfomances, instalações, vídeos. A reação do visitante poderá ser apenas contemplativa ou também participativa se assim for incentivado pela instituição, hipótese em que a própria obra de arte pode ser entendida como de autoria coletiva. O público atua na sua construção durante a visitação ao espaço de exibição.

Essa prática de articular objetos/imagens, espaço e visitantes é defendida pela museologia contemporânea e vem sendo observada por alguns teóricos que pensam o Design de Exibições, a fim de colaborar com a difusão dos conceitos e do conhecimento sobre arte ao público, facilitando a visitação e sugerindo-lhe significado. Essa comunicação além dos muros acadêmicos entre o museu e seu público tem o potencial de influenciar o cotidiano e as formas de percepção dos cidadãos (GONÇALVES, Prefácio. In.: SANTOS, 2006).

A articulação acima descrita é corroborada e explicada de maneira irretocável pela professora de Museologia da UNIRIO Helena Cunha de Azeda em artigo que conta com a colaboração de seus alunos:

Os projetos de exposição de acervo museológico têm, entre outras preocupações, a de decidir sobre a disposição de objetos bidimensionais e tridimensionais dentro das galerias, de modo que o posicionamento escolhido colabore para atrair a atenção do observador sobre eles, criando condições para que, por intermédio de uma experiência agradável, se concretize uma comunicação significativa desse acervo com o público. Indissociável da materialidade dessas obras está a ideia que delas é extraída pelo visitante da exposição, que as percebe pela visão platonista do objeto como projeção de saber ou pela visão aristotélica do objeto como experiência do sensível (AZEDA, 2011: 6).

Parece que David Dernie se filia a noção acima descrita da percepção do objeto exposto como fonte de saber. Para o autor, no cerne de toda exposição se situa a noção de comunicação. O conteúdo das obras e as suas possíveis interpretações didáticas devem ser articuladas por meio de uma sequência clara de relações espaciais (DERNIE, 2006: 6). Dernie esclarece que por meio de 
exposições, artefatos são reinterpretados e traduzidos por intermédio de seus novos contextos em si mesmo, isto é, que a exibição é, ou deveria ser autoexplicativa. Exemplifica que a escala, a cor, os materiais, a iluminação, os sons e os desenhos gráficos vão afetar a forma pela qual aquilo que é exposto se comunica com o visitante: a percepção pelo visitante do objeto em exibição mudará de acordo com seu contexto e apresentação.

Nesse ponto, cabe lembrar que a adição de elementos gráficos não garante necessariamente uma comunicação eficiente ou precisa, mas sim um resultado aberto onde é impossível determinar se aquilo que foi planejado ocorreu de modo eficaz, isto é, se o processo de comunicação se realizou como desejado. Pode-se afirmar que houve comunicação, mas não se pode afirmar que tipo de comunicação de fato aconteceu.

Nesse mesmo sentido de não se ter certeza sobre que tipo de comunicação houve realmente, Nelson Sanjad e Carlos Roberto F. Brandão afirmam que No Brasil, os estudos sobre a concepção de exposições se resumem a algumas poucas experiências (SAJAD \& BRANDAO, 2008). Prosseguem descrevendo algumas pesquisas sobre exposições em museus de ciências desenvolvidas em âmbito nacional por Martha Marandino. Em uma delas, a pesquisadora

analisou a construção do discurso expositivo em museus de ciência, entendido como o conjunto de elementos (objetos, textos, vitrines, imagens, iluminação, modelos, réplicas, etc.) articulados em um determinado espaço, repletos de significados e portadores de uma intenção. Segundo a autora, no processo de construção desse discurso, saberes de diferentes naturezas (senso comum, científico, museológico, comunicação, educação e outros) confrontam-se e são transpostos em uma síntese museográfica. O saber científico, geralmente o saber de referência em museus desse gênero, é recontextualizado e transformado por outros saberes e também pelas disputas no interior do museu e pelas especificidades de tempo, de espaço e do acervo (SAJAD \& BRANDAO, 2008: 31).

Assim, os autores tecem alguns pontos que acreditam não terem sido abordados nas pesquisas que citaram, dentre elas, a da transmissão clara, evidente dos propósitos da exibição para os visitantes do museu. Acredita-se que essas questões são aplicáveis também para exibições em museus de arte:

Apesar de bem conduzida, a pesquisa não explorou o ponto central em discussão nesse trabalho, diretamente relacionado à primeira etapa, que pode ser resumido em uma pergunta feita de diferentes maneiras: qual a relação entre os temas abordados e os objetivos do museu, ou por que os temas foram escolhidos pelo museu ou, ainda, 
que tipo de valor, leitura ou visão de mundo o museu quer afirmar, apresentando explicações científicas para fenômenos naturais, perceptíveis pelo senso comum? Essa não é uma questão simples, pois, do contrário, as mostras poderiam prescindir do museu e serem montadas em um shopping center, sem grandes prejuízos para as expectativas dos idealizadores. $\mathrm{O}$ que fez, portanto, aquelas exposições serem consideradas importantes para aquele museu? As razões certamente existem e podem até ser deduzidas pelos leitores, mas foram manifestadas nas exposições e ficaram claras para o público? Infelizmente, por diversos motivos, os museus brasileiros não incentivam esse tipo de pesquisa. Não há dados disponíveis, portanto, para comparações e análises (SAJAD \& BRANDAO, 2008:32). (Grifo nosso)

Citando-se Dernie: em contraste, o que o museu faz é altamente construído: ele limpa o espaço e faz comentários em objetos - o que, de repente cria um novo valor em razão do 'construído' - em razão de como eles são contextualizados (Dernie, 2007: 06). O autor informa ainda que a forma de exibir varia conforme a natureza e o conteúdo da coleção e que as abordagens vêm se modificando nos museus de arte, com o passar dos séculos.

Contrariamente, abordando-se o objeto exposto como um veículo para uma experiência do sensível, lembra-se que também a necessidade de se possibilitar a mera contemplação do que se expõe merece ser considerada quando da elaboração do projeto de exibição de obras de arte. A noção idealista, neokantiana, fundamento romântico da arte pela arte, pela qual a arte é uma experiência cujo fim seria meramente a contemplação gratuita, foi prestigiada no decorrer dos séculos XVIII, XIX, XX e até os dias de hoje pela prática expositiva em museus. Dada a sua importância histórica e o apelo que ainda exerce em parte significativa dos visitantes de museus de arte, acredita-se que deva permanecer sendo observada sempre que possível, pensando-se naqueles que vão a exposições de artes plásticas apenas para "mergulhar" em um ambiente diverso daquele vivido na realidade cotidiana.

A tentativa de se definir as competências do Design de Exibições mostra-se uma tarefa arriscada. Assim pensam Lorenc, Skolnick e Berger. Os autores afirmam que como a prática evolui constantemente, sua conceituação torna-se difícil. Afirmam que no caso do Design de Exibições, fala-se de um modo de comunicação que tem significados diferentes conforme o período de tempo considerado, que permanece se modificando e expandindo sua atividade e que, de 
fato, não é nem mesmo universalmente aceito como uma disciplina (LORENC \& SKOLNIC \& BERGER, 2007: 12).

Mas os autores acreditam ser possível observar-se que as exibições, que nos seus primórdios eram dirigidas para os ricos e para a elite intelectual, democratizaram-se com o passar do tempo, gradualmente incluindo pessoas das mais diversas camadas sociais. Outra evolução observada pelos autores diz respeito ao alargamento do vocabulário relacionado ao Design de Exibições. Agrega-se a inicial exibição estática dos objetos a preocupação com a interpretação e com a explicação didática, com as possibilidades de interatividade física ou eletrônica, com as apresentações multimídias, com a arquitetura, com o teatro, com a dança e com as artes performáticas. Observam ainda que o público começa a perceber o importante papel desempenhado pelo Design para o sucesso da experiência da visitação, ou como foi já dito em outras palavras, para torná-la "amigável". As universidades (estrangeiras) respondem oferecendo programas de Design de Exibições; publicações criticam a qualidade do design de determinada mostra; museus, dentre outros lugares de encontro público, recorrem ao Design de Exibições a fim de alcançar e alargar seus objetivos (LORENC \& SKOLNIC \& BERGER, 2007: 12).

Segundo Lisbeth Rebollo Gonçalves, a cenografia serve como facilitadora para a experiência estética e pedagógica (no sentido de apreensão dos conteúdos relacionados aos objetos expostos) dos visitantes. Ela engloba múltiplos recursos, quais sejam; documentais, desenho do espaço, uso da luz e da cor (...), recursos sonoros e outras tecnologias (GONÇALVES, 2004: 37).

Rossini no texto que abaixo se transcreve utiliza o termo cenografia. Lembra-se que o próprio autor entende que quanto ao conteúdo, o termo cenografia não difere do termo design de exibições. Entende-se que o trecho descreve com maestria as competências do Design de Exibições que, além de sua dimensão decorativa, organiza o espaço expositivo a fim de torná-lo não apenas esteticamente agradável, mas também condutor de uma narrativa. Essa narrativa busca conferir um contexto aos objetos (de arte ou não) exibidos, conferindo-lhes um dado sentido que se espera seja compreendido pelo visitante.

Em "La Muséologie, histoire, développements, enjeux actuels", Gob e Drouguet (2010) reconhecem que é comum a cenografia ser considerada como um elemento puramente decorativo. $\mathrm{O}$ aspecto decorativo da cenografia é importante porque torna a visita de uma 
exposição agradável, aumenta o interesse e a atenção do visitante. No entanto, dentro de um projeto museográfico, a função da cenografia ultrapassa seu aspecto puramente decorativo. A exposição é uma mídia em três dimensões que se oferece para ser percorrida sensivelmente por cada um dos visitantes e cujo discurso se constrói no espaço. Cenografia traz a dimensão conceitual do espaço, propondo ritmos e atmosferas geradas pela organização do espaço, da iluminação e do som (ROSSINI, 2012: 162).

Como disciplina, Dernie explica que o Design de Exibições se localiza em algum ponto entre a arte, a arquitetura, o design e a comunicação (DERNIE, 2007: 06). Segundo pensa, o Design de Exibições se preocupa com o planejamento de espaços interpretativos. Tal planejamento deve seguir um processo dialético no qual se desenvolve um diálogo entre técnicas retóricas verbais-conceituais e visuais-representacionais, tendo-se por foco o indivíduo quanto à suas capacidades perceptivas intelectuais e físicas (DERNIE, 2007: 06).

A exibição de objetos de arte em museus tem por finalidade criar um espaço que, pela distribuição de objetos intencionalmente organizados para produzirem um sentido, comuniquem mensagens e/ou estimulem sensações no público. Expor a obra de arte no museu implica torná-la pública, possibilitando que seja vista, analisada e compreendida por pessoas de perfis diversos. A exibição se mostra como uma mídia eficiente de comunicação entre museus e público a fim de transmitir informação, conhecimento e proporcionar lazer. 


\section{Origens do Design de Exibições.}

Tentar traçar as origens e a história do Design de Exibições não é tarefa fácil. O Design inclui-se como disciplina das chamadas Ciências Sociais. Como em relação a qualquer disciplina, costuma ser tarefa difícil definir-se seu local ou sua data precisa de surgimento. Geralmente ideias e práticas surgem em diferentes sociedades simultaneamente já que nascem de necessidades humanas e de respostas dos homens a fatores externos (LORENC \& SKOLNICK \& BERGER, 2007: 12). Assim cabe a pergunta: por que o Design de Exibições surgiu, quando e onde? A quais necessidades sociais ele busca atender?

Respondendo-se à questão do porquê do surgimento do Design de Exibições, acredita-se que essa disciplina do Campo do Design guarda relação direta com a necessidade das sociedades europeias maquinizadas do século XIX (destaque para Inglaterra e França) de ter seus produtos, agora compreendidos dentro de uma nova perspectiva, isto é, como mercadorias,expostos a uma grande quantidade de pessoas e de forma próxima, direta a elas. Logo, esses objetivos poderiam ser alcançados por meio de exibições públicas. Essa abordagem mais íntima intentava, além da ampla divulgação desses bens industriais produzidos em larga escala, influir decisivamente no gosto e nos desejos de consumo da população da época. Tal como ensina Forty, $O$ design altera o modo como as pessoas veem as mercadorias (FORTY, 2007: 20).

No século XIX, em alguns países da Europa ocidental, se observou um período de transição, com profundas transformações na forma de produção de bens para consumo. De forma contínua e progressivamente se passava de uma sociedade baseada na produção manufatureira para uma nova sociedade baseada no meio de produção industrial capitalista. Essas populações se viram, em um curto espaço de tempo, testemunhas de uma produção de bens em larga escala. Esse salto produtivo demandava a criação de um mercado consumidor robusto o que justificou que, a partir da Revolução Industrial, a população passasse a ser estimulada a consumir tais bens. 
Quanto mais se produzisse, mais a indústria venderia seus produtos. Assim, baseados na crença de uma produção infinita de bens e serviços, assim como, de progresso econômico e igualdade social ${ }^{11}$, fez-se urgente o desenvolvimento de uma prática eficaz de divulgação dos mesmos. O intuito de tal divulgação não era apenas o de tornar o bem industrializado conhecido ao máximo de seu público potencial, mas também, incutir no imaginário popular o desejo pela posse desses bens, graças às suas prometidas potencialidades de gerar mais bem-estar ou mais qualidade na vida de seus compradores. Como desenvolve Adrian Forty (FORTY, 2007), a ideia do progresso advindo da industrialização exerce sobre a população um apelo ao mesmo tempo de atração e de repulsa, gerando resistência às novidades indesejadas.

Mas é uma peculiaridade do capitalismo que cada inovação benéfica traga também uma sequência de outras mudanças, nem todas desejadas pela maioria das pessoas, de tal modo que, em nome do progresso, somos obrigados a aceitar uma grande quantidade de novidades a ele relacionadas e possivelmente indesejadas (FORTY, 2007: 19).

[...] uma vez que qualquer produto bem-sucedido deve superar a resistência à novidade, parece ser um axioma que os produtos do capital industrial busquem criar aceitações das mudanças que provocam. Entre as maneiras de obter essa aceitação, o design ${ }^{12}$, com sua capacidade de fazer com que as coisas pareçam diferentes do que são, foi de extrema importância (FORTY, 2007: 20).

O Design de Exibições é um ramo do Design que ambienta o espaço expositivo visando evidenciar ao público os objetos em exposição, colocando-o frente a frente com os produtos. Ainda, o Design de Exibições intenta evidenciar, de forma clara e atrativa, as características e qualidades dos objetos em questão demonstrando ao consumidor seus benefícios. Sua importância se caracterizou como fundamental com o crescimento da produção de bens industriais não

11 É preciso lembrar que a burguesia revolucionária propunha igualdade, fraternidade e liberdade, mas que tais pressupostos políticos ou ideológicos não foram necessariamente postos em prática quando da derrubada de governos monárquicos absolutistas europeus.

12 O termo design que consta da tradução do texto original do mencionado autor deve ser entendido como desenho industrial quando se referir à prática realizada nos séculos XVIII e XIX. 
essenciais, geradores de mudanças nem sempre benéficas ao indivíduo e desejadas pela sociedade.

Responde-se, portanto, à pergunta de quando nasceu o Design de Exibições adotamos nesse trabalho uma visão historicista do processo de surgimento de uma ciência ou disciplina. Partindo-se do pressuposto de que nada que o homem cria surge de um instante para o outro e isoladamente de um contexto social, concordase com a ideia de que as ciências sociais surgem de um complexo conjunto de experiências, pesquisas e teorias que são levantadas no decorrer do tempo, pela observação e trabalho de sucessivas gerações. Todo saber humano relaciona-se a um pré-saber (JAPIASSU, 1991:18). Em seu livro Introdução ao pensamento epistemológico, Hilton Japiassu escreve:

Antes do surgimento de um saber ou de uma disciplina científica, há sempre uma primeira aquisição ainda não científica de estados mentais já formados de modo mais ou menos natural ou espontâneo. No nível coletivo, esses estados mentais são constitutivos de uma certa cultura. Eles constituem as "opiniões primeiras" ou pré-noções [...] (JAPIASSU, 1991: 17-18).

Assim, embora não se possa determinar o momento exato de surgimento do Design de Exibições, há autores que o percebem como uma prática iniciada a partir do final do século XVIII pelo menos na Inglaterra (ARTMONSKY, 2014: 75), mas que vem ganhando maiores contornos e definições no século XIX e no século XX. A História das Grandes Exposições em pavilhões na Inglaterra e na França evidenciam a importância conferida ao fenômeno a partir do final do século XIX, na Europa, sendo relevante mencionar que a partir de 1855, na exposição universal de Paris, foi aberto um pavilhão para as Belas Artes (SANTOS, 2017).

Essas grandes exposições ocorridas no decorrer dos séculos XVIII, XIX e XX na Europa e também pelo mundo afora não exibiam apenas produtos industrializados, mas também tinham o intuito de apresentar a produção dos artistas da época no que se denomina de Salões. A Academia Real de Belas Artes (Académie Royale des Beaux-Arts), instituição francesa fortemente vinculada à corte e à alta nobreza local, era responsável por organizar esses Salões de exposições de arte (Salon, pois se localizava no Salon Carré do Palais du Louvre) e o fazia clamando para si uma posição de autoridade no assunto. Cabia aos membros da Academia julgar quais artistas da Instituição mereciam ser agraciados 
com o Grande Prêmio de Roma $^{13}$ e que reuniam as qualidades artísticas consideradas essenciais para terem o privilégio de exporem suas obras nos Salões, que passaram a ser realizados a cada dois anos entre 1748 e 1795 (BOIME, 1987: 14). Segundo Albert Boime, o hábito de se realizar exibições oficiais de arte na França teve início antes mesmo do século XVIII, desde 1667, mas passou a ser cerimoniosamente apresentada a partir de 1725 no Salon Carré do Louvre, antes mesmo da reforma arquitetônica mandada por Napoleão. É de amplo conhecimento a enorme influência que a Academia exerceu em quase toda produção artística do período em questão.

A presente pesquisa não intenta apresentar um estudo aprofundado sobre os Salões europeus dos séculos XVIII, XIX e XX, muitos autores já trataram exaustivamente do assunto, dentre eles Angela Ancora Luz (2005), Ana Maria Tavares Cavalcanti (2015) e Katharina Hegewisch (1998). O que se busca é fazer uma respeitosa referência a importante origem histórica das exposições públicas de arte, demonstrando-se sua relevância para o desenvolvimento de uma teoria de bem expor obras de arte desenvolvida a partir do início do século XX e em construção até os dias atuais. Nessa pesquisa e atuação se situa o Design de Exibições de arte, objeto central de nosso estudo.

As exibições realizadas no século XX, tendo-se por foco na presente pesquisa as exibições de artes plásticas, impuseram novos paradigmas à prática, a partir de então por alguns considerada como uma disciplina.

No século XXI, as práticas consolidadas no decorrer dos séculos XVIII a XX vêm sendo revisitadas ou repensadas e o momento é de experimentação, tantas vezes auxiliada pela introdução da tecnologia informática. Nas palavras aqui traduzidas de David Dernie [...] a 'disciplina de exibição', expressão cunhada pelo crítico de arte Germano Celant, está apenas começando a ser

${ }^{13}$ Prêmio que era conferido aos artistas nos Salões anuais. Tratava-se de bolsa de estudos de arte em Roma, de duração de um ano, cujo objetivo era permitir ao artista agraciado aprender profundamente os fundamentos da arte a partir do estudo das obras dos grandes mestres do passado, pois a cidade de Roma era tida como uma espécie de guardiã da arte da Antiguidade Clássica, período histórico, desde o Renascimento, considerado como referencial para a produção artística, especialmente nos séculos XVI, XVII e XVIII e início do XIX. 
entendida. É multidisciplinar e suas fronteiras são complexas (DERNIE, 2006:6). ${ }^{14}$

Finalmente aborda-se a terceira questão elencada no início do presente capítulo que busca identificar o lugar de origem do Design de Exibições. Novamente, trata-se de tarefa cujos contornos são imprecisos. Compreendendo-se o Design de Exibições como um ramo do Design que, por meio da evidência conferida ao objeto exposto, auxilia a indústria a tornar um determinado bem (nas suas origens, um bem industrializado ou uma mercadoria) mais desejado e mais bem compreendido e aceitado por seu público, há que se pesquisar o tema de maneira imbricada como da origem do Design. Sendo o Design de Exibições um satélite/corolário do Design, torna-se indissociável e essencial o estudo em conjunto do local de nascimento de ambos.

Rafael Cardoso Denis escreve que existe uma diversidade de opiniões sobre a origem do Design. Há aqueles que definem o Design como o planejamento formal e construtivo para qualquer tipo de produção em série e, portanto, buscam a origem desta atividade na Roma antiga com as suas louças aretinas e suas armas padronizadas [...] ou na fabricação de azulejos quase idênticos na Europa da Idade Média ou ainda, na produção resultante do uso da prensa tipográfica (DENIS, 1996: 59).

Outros entendem a origem do Design como um fenômeno moderno, nascido no século XX. Divergem, entretanto, quanto ao local de seu aparecimento. Teria sido na Alemanha, pelos esforços de um grupo restrito de arquitetos, pioneiros de uma nova profissão ou nos Estados Unidos da América da década de 1930, quando o Design era compreendido como uma atividade profissional apta a revitalizar as vendas em queda em razão da Grande Depressão (DENIS, 1996: 59).

O presente estudo corrobora com a teoria de que o Design teria surgido com o advento da Revolução Industrial, após a segunda metade do Século XVIII, como uma necessidade naturalmente sentida pelos industriais para o incremento do consumo. Tais empreendedores perceberam que era vital a aceitação de seus produtos pela população para que a produção fosse vendida, trazendo os lucros

14 "[...] yet the 'discipline of exhibiting', a phrase coined by the art critic Germano Celant, is only beginning to be understood. It is multi-disciplinary and its boundaries are complex." 
almejados. O Design foi historicamente desenvolvido a fim de tornar os bens industrializados mais aprazíveis ao gosto de seus possíveis consumidores.

Tendo sido denominado Desenho Industrial em seus primórdios, concordase com o raciocínio lógico expresso por Denis de que evidentemente não pode existir Desenho Industrial ou Design sem indústria. Sabe-se que a indústria de produção em massa é um fenômeno datado a partir da segunda metade do século XVIII, presente inicialmente na Inglaterra (DENIS, 1996: 60) e após a segunda metade do século XIX também na França (FALCON, 1981). Posicionamento idêntico é adotado por Adrian Forty no capítulo Os Primeiros Designers Industriais de seu livro Objetos de desejo - design e sociedade desde 1750 (FORTY, 2007).

Ao longo dos séculos XVIII e XIX, o Desenho Industrial afirmou sua existência e importância na Inglaterra, na França, na Alemanha sem, contudo, possuir um estatuto próprio. A partir de 1919, com a criação da escola Bauhaus de Weimer, o Design passou a gozar de um estatuto legal próprio, institucionalizando-se. Considerado então uma disciplina a ser ensinada, o Design do século XX recrutava e formava alunos. Dirigentes dessa escola inicialmente criada na Alemanha brevemente se transferiram para os Estados Unidos da América, levando para o novo continente as teorias e os debates acerca da disciplina Design.

Tão complexa como a definição do local de surgimento do Design mostra-se a tentativa de se especificar o local de origem do Design de Exibições. Pode-se afirmar, porém, que na Inglaterra, berço da Revolução Industrial, havia a necessidade premente de se vender a produção industrial a um mercado disposto a consumir. Essa revolução que modificou progressivamente a forma de produção de artesanal para industrializada teve seus valores e ideais expandidos para outras nações europeias. A industrialização modificou não apenas a forma de produção dos bens postos indistintamente ao consumo como as relações sociais e a visão de mundo das populações das referidas sociedades.

Portanto, defende-se que o lugar do surgimento da prática (a partir do século XVIII) daquilo que atualmente se denomina Design de Exibições tenha sido a Inglaterra pelas condições que oferecia para tanto, no caso, a já avançada industrialização da produção de bens e a consequente criação de uma demanda de consumo no seio da população cada vez menos livre (JAPIASSU,1982: 18). 
Fortalece-se ainda a crença da importância da Inglaterra para o surgimento do Design de Exibições pela ideia defendida por alguns de que o Design teria surgido pelas mãos de Christofer Dresser, um escocês do século XIX com larga produção de projetos para indústrias e com passagem pela à época incipiente School of Design de Londres (DENIS, 1996: 60).

Defende-se ainda na presente pesquisa o entendimento de que o emprego do Design de Exibições aplicado a exposições de arte em museus, Salões de Arte e em exposições universais se evidenciou a partir do século XIX nos países industrializados europeus, nomeadamente Inglaterra e França. O modo como essa atividade era realizada desde então observou importantes modificações até os dias atuais (2017) e o seu alcance geográfico foi consideravelmente ampliado, temas que serão abordados no capitulo seguinte. 


\section{Comentários sobre as exibições de arte a partir do século XVII na Europa Ocidental.}

O presente capítulo não pretende explorar com profundidade o histórico das exibições de arte nos períodos moderno e contemporâneo europeu visto que tratados importantes já existem sobre o assunto ${ }^{15}$. Entretanto, a título de contextualização do processo de constante evolução observado na prática do Design de Exibições, entende-se relevante apresentar em linhas gerais as etapas progressivas da maneira de exibir arte que vigoraram na Europa Ocidental desde o século XVII.

Antes de se prosseguir, faz-se necessário definir o que vem a ser exposição. Recorre-se as definições oferecidas no livro Entre cenografias: o museu e a exposição de arte no século $X X$ de Lisbeth Rebollo Gonçalves que trata do assunto de maneira acurada. Inicialmente a autora lembra que a palavra exposição deriva do latim exponere que significa "pôr para fora", "entregar à sorte" (GONÇALVES, 2004: 13). Em seguida, explica que os dicionários conceituam exposição em termos muito gerais, como uma apresentação de algo que é dado aos sentidos do homem. O conceito abarca tudo o que se apresenta através da visão[...](GONÇALVES, 2004: 13).

A autora escreve:

A exposição se funda na presença de objetos que fazem sentido, num espaço que os torna acessíveis aos sujeitos sociais. Ela funciona como espaço de representação.

Pode-se, de imediato, depreender que a mise en scène da exposição tem papel fundamental no processo comunicativo de seus conteúdos. A exposição pode ser entendida como um processo de comunicação, uma mediação. Nesse sentido, ela implementa informações culturais voltadas para o visitante, para seu receptor. Ela é, sempre, uma "ativação" (GONÇALVES, 2004: 18).

A exposição de arte é uma apresentação intencionada, que estabelece um canal de contato entre um transmissor e um receptor,

${ }^{15}$ LUZ (2005: passim), CAVALCANTI (2015: passim) e HEGEWISCH (1998: passim). 
com o objetivo de influir sobre ele de uma determinada maneira, transmitindo-lhe uma mensagem (GONÇALVES, 2004: 29).

Talvez a forma mais tradicional de exibição tenha sido o gabinete de curiosidades, cômodos dentro de ricas casas particulares ou em palácios da nobreza, que emergiu no século XVII e que servia para possibilitar a exibição de objetos exóticos de todas as partes do mundo, colecionados geralmente pela nobreza europeia. Esses objetos, normalmente vários de um mesmo tipo, eram dispostos conforme uma organização pouco usual, geralmente buscando surtir no observador efeitos meramente estéticos. O grupamento dos objetos não seguia uma ordem científica, eram postos lado a lado por motivos de cor, materiais ou por possuírem a mesma função ou ainda por partilharem da mesma configuração formal, por exemplo (LORENC et ali., 2007: 13).

Apenas o próprio colecionador ou seus seletos convidados pertencentes às ricas famílias da época, poderiam visitar os objetos dispostos nesse espaço privado. O conceito de coleção aberta ao público ainda não vigorava. Esses ambientes organizados de forma hoje considerada esdrúxula tinham como um de seus intuitos criar uma apresentação impressionante de objetos exóticos ou grotescos segundo os padrões europeus da época. A exibição em museus e galerias de arte evoluiu dessas coleções a partir do final do século XVIII, quando algumas delas foram combinadas e organizadas para serem expostas ao público (HUGHES, 2015: 10).

Cita-se como exemplo o Museu do Louvre, em Paris. Construído ao final do século XII por ordem do rei Filipe Augusto (1165-1223), o castelo do Louvre era originalmente uma fortaleza militar cujo objetivo era reforçar a proteção da cidade de Paris. $\mathrm{O}$ edifício foi transformado em palácio real para acomodar, no século XIV, o rei Carlos V (1338-1380). Repetidas guerras afastaram os reis e sua corte de Paris, forçando-os a se instalarem em castelos do Vale do Loire. Embora palco de constantes obras durante reinados dos séculos XV e XVI, foi a partir do século XVII que o Palácio do Louvre passou a ser a residência de nobres, intelectuais e artistas que apresentaram ao rei um projeto de museu. Embora o rei Luís XVI tenha aprovado a ideia e iniciado os trabalhos de adaptação do prédio para essa finalidade, a Grande Galeria tornou-se aberta ao público apenas com o advento da Revolução Francesa, inicialmente exibindo em seu espaço as coleções reais. No período do governo imperial de Napoleão Bonaparte (1769-1821), o Louvre foi 
alçado ao patamar de grande museu, contando com o trabalho de seu primeiro diretor, Dominique Vivant Denon (1747-1825) que organizou as coleções, agora enriquecidas por doações privadas e por objetos confiscados durante as campanhas militares de Napoleão. ${ }^{16}$

As chamadas exibições públicas em museus e galerias de arte tiveram início a partir do final do século XVIII, com a queda ou enfraquecimento das monarquias absolutistas europeias e com o apogeu do pensamento iluminista. Muitas coleções privadas passaram a ser exibidas publicamente de maneira contínua. Cita-se a vasta coleção de obras de arte da família Médici, alocada na Galeria Uffizi em Florença com o objetivo de atrair visitantes. Geralmente palácios eram adaptados à nova finalidade de abrigar objetos para exibição pública e também museus ou galerias de arte guardavam esses objetos de valor e tinham o propósito de promover a educação de uma população letrada que se instruía a passos rápidos. A promessa de contribuir para o aprimoramento dessas pessoas era o aspecto central da exibição, permitindo-lhes compreender o mundo de uma maneira ampla e mais complexa (HUGHES, 2015: 11). Outro exemplo de palácio transformado no século XVIII em museu é o Hermitage, em São Petersburgo, que se inclui atualmente entre um dos maiores museus de arte do mundo (LORENC et ali., 2007: 14).

A primeira galeria pública de arte do Reino Unido chamava-se Dulwich Picture Gallery, situada na região sudeste de Londres na qual eram expostas pinturas que haviam sido adquiridas por dois comerciantes de arte a pedido de Stanilaus Augustus, rei da Polônia. Entretanto, com sua abdicação ao trono em 1795, a coleção permaneceu com os comerciantes que obtiveram o suporte necessário para expô-las publicamente. Essa galeria se tornou referência para arquitetos e designers no tocante a como um espaço dedicado à arte deveria parecer. Nessa galeria a luz do dia se fazia introduzir por cima, inovando a prática de iluminação em uma época em que, na maioria dos prédios, as pinturas ainda eram penduradas em paredes com janelas (HUGHES, 2015: 11).

Nos Estados Unidos da América, credita-se a Charles Wilson Peale o mérito de ter aberto o primeiro museu público do país em mil setecentos e oitenta e seis.

\footnotetext{
${ }^{16} \mathrm{https}: / /$ www.pariscityvision.com/pt/paris/museus-de-paris/museu-do-louvre/louvre-palaciovirou-museu. Acesso em 20/10/2016.
} 
Peale foi pioneiro em advogar a retirada das coleções de objetos, de arte ou não, da propriedade do governo, da Igreja ou de galerias reais para fazerem parte do acervo do museu, local onde se coleciona, conserva e se exibe cultura para todos (LORENC et ali., 2007: 16).

Não se pode deixar de mencionar que a Igreja Católica desempenhou durante muitos séculos o papel de patrona da arte de temática religiosa e desde eras remotas exibiu aos fiéis pinturas, esculturas, mosaicos, artefatos e ícones religiosos em suas paredes, altares, nichos. Ao final do século XVIII, a Igreja iniciou uma campanha para criar o que hoje se conhece como os Museus do Vaticano. Segundo Lorenc, Skolnick e Berger, esses museus tinham desde o início de sua concepção o objetivo de expor objetos de forma a aumentar sua grandeza, legitimando-os como importantes e significativas obras de arte, afirmando assim o enorme poder e a riqueza da Igreja como instituição. Os autores acreditam que em grande parte esse objetivo foi atingido por meio da escolha criteriosa quanto ao uso das cores, da ornamentação arquitetural e pelo emprego de nichos, criando forte impacto nos visitantes e conferindo importância aos objetos expostos. Enfim, parece ter havido a preocupação com o planejamento e a disposição das obras de arte no espaço, a fim de contextualizá-las e pô-las em evidência (LORENC et ali., 2007: 14-15).

Citam-se ainda os salões parisienses como importante marco da exibição de arte, realizados a partir do século XVIII e tornando-se notórios durante o século XIX. Segundo Sonia Salcedo Del Castillo:

Se toda obra é uma afirmação que só se revela quando abandona o isolamento do ateliê e se apresenta diante de outro sujeito, depreendemos que a autonomia do circuito artístico vincula-se à transmissão e à recepção de seus objetos, pois é exibindo-os que as ideias e convicções artísticas adquirem concretude (CASTILLO, 2008; 25).

A autora escreve que já os primeiros salões realizados no século XVIII atraíam um público amplo, aumentando assim o acesso à visibilidade da produção artística, algo decisivo para a concomitante desvinculação que se passou a observar entre a arte produzida no período e o gosto monárquico. Rompeu-se a subserviência do artista ao gosto do rei (CASTILLO, 2008; 26). A autora constata que essa nova realidade de independência do artista em relação aos padrões artísticos impostos pela nobreza europeia era possível graças à formação de um 
outro público de arte e graças à crítica impressa que nascia. Assim, enquanto julgamento público, aqueles salões tornavam-se um corpo regulador da arte e, exatamente por esse motivo, logo passariam a atrair os interesses da elite (CASTILLO, 2008; 26).

Referindo-se aos artistas do século XIX, a autora reflete sobre como eles influenciaram a maneira de se expor obras de arte. Nesse sentido, é de amplo conhecimento a discordância que alguns deles passaram a manifestar em relação às exigências impostas pela Academia de Belas Artes francesa para que obras pudessem participar dos salões de exposições. Surgem então os movimentos de vanguarda, a iniciar-se pelo grupo dos impressionistas, que organizam suas próprias exposições autônomas, apresentando obras e artistas recusados pelos salões oficiais. Castillo escreve:

Forjando a instituição de seu valor artístico no mercado, esses artistas produziram, paralelamente aos conceitos expositivos, mudanças significativas capazes de esclarecer não apenas as transformações ocorridas nas concepções de espaço e montagem, mas o próprio papel das exposições ao longo da história da arte (CASTILLO, 2008; 25).

Dessa forma, no final do século XIX, a verve da autonomia do circuito de arte estava lançada com os impressionistas, impulsionando mudanças significativas nas concepções expositivas. Ao opor-se frontalmente aos conceitos adotados nas montagens daqueles salões, os artistas se opuseram também ao gosto do público dominante. E, para atrair a esfera pública, deparavam gradativamente com a necessidade de desenvolver estratégias de montagem originais. Assim, as obras vanguardistas foram veiculadas sob critérios espaciais conceitualmente muito próprios (CASTILLO, 2008; 27-28).

Finalmente citam-se as feiras de exposições que se multiplicaram no século XIX, levando ao conhecimento e aceitação do público os produtos industrializados da época, prestigiando e promovendo as indústrias de alguns países da Europa. O grande marco se deu com a famosa Great Exhibition de 1851 de Londres, realizada no Palácio de Cristal. Esse importante evento é tido como responsável pelo início do movimento denominado World Expo, hoje gerenciado pelo International Exhibitions Bureau sediado em Paris. A receita arrecadada pela Great Exhibition foi investida na criação do museu The South Kensington Museum em Londres, hoje renomeado Victoria \& Albert. Sem objetivar o aspecto recreativo, esse museu foi criado com o intuito declarado de melhorar os padrões da manufatura e das artes aplicadas, servindo em seus primórdios como fonte de 
pesquisa para artistas, artesãos e manufaturas interessadas em aprimorar seus produtos (HUGHES, 2015: 13).

Algumas dessas feiras de exposições de produtos industrializados exibiam concomitantemente trabalhos artísticos. Foi o que ocorreu durante a Exposição Internacional de Paris de 1855. As obras de arte eram apresentadas em paralelo aos objetos industriais o que, segundo Castillo, dificultava a fruição e o julgamento estético das mesmas por parte do público (CASTILLO, 2008: 30). Essas exibições, embora apresentassem uma variedade de tipos de objetos e não apenas trabalhos artísticos, serviram ao propósito de popularizar a ideia da exibição pública para todos e podem ser consideradas como uma das pedras fundadoras do conceito de museus públicos (LORENC et ali., 2007: 16).

Sobre as exibições de arte nos séculos vinte e vinte um, pode-se dizer que além dos museus, centros culturais, galerias de arte, feiras de exposições, igrejas e templos religiosos, a arte passou a ter o espaço urbano e até mesmo regiões inóspitas do planeta como palco.

Também é indispensável mencionar-se a internet como plataforma de difusão da arte a um público cada maior. Há algumas décadas já se veicula pela internet imagens digitalizadas dos acervos dos principais museus de arte do mundo. Outra novidade relativamente recente diz respeito à existência de museus unicamente virtuais. O museu ubíquo torna possível a visitação de seu acervo a qualquer tempo e em qualquer lugar, bastando para tanto que a pessoa se conecte a um computador interligado a web (URURAHY, 2013: 16).

A presente pesquisa não pretende avançar no tema já que o recorte de sua atenção diz respeito ao Design de Exibições aplicado a museus de arte e centros culturais. Entretanto, faz-se alusão ao assunto em razão da importância que a tecnologia tem assumido na divulgação e na popularização da arte nos dias atuais.

O início da prática profissional do Design de Exibições em museus de arte exigia superar desafios de natureza técnica e úteis à exibição. Quanto à iluminação dos prédios e dos objetos expostos, vivia-se em uma época na qual ainda não se empregava a eletricidade para iluminação. A iluminação a gás, ainda que fosse um salto tecnológico em relação ao que existia antes, era carente de fontes confiáveis. Essa condição levou os designers a favorecerem a infiltração zenital da luz natural nas galerias destinadas às exposições. Dessa maneira, potencializava-se o uso da superfície das paredes, agora mais livres para exibirem objetos. Vitrines 
expositivas eram geralmente posicionadas abaixo dessa luz zenital para maximizar o uso da iluminação natural e o átrio central das construções era deixado vazio, permitindo a distribuição da luminosidade nos níveis mais inferiores do prédio (HUGHES, 2010: 13).

Quanto aos modos de exibição, vitrines de vidro de variados tamanhos e com grossas molduras de madeira se tornaram frequentes em museus. Garantiam segurança e proteção dos objetos contra furtos e avarias. Entretanto, o vidro muitas vezes atrapalhava a visão dos objetos exibidos no interior das caixas se a iluminação natural do ambiente fosse fraca. Ele também criava uma barreira psicológica entre o visitante e o objeto (HUGHES, 2010: 13).

Além das dificuldades de ordem técnica que dificultavam ao visitante tirar o máximo proveito das exibições, havia ainda a atitude pouco prestativa dos organizadores (ou curadores) da época que se viam mais como guardiães das coleções que lhes eram confiadas do que como agentes facilitadores da visitação pública do acervo. Essa atitude se refletia na atmosfera reverentemente silenciosa e nas barreiras impostas entre os objetos e as pessoas.

As exibições costumavam apresentar muito mais objetos em um dado ambiente ou dentro das vitrines de exibição do que seria considerado adequado para os padrões dos séculos XX e XXI. Essa maneira expositiva dificultava a visitação do observador e sua compreensão dos assuntos aos quais não estava versado. No tocante as pinturas, elas eram penduradas umas acima das outras até atingirem a altura máxima das paredes, muitas vezes impossibilitando a observação acurada dos trabalhos (HUGHES, 2010: 13).

Por fim, medidas de conservação do acervo que hoje são consideradas primordiais tais como controle da temperatura, umidade relativa e poluição do ar não eram prevalentes à época (HUGHES, 2010: 13).

A partir do século XIX o conceito de exposição se constrói de maneira mais sistemática acompanhando uma aprofundada pesquisa científica das coleções, mudando de feição no decorrer do tempo. Foi o momento em que se desenvolveram os procedimentos de taxonometria. Também há que se mencionar que a arte abstrata produzida no final do século XIX e início do século XX levou ao surgimento de uma nova estética que serviu como ímpeto para que as exibições de arte fizessem parte dessa inovadora experiência. O espaço expositivo das exibições desse período precisava guardar uma ressonância com as obras 
expostas, deixando de servir apenas como um local para a catalogação das mesmas. Os mencionados procedimentos de taxonometria foram substituídos pelo julgamento estético individualmente manifestado pelo curador e pelo designer (DERNIE, 2007: 9).

Segundo constata Lisbeth Rebollo Gonçalves, existe uma disposição expositiva de arte em museus que é característica do século XX. Inicialmente observam-se paredes brancas (o cubo branco) e uma nova maneira de distribuição das obras no espaço das salas. Especialmente após 1990, surgem novos dispositivos de apresentação, como a tendência à teatralização pelo uso de cores e pelo recurso à ambientação, algo bem diverso do observado durante o século XIX. Conforme a autora, a maneira usual de se exibir arte no século XIX e que prevaleceu até 1920

[...] ocupa todo, ou quase todo, o espaço da parede disponível para a apresentação das obras bidimensionais. Com relação à escultura, amontoam-se os pedestais contendo obras no espaço da mostra, quer próximo às paredes, quer no meio das grandes salas (GONÇALVES, 2004: 18).

Novamente Hughes ensina que as modernas técnicas de exibições em museus são largamente influenciadas pelos movimentos de arte e de design do início do século XX, especialmente pelo desenvolvimento da arte abstrata e por novos princípios defendidos por artistas e designers de vanguarda, muitos deles provenientes da Bauhaus, entre os anos de 1919 e 1937. Ele explica que esses novos princípios levaram designers a repensar os elementos de design e a reinterpretar espaços de prédios. Ambientes expositivos foram reconcebidos de maneiras diferentes por Surrealistas, Futuristas e Construtivistas. O autor escreve ainda sobre como artistas como Duchamp foram pioneiros no desenvolvimento da modalidade artística denominada instalação que considera o espaço expositivo como parte da obra, ao invés de apenas um envoltório onde o trabalho é disposto (HUGHES, 2010: 14). Duchamp e Philip Johnson também elevaram objetos industriais ao status de trabalhos artísticos expondo-os nas galerias dos museus da mesma maneira como eram exibidas obras de arte (HUGHES, 2010: 15).

Hughes relembra as inovações promovidas nas décadas de 1930 e pelo Modern Movement no Museum of Modern Art (MoMA) de Nova Iorque, inspirados pelos princípios da Bauhaus alemã. Das diversas experiências realizadas em busca de uma nova maneira de expor arte, a que talvez tenha 
deixado um legado mais duradouro foi também a mais simples. Alfred Barr, diretor do museu no período, foi o pioneiro a montar exibições em cujas pinturas eram penduradas nas paredes respeitando a espaços regulares entre elas e reservando uma borda de espaço vazio ao redor de cada um dos objetos expostos. A prática de se pendurar quadros um acima do outro até o final das paredes das galerias foi eliminada. Essas paredes passaram a ser pintadas de cores neutras, inicialmente de bege e posteriormente de branco. Todas as exibições montadas por Barr seguiam essa mesma organização espacial. Visitantes eram encorajados a ignorar a história do artista assim como o contexto social que vigorava quando da produção da obra de arte e a considerar a arte como um objeto autônomo. Esse estilo de exibição de arte que persiste até os dias de hoje era extremamente inovador para sua época (HUGHES, 2010: 16).

Dernie escreve que a estética expositiva empregada pelo historiador e diretor do MoMA Alfred Barr obteve tamanha repercussão que veio a ser afirmar durante muito tempo como método convencional para se ambientar exposições de arte. As paredes brancas confeririam neutralidade à mostra. $\mathrm{O}$ chão de madeira polida e as superfícies minimizadas completavam o conceito minimalista do cubo branco que a princípio não criava interferências à apreciação das obras expostas. Criava-se um tipo de espaço no qual se buscava transcender à especificidade de tempo e de lugar (DERNIE, 2007: 9).

Hughes ressalva, entretanto, que as atuais práticas não representam necessariamente melhorias na maneira como os objetos são dispostos em museus ao seu público. O autor faz uma ressalva ao fato de que muitas vezes pinturas e esculturas são apresentadas em um ambiente que não guarda qualquer relação com o contexto para o qual foram criadas. Cita como exemplo as pinturas religiosas, mais especificamente os trípticos que ornavam altares das igrejas durante a Idade Média e o Renascimento e que quando transportados para as galerias dos museus contemporâneos parecem estranhamente fora de lugar, totalmente descontextualizados (HUGHES, 2010: 13 -14).

Klein explica que o objeto exposto em um museu, seja uma obra de arte ou não, adquire um conteúdo e um significado que não lhe eram intrínsecos originalmente. Ao ser inserido na exibição, o objeto passa a ser reverenciado, considerado icônico. $\mathrm{O}$ autor acredita que as incongruências de tempo e de espaço que surgem pela presença do objeto no museu podem ser mitigadas em certo grau 
pela alteração do ambiente expositivo. Segundo ele, o design pode providenciar esse contexto e ajudar a reduzir as barreiras para a apreciação e compreensão por parte do visitante. Afirma que o grau em que isso pode ser feito é uma questão de julgamento e de gosto, que depende dos objetos expostos e do tema da exibição, sendo limitado por questões de orçamento e de tamanho e configuração das galerias (KLEIN, 1986: 69). O designer tem a sua disposição o uso das cores e da iluminação, a adição de elementos evocativos ou detalhes que projetam de forma dramática ou sutil o contexto apropriado e finalmente, replicar totalmente ou em parte o ambiente no qual o objeto exposto estava inserido originalmente (KLEIN, 1986: 69).

Sobre a questão da descontextualização do objeto de arte e do artefato histórico exposto no museu contemporâneo, David Dernie considera que o problema não pode ser resolvido de todo apenas pelo aporte de elementos de design. Ensina que a abordagem quanto à interpretação do conteúdo irá invariavelmente refletir o caráter da instituição. Mas, ao mesmo tempo, a maneira como a exibição é estruturada deve facilitar a compreensão da narrativa almejada ou a associação visual determinada pelo curador e seu grupo de trabalho (DERNIE, 2007: 12).

Segundo o autor, a narrativa tem ocupado um papel central nas montagens de exibições atuais e ensina que ela se refere à abordagem de como se ordenar objetos no espaço de forma a que contem uma história. Nesse sentido, o Design de Exibição é frequentemente definido como narrativa. E o espaço narrativo diz respeito à contextualização do objeto exposto. Dernie prossegue explicando que espaço narrativo pode tratar da relação entre o objeto e o local em que é posto em exibição, ou da questão da luz e sombra, ou de reflexões e configurações que evoquem correspondências visuais. Finalmente, Dernie lembra que atualmente há uma ênfase em se criar um fio narrativo que conduza a uma resposta emocional como componente chave da experiência do visitante. Para atingir esse objetivo, o Design de Exibições recorre ao uso de cores, de sons e de padrões de movimento lento ou rápido (DERNIE, 2007: 11-12).

Dernie, tal como Hughes, cita o trabalho inovador que foi desenvolvido pelo MoMA de Nova Iorque nas décadas de mil novecentos e quarenta e de cinquenta, mais especificamente por René D’Harnoncourt, no tocante às novas abordagens de contextualização do objeto artístico por meio da 'comparação visual' ou pela 
'empatia' entre as obras de arte expostas. René D'Harnoncourt acreditava no poder do "diálogo" visual que se baseava no conhecimento de que o campo de visão do visitante não se limitava apenas aos objetos apresentados em seu trajeto imediato, ou seja, à seção onde ele se encontrava naquele dado momento. Por isso, outros setores da exibição que fossem afins ao que visitava naquele instante deveriam ser visualmente perceptíveis, "descortinados", concomitantemente. René D'Harnoncourt buscava dessa forma traçar um trajeto de visitação que, por meio da justaposição dos objetos expostos, garantisse ao visitante romper barreiras de tempo e de espaço durante uma narrativa de conteúdos, de correlações ou de afinidades, pelo menos em teoria, entre os objetos expostos (DERNIE, 2007: 1112).

O método da 'comparação visual' empregado por René D’Harnoncourt diferenciava-se do empregado nas instalações de seu antecessor Alfred Barr por evitar a sinalização explícita e o material didático. Sua falha, segundo Dernie, consistia na tentativa de reduzir o significado de obras de arte antigas e modernas a estilos ou semelhanças visuais. Entretanto, as ideias defendidas por René D’Harnoncourt influenciaram o trabalho de influentes designers de exibições que empregaram seu método da 'comparação visual' em importantes exibições montadas no século XX. Cita-se como exemplo o historiador e arqueólogo suíço Harald Szeemann e seu trabalho como curador da mostra "Documenta 5" em Kassel, Alemanha no ano 1972 (DERNIE, 2007: 11-12). O evento é por muitos considerado como uma das mais importantes exibições de arte do século $\mathrm{XX}$, sendo tido como um dos precursores das exibições contemporâneas de arte conhecidas como blockbuster que atraem grande número de visitantes, algo sem precedentes há algumas décadas atrás. Ainda, segundo muitos, Szeemann transformou a própria exibição em uma forma de arte. ${ }^{17}$

A década de 1960 deu início a revolucionária exibição interativa que promove meios de engajar ativamente a audiência durante a visitação, ao invés de mantê-la unicamente como observadora. Embora essa revolução tenha se tornado hoje em dia a maneira mais habitual de se montar uma exibição em museus de ciência e de tecnologia, ela não conseguiu se infiltrar fortemente em museus de arte que ainda conservam, na sua grande maioria, um caráter elitista na

\footnotetext{
${ }^{17}$ http://www.cac.It/en/exhibitions/past/11/4625. Acesso em 09/01/2017
} 
apresentação das obras de arte, distanciando-as do público e criando uma atmosfera de deferência (HUGHES, 2015: 17).

Segundo Klein, os museus de arte em especial projetam deliberadamente suas galerias de maneira a não despertar a atenção do visitante para nada além da arte em exposição (KLEIN,1986: 69).

O Centro Georges Pompidou (Centre national d'art et de culture GeorgesPompidou) em Paris é citado por Hughes como exceção dentre os museus de arte da década de 1960. Com o intuito de romper a tradição museal de reverenciar a obra de arte e a maneira de apresentá-la, os arquitetos Renzo Piano e Richard Rogers projetaram um prédio de estrutura massiva e exposta e com tubulação aparente em cores brilhantes. Essa construção hi-tech em nada pode ser comparada a palácios ou galerias de arte tradicionais. Tornou-se uma referência no tocante a exibição de arte moderna, com seus vastos andares desprovidos de colunas internas ou de paredes estruturais que tornam possível a montagem de exibições de arte impactantes, por vezes provocativas e experimentais que, além de outros méritos, atraem uma audiência jovem nem sempre afeita a museus (HUGHES, 2015: 16-18).

Dernie considera que a experiência dos primeiros anos do Centro Pompidou talvez tenha representado a ruptura mais significativa com a tradicional forma de se exibir arte em museus e centros culturais. Ele faz alusão ao ambiente de abertura, flexibilidade e de facilidade de movimento implementado nos espaços expositivos da instituição francesa, o que acredita ter favorecido a interdisciplinaridade, a contextualização das obras de arte tanto em termos de sua interpretação temática como de sua dimensão internacional. Dernie afirma que o sucesso do programa do Centro Pompidou garantiu o surgimento de novas abordagens e perspectivas interpretativas, servindo de exemplo para outros museus tais como Tate Modern em Londres; Dia: Beacon em Nova Iorque (DERNIE, 2007: 12).

Refletindo sobre a atualidade, Dernie considera que a imagem tradicional de museus como locais de depósitos de artefatos em galerias sufocantes já não vigora há muito tempo. Entretanto, lembra que as constantes barreiras ainda impostas entre o visitante e o objeto exposto e a superlotação dos espaços torna a visitação cansativa e maximizam a distração das pessoas. Assim, ele ensina que a ênfase que o moderno Design de Exibições conferia à narrativa da exibição foi 
transferida para a audiência como resposta ao fato dos museus e galerias de arte precisarem competir intensamente por público com setores da indústria do entretenimento. Essa preocupação sobre como as pessoas interagem com o produto, artefato ou marca tornou-se central para o Design de Exibições da atualidade (DERNIE, 2007: 13).

Logo, para melhor competir por audiência, o Design de Exibições deve considerar também o entorno da exposição, ou seja, colocar em relevo as múltiplas atividades que tornam menos cansativas as longas visitações a museus de arte. Festivais, eventos, leituras, performances, cafés e restaurantes fazem parte desse rol de atividades. Essa combinação de atividades oferecidas ajuda a criar um ambiente mais descontraído que alivia o esforço mental do aprendizado ou as longas horas em que o público fica de pé durante a visitação. Como afirma Hughes, os museus com atrações interpretativas oferecidas aos visitantes são locais de convergência de um público cada vez mais internacional que aprecia participar de atividades variadas, complementadas pela contemplação e pelo estímulo que as exibições proporcionam (HUGHES, 2015: 10).

Acredita-se que o Design de Exibições aplicado a museus contemporâneos de arte precisa se ocupar dessas atividades acima descritas, que se mostram tão necessárias como complemento à visitação propriamente dita. Quanto à tarefa de criar espaços expositivos que sejam informados por uma narrativa, embora tenham sido grandes as inovações surgidas ao campo das exibições a partir do século XX, no caso das exibições de arte em museus, elas nem sempre se aplicam com facilidade. Assim explicita Rossini referindo-se à cenografia, entendida pelo próprio autor como sendo uma atividade cujo conteúdo não se distingue daquele do Design de Exibições:

No entanto, há um consenso para exposições de arte e objetos raros. Na maior parte dos casos, o responsável pelo projeto, que pode ser o cenógrafo, o arquiteto, o artista ou o designer, deve preservar alguma sobriedade na escolha dos materiais, cores e organização espacial, os quais possam acolher e mostrar, da melhor forma possível, as peças escolhidas. O ideal contemporâneo defendido e desejado, especialmente pelos artistas e curadores, segue sendo o espaço com pouca interferência: paredes perfeitamente niveladas e com pé direito alto; um conjunto de elementos articulados para proporcionarem uma leitura do público focalizada nas obras expostas.

Se, para as exposições de obras de arte, a cenografia, quando cria um espaço ficcional, pode ser um concorrente que as deprecia e as coloca num segundo plano, como no caso citado, em outros, é a cenografia que apresenta e dá o acesso ao conteúdo de uma exposição. 
O problema não está em defender um termo em detrimento de outro, tampouco considerar que cenografia, arquitetura ou design implicam desvios ou excessos supérfluos no projeto museográfico. $\mathrm{O}$ que interessa é compreender que uma disciplina, no transcurso do tempo, modifica seu escopo conceitual e amplia suas possibilidades de aplicação. Esse é um pressuposto fundamental para pensar a cenografia no campo ampliado e sua aplicação contemporânea em áreas como a Museologia (ROSSINI, 2012: 164).

Nesse capítulo se abordou a evolução das técnicas de exibição de arte em museus e centros culturais, buscando-se traçar as diversas etapas de desenvolvimento da prática no decorrer dos séculos, na Europa Ocidental. Questiona-se, entretanto, no capítulo seguinte, se o emprego do Design de Exibições em mostras de arte é capaz de auxiliar os visitantes a compreenderem melhor o que se exibe, considerando-se que por vezes a Arte pode ser hermética, seja por que já não mais se conhece os signos que a nutriam em eras passadas, seja porque não se fazem conhecer os signos que a informam nos tempos atuais. Nesse mesmo sentido, Anne Cauquelin (CAUQUELIN, 2005: 120) ao exemplificar o percurso artístico percorrido por Andy Warhol, oferece uma definição de arte contemporânea que reflete o seu caráter normalmente codificado.

O percurso sonhado por Andy Warhol - passar do status de artista comercial ao de artista de negócios - está completo. No caminho, fechou-se também a definição de arte contemporânea fora da subjetividade, fora da expressividade - na qualidade de sistema de signos circulando dentro de redes. Definição estrita, quase insuportável em seu rigor. (Grifo nosso) 


\section{Aplicação do Design de Exibições em exposições de arte, participação do público, desencriptação.}

A ideia de desencriptação de constituições defendida pelos autores Gabriel M. Hicapie e Ricardo Sanin Restrepo no campo do Direito Constitucional poderia servir de fonte de inspiração para se pensar uma nova postura a ser adotada pelo Campo das Artes Plásticas, no intuito de facilitar o acesso, a fruição e a compreensão da arte às esferas menos elitizadas da população. Pergunta-se se o Design de Exibições que tem por meta dispor objetos de arte no espaço expositivo, considerando o visitante como sujeito principal de suas preocupações, seria uma ferramenta útil no processo de desencriptação da arte aos não iniciados.

Os acima mencionados autores falam da encriptação da constituição como meio de torná-la incompreensível aos não iniciados na linguagem tecno-legal do texto. Acreditam que tal encriptação torna o texto indecifrável a todo aquele que não compartilha do conhecimento preciso da linguagem utilizada. Assim, somente um pequeno grupo teria a chave do conhecimento para a perfeita compreensão das palavras escritas, adquirindo dessa maneira uma enorme vantagem em relação ao que chamam de leitores não autorizados. Essa vantagem seria o surgimento de uma falsa certeza de que apenas uns poucos experts teriam o conhecimento e as condições de resolver problemas complexos nas áreas da política e do Direito. Segundo os autores, trata-se de um mecanismo para se legitimar a privatização da política e do Direito e para se reduzir o alcance dos direitos e garantias previstos em constituições. Concluem fazendo referência à exclusão política e social que advém da privatização da cultura: La encriptacion crea zonas rígidas de exclusion politica y social a partir de la privatizacion de la cultura. (HINCAPIE \& RESTREPO, 2012). ${ }^{18}$

Pensando em como se desencriptar exposições de arte, que normalmente dependem do prévio conhecimento da linguagem da arte para sua compreensão,

\footnotetext{
${ }^{18}$ A encriptação cria zonas rígidas de exclusão política e social a partir da privatização da cultura. (tradução nossa)
} 
alguns teóricos que pensam tais exibições ${ }^{19}$, buscam descobrir os anseios e as necessidades do público visitante, o que se conhece por estudos de avaliação.

A presente pesquisa não pretende se aprofundar no extenso e importante tema da avaliação realizada em museus. O assunto é sucintamente lembrado apenas como uma valiosa fonte de informação a pautar a atuação do designer de exibições de arte em museus.

Por meio de pesquisa realizada pelo Centre d'Etudes et de Recherche sur les Expositions et les Musées (CEREM) ${ }^{20}$ e publicada por Jean Davallon e outros, sabe-se que os comentários dos visitantes surpreendem até mesmo a curadores e consultores, por levantarem perguntas que vão além da exposição visitada mas que se referem a uma crítica mais ampla dos esquemas expositivos em geral (DAVALLON \& GOTTESDIENER \& POLI, 2000: 60). As opiniões emitidas foram analisadas em conjunto, dados foram obtidos e passaram a ser considerados índices da capacidade do visitante de ser parte ativa no projeto do design de exibições, demonstrando a extensão na qual a experiência da audiência deve ser considerada. A pesquisa demonstrou que o visitante se afirma não apenas como um receptor-leitor, mas também como um agente ativo, um coparticipe do projeto.

O texto L'espectateur emancipé escrito por Jacques Rancière (RANCIÈRE, 2008: passim) trata da mesma questão quando se refere ao espectador do teatro. Compreende-se que seu escrito se aplica brilhantemente também para a situação do observador/ator de exibições de arte (SCHWARTZ \& CIPINIUK. 2016). Rancière rechaça a noção da participação meramente passiva do receptor de uma peça de teatro para ver o espectador como um sujeito que participa ativamente do processo que se desenrola à sua frente, correlacionando o que vê às suas próprias experiências e considerações, conferindo significados únicos e individuais àquilo que se expõe.

Lisbeth Rebollo Gonçalves não compreende como participação ativa a do espectador das artes cênicas, entretanto, considera que há uma aproximação muito direta entre a comunicação que ocorre em uma exposição e a que acontece durante uma peça de teatro. Conclui, a seguir, que o visitante de exposições pode ser visto como ator, como partícipe ativo do evento.

\footnotetext{
${ }^{19}$ Cita-se CURY, 2006 como exemplo de bibliografia nacional a ser consultada.

${ }^{20}$ Centro de Estudos e de Pesquisas sobre as Exposições e Museus.
} 
A separação entre a cena e o espaço do espectador desaparece na exposição e o visitante pode ser entendido como um ator, no sentido de que, percorrendo o circuito da mostra, é um ser ativo (um corpo presente e fundamental) no seu dispositivo. O seu percurso, a deambulação, é fundamental (GONCALVES, 2004: 21).

Sandra Sunier ao perceber que, em regra geral, as pesquisas sobre museus pouco se dedicam ao estudo do trabalho que precede a realização de exposições, escreveu o texto Le scénario d'une exposition que aborda principalmente a produção do discurso conceitual criador da exibição, mais comumente denominado de cenário da exposição, segundo informa a autora. Ela constata que tal discurso prévio ou não transparece na exposição ou é transmitido de maneira extremamente codificada. Como consequência, Sunier conclui que

o visitante, dentro de um espaço desconhecido, tenta construir um sentido para a sua visitação e tenta tomar conhecimento do espaço que ocupa e que busca controlar baseando-se em jogo de luzes, de cores, paralelismos de forma, posicionamento dos objetos no espaço, por exemplo. Esse trabalho de construção de sentido em relação ao espaço o conduz a realizar suas pesquisas segundo a lógica daqueles que conceberam os conceitos das exposições que visitam (SUNIER, 1997: 195). ${ }^{21}$

Em questionário submetido a duas profissionais da área de exibições em museus, colocava-se a seguinte pergunta: Em uma exibição de arte há uma ou mais mensagens a transmitir aos visitantes? A mensagem é dada por quem? Ou deve-se entender que essa ideia de mensagem é ultrapassada quando da elaboração de uma exibição de arte, a fim de se permitir ao visitante entender o que vê como bem deseja, utilizando suas próprias referencias para compreender a exibição?

Liana Brazil, arquiteta, respondeu da seguinte maneira:

Essa análise precisa ser feita sobre um exemplo. Se há uma ou mais mensagens, depende do tema, do conteúdo ou das obras. Não

\footnotetext{
${ }^{21}$. Le discours, qui généralement précède la constitution d'une exposition, n'apparaît en effet pratiquement pas dans l'espace muséal ou alors de manière extrêmement codée. Le visiteur se retrouve pris dans un espace inconnu et c'est en essayant de construire du sens à partir de divers repères (jeux de lumière, couleurs, parallélismes de formes, emplacements dans l'espace, etc.) qu'il va tenter de prendre connaissance de cet espace et ainsi de le maîtriser. Ce travail de construction de sens le conduit à rechercher selon quelle logique les concepteurs d'expositions ont dressé le champ d'étude qui se présente à ses yeux. (SUNIER, 1997: 195)
} 
entendo como mensagem algo que se impõe ao visitante, pelo contrário. É possível comunicar um conceito ou mensagem principal da exposição deixar que cada visitante absorva esse conteúdo do seu jeito, com seu conhecimento e sua formação. Por exemplo, na exposição Perimetral (eu, Russ, Vik e Andrucha) tínhamos uma missão clara de passar para o visitante os diversos aspectos da transformação urbana que a queda da Perimetral representa. Como artistas, exploramos todos os aspectos que nos interessavam e os representamos com imagens e sons. Essa escolha é do artista ou do designer, e é o que define a exposição. Tenho certeza de que cada pessoa que entrou viu algo diferente, prestou atenção a detalhes diferentes, saiu com uma impressão diferente. A mensagem ou as mensagens estavam lá iguais para todos. Cada um vê da forma que quer. (Grifo nosso)

Já na década de 1960, Bourdieu e Darbel (BOURDIEU \& DARBEL, 1966: passim) publicaram pesquisa que concluiu que grande parte do público francês que visitava exposições de arte saía do museu sem fruir ou entender o que vira.

Também Anne Cauquelin concluiu na mesma esteira de raciocínio de Bourdieu e Darbel ao referir-se à arte contemporânea, posicionamento este compartilhado pela presente pesquisa. Segundo opina,

Agrupamos aqui as constatações preliminares: a arte contemporânea é mal apreendida pelo público, que se perde em meio aos diferentes tipos de atividade artística mas é, contudo, incitado a considerá-la um elemento indispensável à sua integração na sociedade atual. Aonde quer que se vá, não importa o que se faça para escapar, a arte está presente em toda parte, em todos os lugares e em todos os ramos de atividade. [...] No nível artístico, as consequências são tão perturbadoras quanto a confusão que se opera no espírito do público (CAUQUELIN, 2005: 161). (Grifo nosso)

Pergunta-se se a aplicação do Design de Exibições em exibições de arte pode auxiliar a tornar a visitação dessas mostras mais proveitosa tanto do ponto de vista do prazer estético quanto da apreensão de conhecimento e, portanto, menos frustrante ao visitante. Teria ele o poder de participar do processo de desencriptação do hermetismo tantas vezes presente nas artes plásticas?

A hipótese levantada como objetivo de nossa pesquisa, a de que o Design de Exibições poderia sozinho tornar as exibições de arte mais compreensíveis aos visitantes, não se confirmou. O material bibliográfico até agora consultado afirma que esse ramo do design que se ocupa da disposição de objetos no espaço de exposição, tem sua atuação intimamente condicionada à vontade do curador da mostra, ao perfil da instituição e aos seus financiadores. Assim, embora a mencionada atividade profissional tenha no público o foco principal de sua atuação, embora disponha de ferramentas para tornar a exposição de arte mais 
agradável de ser visitada pela manipulação da luz que incide nos objetos de arte, pela criação de mobiliário de exposição que não obstrua a visualização dos mesmos, pela propagação da informação por meio de mídias diversas, pela estipulação ou não de trajetos de visitação, apenas à guisa de exemplos, nada disso terá o poder suficiente de se sobrepor à intenção por acaso existente da instituição museal, de seus principais mantenedores e em consequência do curador da mostra de manter o conhecimento acessível somente a poucos iniciados em arte.

Acredita-se ainda que essa capacidade de desencriptar o conhecimento relativo às artes plásticas, se essa for a vontade da instituição museal e de seus dirigentes, merece ser uma tarefa a ser perseguida de maneira multidisciplinar. O setor educativo do museu tem um importante papel a exercer nesse sentido. $\mathrm{O}$ recurso a soluções de design e de cenografia podem contribuir para tornar a exibição mais amigável, mas não serão suficientes, por si só, para se conseguir vencer barreira do hermetismo que costuma ser intrínseco às obras de arte, especialmente se consideradas as contemporâneas.

Mas, principalmente, e acima de tudo, o ensino relacionado às artes plásticas merece, pela sua importância histórica e pelo seu potencial de promover consciência social, fazer parte de uma política governamental de valorização de sua compreensão e de sua prática, com o consequente estímulo de sua propagação às mais variadas camadas da população brasileira.

Desencriptar a compreensão e a fruição de obras de arte por um público cada vez maior e mais consciente depende de ações planejadas e estruturadas em um âmbito maior, governamental, algo que escapa ao alcance e ao domínio do Design de Exibições, pelo menos no Brasil, ainda que a atividade se oriente em conformidade com estudos e pesquisas de avaliação de público. 


\section{Design de Exibições e sua importância no cenário internacional.}

Diversos autores que trabalham sobre os temas relativos aos museus de arte, exibições e seus públicos confirmam a crescente relevância que vem sendo conferida a estes assuntos nas últimas décadas.

Nesse sentido, cita-se Jean-François Barbier-Bouvet (BOUVET, in. VERON \& LAVASSEUR, 1989: 07) que afirma que a multiplicação de pequenas exposições sobre todos os assuntos na França nas últimas décadas e que o sucesso espetacular das maiores, que atingem por vezes números até então reservados ao cinema, atraem de tal forma o visitante de exposições. Segundo Bouvet, o museu acabou por se tornar uma figura familiar da paisagem cultural, entretanto, apesar do autor constatar a crescente visitação a museus, ele percebe também que a realidade do visitante ainda não se mostra amplamente compreendida ${ }^{22}$.

Muitas pesquisas vêm sido desenvolvidas no cenário internacional, majoritariamente a partir da década de 1970, sobre o assunto denominado "estudos de visitantes" (visitors studies) ou "pesquisa de visitante de museu" (museum visitor research), categoria que integra a chamada avaliação museal. Conforme explica Cury (CURY, 2006: 62), esse estudo busca entender o uso que os visitantes fazem de exposições, ou outras atividades ou programas públicos de museus e suas atitudes, percepções, aprendizado, motivações, comportamento e interações sociais.

Embora essas pesquisas ainda sejam pouco praticadas pelas instituições museológicas do Brasil (CURY, 2006: 62), isto é, a pesquisa para se entender o que o visitante procura ou deseja encontrar em uma exibição nos parece ser

\footnotetext{
22 Le visiteur d'exposition est devenu une figure familière du paysage culturel. La multiplication des petites expositions - en tous lieux et sur tous sujets - depuis une vingtaine d'années, le succès spectaculaire des plus grandes, qui atteignent parfois des chiffres jusqu'ici réservés au cinéma ou à l'édition, nous le font rencontrer partout; quand nous ne sommes pas nous-mêmes l'un d'entre eux. Mais ce n'est pas parce qu'lls nous sont familiers qu'ils nous sont véritablement connus. (BOUVET, in. VERON \& LAVASSEUR, 1989: 07)
} 
primordial no que tange ao Design de Exibições de arte, posto que essa modalidade de design persegue a meta de produzir exposições que atraiam o público, e que sejam consideradas "amigáveis" e informativas ao mesmo tempo para o utente.

É importante lembrar que os designers argumentam sistematicamente que deve haver uma simetria entre a forma e a função dos projetos que realizam, daí uma exposição que tenha sido planejada por um designer precisa ser "amigável" e funcional ao mesmo tempo, enfim, o design deveria seguir o velho princípio de que a "forma segue a função", no sentido de que o visitante de uma exibição de arte deveria ser beneficiado por uma série de princípios funcionalistas que deveriam facilitar a sua compreensão disso que é ou vem a ser a Arte. Para tanto, há que se conhecer profundamente o sujeito social para quem essas exposições são elaboradas.

Como escreve Bouvet (BOUVET, in. VERON \& LAVASSEUR, 1989: 07), embora dados como idade, nível social, frequência de visitação a exibições por parte desses visitantes já sejam atualmente disponíveis, a investigação científica continua tentando desvendar temas outros, aqueles relativos à visitação a exibições. Alguns exemplos são por ele citados: como o visitante olha realmente uma obra de arte, um objeto, um painel; como despertar a sua curiosidade ou o que a desestimula; como se constrói a compreensão do objeto de arte ou como ela escapa, como se manifesta o prazer ou o tédio no visitante. Com perspicácia, o autor escreve que se é verdade que para quem concebe a exibição, ela é um lugar onde não se pode tudo mostrar, ela é também, frequentemente, para os visitantes um lugar onde não se pode tudo ver. ${ }^{23}$ René Vinçon compartilha da mesma ideia de que não se consegue tudo mostrar e, portanto, tudo se ver em uma exposição (VINÇON, 1999: 15.).

Jean-François Lyotard (LYOTARD, 1988: 140) ao escrever sobre a arte dos pintores das vanguardas modernistas e pós-modernistas do século XX, ensinou que tais artistas, como membros de uma "classe intelectual", deveriam se defrontar com a responsabilidade de refletir sobre uma pergunta, qual seja, a de

\footnotetext{
${ }^{23}$ S'il est vrai que pour ses concepteurs l'exposition est un endroit où on ne peut pas tout montrer, elle est aussi le plus souvent pour les visiteurs un endroit où on ne peut pas tout voir. BOUVET, in. VERON \& LAVASSEUR, 1989: 07
} 
como fazer compreender nossa pintura aos que não são artistas? Acredita-se que essa pergunta mantém fortemente sua relevância no século XXI, época de produção de artes diversificadas, tantas vezes herméticas, que foram se apartando da compreensão do público. Entende-se que cabe ao artista contemporâneo se responsabilizar por tentar responder à pergunta que acima se colocou, mas como quase sempre os artistas se dedicam apenas à produção dos seus trabalhos, caberia à crítica, ou aos teóricos, ou aos que projetam ou planejam espaços de exibição, essa explicação.

Na presente pesquisa entende-se que a importância do Design de Exibições aplicado em museus de arte reside justamente na sua busca por mostrar, evidenciar ao máximo, para o público visitante, aquilo que se concebeu exibir. $\mathrm{O}$ Design de Exibições pode ser um aliado do artista na sua responsabilidade de auxiliar e de permitir aos não artistas compreenderem seus trabalhos artísticos e compartilharem de suas visões de mundo. O Design de Exibições pode representar uma ferramenta útil à tentativa de democratização da arte, apresentando-a de maneira prazerosa e estimuladora da curiosidade do público, facilitando a transmissão de conteúdo. Ao mesmo tempo, as soluções que podem ser ofertadas pelo Design de Exibições devem ser hábeis em esconder aquilo que poderia ofuscar esses objetivos acima elencados.

Como novamente ensina Bouvet, não é o bastante organizar-se um encontro improvisado entre um público e uma exposição para que se estabeleça automaticamente uma relação (BOUVET, in. VERON \& LAVASSEUR, 1989:11 ${ }^{24}$. Há que existir uma familiaridade entre ambos. Tendo ciência dessa necessidade de se criar uma familiaridade entre o visitante e a exibição que auxilie a visitação, o Design de Exibições busca facilitar essa familiaridade ao se ocupar dos suportes que estão presentes em quase todas as exposições, aqui incluídas as exposições de arte. São eles o texto, a imagem, os objetos, e por vezes vídeos, som ou olfato. Enfim, parece que Bouvet considera que o problema da exibição de uma exposição de arte pode ser resolvido no âmbito de uma boa concepção técnica ou funcional da exibição, seja lá isso que ele compreende por boa concepção. Na presente pesquisa concorda-se parcialmente com tal abordagem. Se

24 II ne suffit pas d'organiser la rencontre impromptue entre un public et une exposition pour que s'établisse automatiquement une relation. Ou pour dire les choses autrement il ne suffit pas au visiteur potentiel de passer devant pour rentrer dedans. 
de fato as questões técnico-funcionais precisam ser consideradas para o sucesso de um projeto expográfico, acredita-se que apenas a técnica, por mais eficaz que ela seja, por mais respostas que possa trazer, não resolve ou não explica necessariamente todos os problemas e indagações que possam surgir desde a fase inicial da concepção até a inauguração de exposições de arte ao público.

Victoria D. Alexander (ALEXANDER, 1996:03) observou que a maioria da população dos Estados Unidos da América vê arte e aprende sobre artistas em museus de arte. Segundo a autora, poucas pessoas cultivam o habito de visitar os ateliês dos artistas e quando o fazem, escolhem aqueles cujos trabalhos são representados e vendidos por galerias de arte. A autora confirmou ainda que os museus de arte legitimam o trabalho de novos artistas e reforçam a legitimação já conferida a obras de artistas famosos, vivos ou não. Acredita-se que a realidade brasileira se mostra similar à estado-unidense. $\mathrm{O}$ brasileiro, ou pelo menos o carioca, que busca conhecimento sobre arte visita principalmente exibições de arte em museus e em centros culturais. Países que já perceberam a importância do museu e de suas exibições para instruir a população sobre arte creditam ao Design de Exibições o potencial de melhorar as mostras que promovem.

Katharina Hegewisch (HEGEWISCH, 1998: 15) ensina que desde que as exposições existem, elas são alvo de críticas. Entretanto, afirma que essa antiga mídia de comunicação artística ao mesmo tempo em que conhece grande sucesso, paradoxalmente cria desconfianças em seu público, em seus críticos e artistas. Critica-se que a exposição seria uma maneira incompleta de apresentação das obras posto que não faria justiça a essência da arte. Daí voltamos a nos perguntar qual seria essa essência e como uma exibição de arte conseguiria respeitá-la? Mais ainda, como um designer poderia auxiliar nessa tarefa?

Douglas Crimp (CRIMP, 1984: 50-1) em 1984 já exprimia sua surpresa ao descrever o discurso proferido em 1982 por Rudi Fuchs durante conferência promocional da custosa exibição Documenta7, em Nova Iorque. Fuchs, o diretor artístico da mostra, havia dedicado mais da metade de sua fala não para as obras que seriam expostas, mas sim, para relatar o progresso dos trabalhos realizados para a finalização dos espaços expositivos. Segundo Fuchs, a arte, pela sua nobreza, não deveria mais ser exibida em espaços que não lhe conferissem a dignidade e o respeito merecidos. A exibição de arte exigiria paredes permanentes, estruturas temporárias não seriam mais suficientemente adequadas 
ao nobre propósito. Crimp transcreve ainda trecho do prefácio escrito por Fuchs para o catálogo da referida mostra, em que o último sintetiza sua ideia sobre a arte de exibir. Para ele, uma exibição será construída apenas depois que o espaço expositivo tenha sido preparado. No meio tempo, os artistas se aplicam em criar obras de arte apropriadas para a ocupação desse espaço especial. Leia-se as palavras proferidas por Fuchs, transcritas por Crimp (FUCHS, in.: CRIMP, 1984: 50-1):

"I feel", he said, "that the time one can show contemporary art in makeshift spaces, converted factories and so on, is over. Art is a noble achievement and it should be handled with dignity and respect. Therefore, we have finally built real walls".

"We practice this wonderful craft, [...] we construct an exhibition after having made rooms for this exhibition. In the meantime artists attempt to do their best, as it should be".

Acredita-se que a prática do Design de Exibições vem afirmando sua importância internacionalmente desde a segunda metade do século XX, impondose ativamente em mostras de museus de arte. Lista-se de maneira não exaustiva alguns países onde se observa esse fenômeno: Estados Unidos da América, Canadá, França, Singapura, Inglaterra, Alemanha, Itália. Concorda-se com o motivo descrito por Larry Klein (KLEIN, 1986:64) para justificar esse fato como sendo a necessidade sentida pela instituição museu de renovar, revigorar, modernizar sua imagem. Uma imagem que seja menos empoeirada ou tediosa e sim, que transmita uma ideia de acessibilidade a todos com o intuito de atrair vasto público para suas atividades e também, a fim de integrar mais ativamente os membros dos museus ao quotidiano da instituição. Para tanto, como informa Klein, os museus vêm recorrendo em larga escala aos serviços prestados por profissionais de relações públicas, de propaganda e designers..$^{25}$

Essa atitude adotada pelos museus colaborou para acelerar o profissionalismo dos designers de exibições no século $\mathrm{XX}$ algo que, segundo o autor, se iniciou timidamente nas décadas de 1950 e 1960 quando alguns dos grandes museus criaram departamentos internos de design, elencados ao mesmo

${ }^{25}$ Museums are trying to polish up a dull and dusty public image by taking stands on public issues, staging activities which invite participation such as ethnic festivals, and involving their members more fully in museum life. They are using professional public relations, advertising, and design consultants on an ever-increasing scale. 
patamar hierárquico dos departamentos de curadoria. Isso determinou uma grande mudança nas estruturas de poder dessas instituições pois conferiu responsabilidade e autoridade aos departamentos de design tanto no que se refere ao design das exibições como para participar da função de planejamento em geral das mesmas. Até então, repetindo-se Klein, cabia aos curadores o total controle das galerias de exibição (KLEIN, 1986: 64). ${ }^{26}$

Segundo Larry Klein (KLEIN, 1986: 65), um típico departamento de exibição de um grande museu norte-americano, tal como o Metropolitan Museum of Art de Nova Iorque, devia contar com um quadro de uns trinta ou mais profissionais. Seriam eles os designers de exibição e os designers gráficos, os artistas de produção, os escritores de scripts, os coordenadores e os técnicos e artesãos responsáveis pela montagem e manutenção das exposições. ${ }^{27}$

Tendo-se buscado demonstrar a importância conferida ao Design de Exibições no cenário internacional, o capítulo seguinte terá por intuito analisar a sua prática no Brasil e o seu ensino no Rio de Janeiro.

${ }^{26}$ All of this is helping to accelerate the professionalism of museum designers that began slowly in the fifties and sixties when a few of the larger museums set up centralized design departments. These were placed on an equal basis with the curatorial departments which was a major change in the internal power structure of the institutions. Until then curators had complete control of the exhibition galleries.

${ }^{27}$ A typical exhibit department of a major museum (such as the Metropolitan Museum of Art or the American Museum of Natural History in New York, or the Field Museum of Natural History in Chicago, and the Smithsonian's museums) may have a staff numbering thirty or more. The department will include exhibit and graphic designers, production artists, script writers, coordinators, and preparators (the technicians and craftspeople who build and maintain the exhibits). 


\section{Design de Exibições, sua prática no Brasil e o seu ensino no Rio de Janeiro.}

No Brasil o Design de Exibições ainda caminha para afirmar a sua importância. Acredita-se que no campo das montagens de exposições de arte em museus e bienais realizadas nas capitais brasileiras ele já se tornou uma prática constantemente empregada. No questionário respondido por escrito por duas profissionais do campo e oralmente pelos demais entrevistados, uma das perguntas que se colocou foi: o Design de Exibições já é bem conhecido, divulgado e aplicado em exposições de arte no Brasil?

Liana Brazil, arquiteta na empresa SuperUber, trabalha com projeto e montagem de exibições de arte em museus e eventos desde o ano de 2002. Ela respondeu por escrito à pergunta com precisão, ilustrando com clareza o panorama não apenas da prática, mas também do ensino do Design de Exibições no Brasil. A seguir transcreve-se sua resposta: Sim, mas não formalmente. Os designers mais expressivos que conheço sei que não tiveram um treinamento formal sobre isso, e sim desenvolveram seus estilos e sua prática trabalhando.

No mesmo sentido foi a resposta escrita fornecida por Marta Vieira Bogéa, arquiteta, mestre em Comunicação e Semiótica e doutora em Arquitetura e Urbanismo, professora no Departamento de Projeto da Faculdade de Arquitetura e Urbanismo da USP e que atua na área de Design de Exibições em exposições de arte desde 1995, acredita que o Design de Exibições já é bem conhecido, divulgado e aplicado, mas pouco analisado e registrado. Foi-lhe perguntado também se entendia ter o Brasil desenvolvido uma expressão própria, um modo característico de aplicar o Design de Exibições em exposições de arte em seus museus? Ou se a influência estrangeira ainda se mostra determinante? Segundo Marta: Entendo como em qualquer linguagem atual, que apresentam expressão com certa "dicção" local, mas com aprendizagem e trânsito universais.

Ana Luísa Nobre, arquiteta, pesquisadora com ampla produção acadêmica, professora do Departamento de Arquitetura da Pontifícia Universidade do Rio de 
Janeiro (PUC Rio) e coordenadora do Departamento Educativo do Instituto Moreira Salles, concedeu entrevista em setembro de 2016. Afirmou acreditar que o exemplo mais conhecido de Design de Exibições desenvolvido no Brasil seria o de Lina Bo Bardi, para o Museu de Arte de São Paulo (MASP). Citou a exposição temporária, inaugurada em 19 de agosto de 2014 no Museu da Casa Brasileira em São Paulo, que homenageou as maneiras de expor da celebrada arquiteta. ${ }^{28}$ Embora de nacionalidade italiana, Lina Bo Bardi morou por longos anos no Brasil e seu projeto autoral nasceu muito de sua íntima convivência com a cultura brasileira e de sua releitura. Entretanto nossa entrevistada disse discordar da existência de um modo caracteristicamente brasileiro de se aplicar o Design de Exibições em nossos museus. Inclusive acrescentou ser uma bobagem pensar-se nisso considerando-se que hoje há muita gente trabalhando com exposições e que essas pessoas, as próprias exposições, os artistas, as obras de arte circulam muito e por isso Ana Luísa Nobre não acredita em uma identidade nacional, mas sim em adaptação da exposição ao espaço pré-existente.

Luísa Mello concedeu entrevista em junho de 2016. Formada em História pela Universidade de São Paulo e em História da Arte pela Université Paris I Sorbonne, possui pós-graduação em História da Arte e Arquitetura do Brasil pela PUC-RJ e exerce a função de diretora geral da Automática, empresa que atua nas áreas de produção cultural e editoração. ${ }^{29} \mathrm{~A}$ entrevistada trabalha há dezesseis anos no processo de elaboração de exposições, sendo que por onze anos atua como produtora cultural. Afirmou que do total de seus projetos, cerca de oitenta por cento diz respeito à concepção e montagem de exposições, sendo que desse universo, noventa e cinco por cento se refere a exibições de arte.

Segundo Luísa Mello, o Design de Exibições já seria bem conhecido dos profissionais de arte brasileiros, das pessoas do meio e por vezes, também do nosso público. Observou também que um exponencial grande de arquitetos trabalha na sua prática. No tocante à pesquisa sobre o tema, afirmou lhe parecer que o Brasil não a desenvolve tanto como poderia, já que as instituições culturais que promovem exibições de arte por aqui geralmente não contam com uma equipe

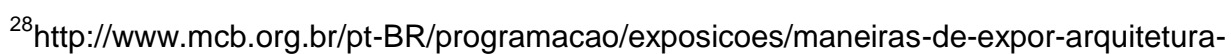
expositiva-de-lina-bo-bardi, disponível em 11/11/2016

${ }^{29}$ http://www.automatica.art.br/equipe.php
} 
interna especializada em projetar e montar exposições. Veem-se, por consequência, obrigadas a recorrer a produtoras culturais terceirizadas para a realização da tarefa, realidade essa diferente da que se percebe em muitos países estrangeiros em cujos grandes museus contam com uma larga equipe especializada em projetar e montar exibições.

Quanto ao ensino do Design de Exibições, Luísa Mello considera que no Brasil não se produziu teoria suficiente sobre o tema. Esse fato poderia ser um fator para justificar o jeito brasileiro de aplicar o Design de Exibições não baseado na teoria, mas sim, aprendendo-o com a prática, com o fazer. Reafirmou, entretanto, a alta qualificação de muitos dos profissionais que atuam na área e que tantas vezes encontram soluções sofisticadas de expografia ainda que desafiados pela repetida escassez de verbas.

Por conta das respostas que obtivemos, foi possível perceber no decorrer da pesquisa que o Design de Exibições já vem sendo aplicado regularmente às exibições de arte projetadas ou montadas no Brasil, mas é preciso ressaltar que as respostas foram vagas, isto é, de natureza subjetiva, mais de acordo com interpretações pessoais dos entrevistados, portanto ainda não podem ser consideradas como uma delimitação clara disso que é a prática do design de exibições. Ademais, os profissionais que se ocupam dessa prática, não mencionaram ou não se preocuparam em definir com clareza o que seria isso que é a prática do design de exibições, seja ele realizado aqui no Brasil ou no exterior. A maior parte dos comentários foram sobre os procedimentos cotidianos, como eles se confrontam com problemas do ambiente museal, com artistas e curadores.

Confirmou-se, entretanto, que os profissionais brasileiros que atuam no ramo aprenderam o ofício na prática, não receberam uma formação acadêmica sobre o assunto. As escolas que ministram o ensino superior de Design do país, ou pelo menos no Rio de Janeiro, ainda não perceberam a relevância da matéria e a importância de ensiná-la formalmente a seus alunos.

Em entrevista com Cintia Kury Souto realizada em setembro de 2016, o tema sobre o ensino superior do Design de Exibições no Brasil foi detalhadamente abordado. A entrevistada é formada em Design pela Escola Superior de Desenho industrial (ESDI) do Rio de Janeiro e foi professora adjunta da Escola de Artes Visuais do Parque Lage (EAV), no Rio de Janeiro, onde lecionou o curso Design de Exposições, ministrado em conjunto com seu marido e também professor Luis 
Alberto Garcia Zúñiga, oferecido entre os anos de 2009 a 2014. Ambos integravam também o corpo docente do Ateliê da Imagem, inaugurado em 1999, dedicado ao ensino e fomento da fotografia e da imagem no Rio de Janeiro. ${ }^{30}$ Cintia Kury trabalhou como designer de exibições desde 1984. Integrou a equipe do departamento de design do Museu da República no Rio de Janeiro ${ }^{31}$ a partir do ano de 1986 até o ano de 2012. Nessa instituição exerceu a função de assessora cultural (ou produtora cultural) de 2008 até 2013, tendo sido, portanto, responsável pelos assuntos referentes à aglutinação e à administração de todos os profissionais envolvidos no processo multidisciplinar de elaboração e montagem de exposições em museus.

Perguntada se o Design de Exibições é bem conhecido no Brasil, Cintia Kury respondeu que considera haver pouca literatura nacional sobre o tema. Prosseguiu afirmando que as nossas escolas de design não trouxeram esse assunto ao seu curriculum, a questão relativa aos espaços não recebeu das faculdades de design importância a ponto de torná-la uma disciplina. Cintia Kury credita o porquê disso ao fato de que, durante muito tempo, esse assunto ocupação dos espaços foi estudado e tratado mais pela arquitetura por conta de ser da praxe do arquiteto projetar habitações. Como consequência, a atuação do arquiteto acabou se estendendo também para os ambientes de museus. Entretanto, Cintia Kury acredita que na atualidade, com o crescimento numérico dos museus e espaços culturais nacionais e das possibilidades de expor, o assunto deixou de ser predominantemente tratado pela arquitetura e se ampliou para outras áreas de atuação profissional.

Cientes da escassa produção de bibliografia nacional sobre Design de Exibições, conscientes da demanda que se verificava por parte do campo cultural carioca por profissionais capacitados para exercerem a função de designers de exposições e, portanto, inspirados pelo intuito de formar tais profissionais brasileiros, Cintia Kury e Luis Alberto Garcia Zúñiga ministraram entre os anos de 2009 a 2014 o curso Design de Exposições na Escola de Artes Visuais (EAV) do Parque Lage do Rio de Janeiro. Tratou-se de uma experiência pioneira no estado.

\footnotetext{
${ }^{30} \mathrm{http}: / / \mathrm{www}$.ateliedaimagem.com.br/escola.php

${ }^{31}$ Ibid.
} 
Pela leitura das disciplinas do curso, percebe-se que ele era multidisciplinar na abordagem dos conhecimentos necessários a quem desejava se profissionalizar como designer de exibições, ensinando matérias não apenas relacionadas ao campo do Design, mas também ligadas à geografia, à logística, à museologia. Além da parte teórica, as turmas realizavam visitas a exposições em museus e centros culturais a fim de observarem a prática da profissão. Segundo divulgado pela EAV do Parque Lage:

Design de Exposições.

Professores: Luis Alberto Zuniga e Cintia Kury Souto.

O objetivo do curso é compartilhar com estudantes e profissionais de design, artes, arquitetura, museologia e afins, a experiência do trabalho de projeto e montagem de exposições, através de apresentações dinâmicas, narrativas, imagens, plantas e maquetes de diversos projetos. ${ }^{32}$

A seguir se inclui o programa do curso, gentilmente fornecido pela entrevistada.

Design de Exposições.

Programa Geral do Curso:

Parte 1: fundamentos

Conceituação e conhecimento

Tipologia e características de exposição e de conteúdo

Geografia, definição e possibilidades de ocupação de espaços

Consciência de dimensões, relações micro e macro

Escala, planta e maquete

Ferramental de trabalho e seu uso

Meios de representação, materiais e processos

Produção e logística

Manuseio e embalagem

Transporte e deslocamento

Parte 2: práticas

A experiência Institucional

O papel dos museus e seus acervos

${ }^{32} \mathrm{https}: / /$ groups.google.com/forum/\#!topic/consciencia-cultural/UbWa7WsJZYU disponível em 10 de novembro de 2016. 
Linguagens do layout de espaços

Conceitos - conviver, interferir, adaptar

Mobiliário de exposição

Estudo e apresentação de casos

Processos de montagem e execução

Visitas comentadas

Desenvolvimento de atividades práticas e exercícios

Experimentação

O mencionado curso durava um semestre, tempo considerado suficiente para o ensino da parte teórica e prática. Palestrantes de diferentes categorias profissionais tais como curadores, iluminadores, cenógrafos eram convidados a expor suas experiências e assim fomentar visões novas e integradas nos alunos. Ao final do curso, os discentes apresentavam uma proposta de exposição que poderia vir a ser de fato montada, dependendo da disponibilidade de um espaço para tanto. Na ausência desse espaço, o projeto era todo montado em maquetes. Por vezes, o casal de professores já estava montando alguma exposição e então os alunos participavam ativamente do processo.

Cintia Kury aproveitou para ressaltar a importância do fato que, durante os anos em que trabalhou no Museu da República, a memória dessas exposições foi toda documentada e armazenada, seja por meio de fotografias do processo de montagem, seja por suas plantas, pelas memórias descritivas das reuniões ou pelas discussões que foram gravadas. Esse rico material deve constar do arquivo que hoje se chama arquivo institucional do museu. A instituição arquiva ainda toda a folheteria que produziu para suas exposições como folders, convites. Esse importante trabalho tem sido realizado por Isabel Portella, doutora em História e Crítica da Arte e museóloga que faz parte do quadro de pessoal do museu.

Cintia Kury explica que realizava visitas práticas a exibições de arte não apenas com os alunos das turmas da Escola de Artes Visuais do Parque Lage, mas também com a equipe do Museu da República onde trabalhava. Afirma que além de instrutivo, essas visitas eram divertidas porque o grupo ia não para visitar a exposição, mas para vê-la com os olhos de quem as monta, observando aspectos tais como, por exemplo, a altura das vitrines expositivas; o conforto da visualização por parte do visitante. O grupo geralmente observava o uso do 
recurso do espelho que, quando interativo, ficava com a marca das mãos das pessoas. Observava ainda quais tipos de materiais, texturas, coberturas, pinturas que poderiam ser empregados em projetos expográficos. Cintia Kury ensina que todas essas questões foram evoluindo muito e que o designer precisa se manter atualizado sobre isso tudo. Novas possibilidades foram surgindo com o decorrer do tempo também na forma de apresentar textos, seus tamanhos, as legendas.

Enfim, pode-se perceber que o curso, por longos anos ministrado pelo casal, foi pioneiro em ensinar no Rio de Janeiro o Design de Exposições (ou de Exibições), assim se produziu uma definição dessa prática e seus fundamentos; como atua esse profissional do design; com que outras categorias profissionais ele se relaciona; os vários tipos de espaço onde se pode trabalhar com exposições; o que complementa as exposições tal como a folheteria, o material de divulgação, os catálogos. Ainda, quais as ferramentas usadas para a atividade; quais os materiais empregados no dia a dia; o uso de escala; o desenho de planta; a construção de maquetes; a noção da dimensão e o levantamento do espaço; a relação do espaço com a dimensão humana e quais as sensações que o espaço pode produzir nas pessoas; a iluminação a ser empregada. Tudo isso sendo considerado, evidentemente, de acordo com o tipo de exposição que se ia montar.

Finalmente questionada se nossa entrevistada sabia se tal curso era único no Rio de Janeiro, Cintia Kury explicou que no passado teve notícia de um curso ministrado na Pontifícia Universidade do Rio de Janeiro (PUC-Rio), mas cujo enfoque se concentrava em outras disciplinas, como por exemplo, os diversos tipos de arquiteturas de exposições; a história das exibições desde seu período mais clássico até o surgimento da ideia do cubo branco; as modalidades de exposições dentre elas as de arte ou as históricas. Parecia-lhe que o curso da PUCRio tinha um viés mais teórico, não voltado para as questões da produção de exibições na prática e do Design de Exposição propriamente dito.

$\mathrm{Na}$ atualidade, Cintia Kury acredita que o Design de exibições permanece não sendo ensinado no Rio de Janeiro. Segundo a entrevistada, o que se oferece agora são cursos voltados para a curadoria de arte (citou o do Parque Lage) que versam sobre conceitos e diferentes períodos da produção artística e sobre coleções de arte. Esses cursos não se dedicam à técnica de trabalhar o espaço ou à sua relação com o objeto exposto. Também não abordam conteúdo específico do Design de Exibições como mobiliário; suporte de vitrines ou de esculturas; 
circulação dos visitantes individualmente ou em grupos, o uso da cor e como ela pode servir para orientação de circulação; sistemas de iluminação, conforto visual e sonoro, incidência de vento proveniente de ar-condicionado nos objetos expostos, insolação no ambiente expositivo, combate aos insetos, localização dos extintores de incêndio, enfim fundamentos desde os mais sofisticados até os mais elementares de design.

A entrevistada se lembrou, entretanto, do curso sobre Design de Exposição, denominado A Construção do Espaço Expositivo ${ }^{33}$, que ministrou conjuntamente com Luis Alberto Garcia Zúñiga, em 2014, no Museu de Arte do Rio (MAR). Cintia Kury informou que poucas pessoas que participaram do curso eram designers. A turma constituiu-se, majoritariamente, de professores integrantes da rede pública estadual e municipal. Esses professores usavam o espaço das escolas em que lecionavam para expor trabalhos de arte produzidos pelos alunos, preocupando-se em expor com mais dignidade e com um olhar próprio de exposições essa produção, a fim de valorizá-la.

Confirmou-se a impressão de nossa entrevistada por meio de breve busca na internet sobre a existência de cursos de Design de Exibições no Rio de Janeiro, universitários ou não ${ }^{34}$. Encontrou-se como resultado dessa sucinta pesquisa que a Universidade de São Paulo (USP) oferece no Programa de pós graduação Interunidades em Museologia a disciplina Comunicação e Expografia. Na Universidade Veiga de Almeida, no Rio de Janeiro, é ministrada a matéria Expografia nos cursos de pós graduação em Cenografia ${ }^{35}$; Design de Interiores ${ }^{36}$; Visual-Merchandising ${ }^{37}$. No SENAC de São Paulo é ensinada a disciplina Museografia, Expografia e Comunicação ${ }^{38}$ na pós graduação em Curadoria em Arte. Ainda em São Paulo, no Belas Artes, há a pós graduação em Gestão de Coleções, Curadoria em que se ensinam as disciplinas Montagem de Exposições:

\footnotetext{
${ }^{33} \mathrm{http}: / /$ www.museudeartedorio.org.br/pt-br/evento/curso-a-construcao-do-espacoexpositivo-3

${ }^{34}$ https://criticaexpografica.wordpress.com/2015/10/01/como-se-forma-um-profissional-deexpografia/

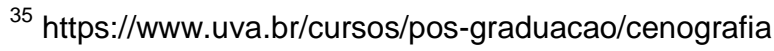

${ }^{36}$ https://www.uva.br/cursos/pos-graduacao/design-de-interiores

${ }^{37} \mathrm{https}: / /$ www.uva.br/cursos/pos-graduacao/visual-merchandising

${ }^{38} \mathrm{http}: / / w w w . s p . s e n a c . b r / j s p / d e f a u l t . j s p ? n e w s I D=D Y N A M I C$, oracle.br.dataservers.CourseDa taServer, selectCourse $2 \&$ course $=1$ 9560 \&template $=397$.dwt\&unit=SCl\&testeira $=303$
} 
processos; e Concepção, Planejamento de exposições..$^{39}$ E na Faculdade Paulista de Artes é oferecido o curso de especialização em Curadoria e Montagem de Exposições $^{40}$.

Conjectura-se na presente pesquisa que um possível motivo para o Design de Exibições integrar tão raramente a grade das disciplinas ministradas em cursos e em universidades de Design no Rio de Janeiro possa ser a sua natureza interdisciplinar. Segundo escreve Albert Woods (WOODS, in.: KLEIN: 1986: 08), quem trabalha com Design de Exibições sabe tratar-se de disciplina à parte das outras do Campo do Design por envolver conhecimentos de arquitetura, de design de interiores, de design gráfico, de fotografia, de mídias audiovisuais e de teatro. Afirma ainda que a disciplina não confere primazia ao Design, mas sim à teoria da comunicação. ${ }^{41}$ Conclui-se, portanto, que o ensino da disciplina pode mostrar-se um tanto quanto complexo, exigindo o aporte de profissionais de múltiplas, porém afins, áreas de conhecimento.

Outro aspecto que poderia justificar o reduzido, diga-se quase inexistente, ensino do Design de Exibições em universidades ou cursos de design no Rio de Janeiro seria a indefiniçãa sobre o objeto de estudo do Design. Fabiana Heinrich, (HEINRICH \& CIPINIUK, 2013: 59.) ${ }^{42}$ constata esse fato em sua dissertação de mestrado. Livros e trabalhos publicados por Stephen Vial (VIAL, 2014: passim), Alain Findeli (FINDELI, 2001: passim), ou por Bruno Latour (LATOUR, 2008: passim), por exemplo, demonstram o esforço dos referidos autores em compreender o alcance atual do que seja o Campo do Design, desenvolver-lhe uma teoria científica ou uma filosofia, definir uma ética de atuação do profissional da área. Assim, um elemento relevante para o presente trabalho e que é percebido como ainda em constante construção diz respeito à definição de metodologia do projeto no Campo. Embora tal definição não figure como escopo do presente

\footnotetext{
${ }^{39} \mathrm{http}: / /$ www.belasartes.br/pos-graduacao/?pagina=cursos\&curso=gestao-de-colecoescuradoria-e-mercado

${ }^{40}$ http://fpa.art.br/web/pos-graduacao-curadoria-e-montagem-de-exposicoes/

${ }^{41}$ Anyone working in the field of exhibition design is aware that it is set apart from the other design disciplines. [...] exhibition design involves a blend of architecture, interiors, graphics, photography, audio-visual media, and theatre. But exhibition work is not primarily about design. It is about communication.

42 Como não é possível fugir às questões relativas à definição de um campo ainda e em constante construção; [...].
} 
trabalho, ela merece ser abordada, ainda que superficialmente, pois parece complementar a possível explicação da ausência quase que total do ensino do Design de Exibições em universidades e cursos de Design no Rio de Janeiro. Isso porque, em se conseguindo definir qual a especificidade da metodologia projetual no Campo do Design, pode-se partir para a busca da especificidade, se existente, dessa mesma metodologia quando aplicada ao Design de Exibições. A demonstração de tal especificidade poderia servir ao propósito de ver mais expandido o ensino do Design de Exibições em nossas universidades e cursos de Design.

Segundo afirmam Heinrich e Cipiniuk (HEINRICH \& CIPINIUK, 2013: 59) podemos observar o quão amplo é o espectro da noção de metodologia de projeto, afinal esta se relaciona com vários outros conceitos do campo e muitas vezes é até mesmo confundida com muitos deles. Tal afirmação filia-se à corrente que conclui pela indefinição ainda reinante na teoria do Design quanto à definição de metodologia do projeto, não logrando também descobrir sua especificidade quando aplicada ao Campo. Embora, por enquanto, essa opinião seja defendida por minoria da doutrina nacional que reflete sobre o tema, ela mostra-se amparada por estudos desenvolvidos internacionalmente. Novamente Heinrich e Cipiniuk (HEINRICH \& CIPINIUK, 2013: 59) tratam do assunto citando definição proposta por Fuentes em 2006. Segundo escrevem (HEINRICH \& CIPINIUK, 2013: 58-59):

[...] outros autores, em distintas publicações discorrem sobre possíveis definições para metodologia de projeto. Um exemplo seria Fuentes (2016: 14-15) que na publicação A prática do Design Gráfico (2006) define a metodologia de projeto no campo do Design como aquela que tem por objetivo aumentar o conhecimento das coisas e dar maior sustentação ao ato criativo, permitindo ampliar os pontos de vista sobre um determinado problema, aumentando o seu conhecimento e facilitando uma perspectiva criativa global até a sua resolução. Com efeito, de acordo com o autor, todo método seria, ao mesmo tempo, um procedimento intelectual (aspecto semântico, cognitivo e informativo) e um procedimento operacional, manual (aspecto pragmático, material e técnico), com vistas à consecução de um resultado que foi predeterminado e com uma adequada precisão, entre uma atividade individual e uma atividade que é quase sempre coletiva e que caracteriza não apenas a prática do Design, mas sim a inúmeras disciplinas.

Concorda-se com a afirmação de que a prática da metodologia do projeto faz-se presente não apenas no Campo Design, mas certamente também na 
Engenharia ou na Arquitetura, na Cenografia e em grande maioria das carreiras ligadas às artes visuais. Ora, conclui-se que a falta de caracterização, pelo menos até o presente momento, de qual seja a especificidade da metodologia do projeto no Campo do Design se comparada com aquela de outras áreas do saber humano, mostra-se um complicador para a definição dessa especificidade também quanto ao Design de Exibições. Acredita-se que tal indefinição pode reforçar a relutância que se observa quanto ao ensino dessa disciplina pela maioria das universidades e cursos de design no Rio de Janeiro.

No capítulo seguinte serão relatos exemplos da prática do Design de Exibições em museus e centros culturais do Rio de Janeiro, tendo-se conferido atenção especial ao Museu da República e ao Museu de Arte Moderna (MAMRio) pela relevância dessas instituições para o desenvolvimento da atividade tanto no referido estado como em âmbito nacional. 


\section{Design de Exibição no Rio de Janeiro. O exemplo do Museu da República.}

Cintia Kury informou que ela e seu marido, Luis Alberto Garcia Zúñiga, trabalhando juntos na área de exposições em museus, presenciaram um momento de transformação no papel dos museus, que começou na década de1980 no Brasil. A entrevistada credita essa mudança ao possível fomento dado pela Fundação Nacional próMemória criada por lei aprovada pelo Congresso Nacional e fundada pelo designer gráfico Aloísio Magalhães, que segundo ela, tinha um pensamento muito à frente de seu tempo, tendo por referência modelos de museus americanos e europeus. Assim, tal como já vinha sendo praticado internacionalmente à época, a noção de comunicação visual praticada na área do design entrou nos museus brasileiros com muito mais força, não só no tocante à comunicação com o visitante, mas também no que se referia aos setores educativos dos museus.

Cintia Kury explicou que por conta de Aloísio Magalhães ter um contato muito estreito com as escolas de design, ele começou a divulgar a possibilidade, inicialmente do design gráfico, de atuar em exposições em museus, seja na produção de catálogos, seja na produção de folheteria em geral. Aproveita-se para se acrescentar o fato de ele ser uma espécie de mito da historiografia do Design no Brasil, celebrado unanimemente pelos inúmeros trabalhos que realizou durante o período da ditadura militar brasileira, quando chegou a ser Secretário de Cultura. Cintia Kury explicou que os museus se tornavam lugares de pesquisa e houve uma produção de pensamento dentro do Campo de que isso tinha que ter uma "cara", uma identidade. Foi quando pela primeira vez se falou em identidade visual dentro dos nossos museus. Daí, segundo nossa entrevistada, o museu brasileiro começou a se preocupar em como ter seu nome transformado em uma "marca", e em como explorar produtos com essa marca, a exemplo do que já fazia o Museum of Modern Art (MOMA) de Nova Iorque e diversos outros museus pelo mundo afora. 
$\mathrm{O}$ artigo intitulado Design de informação: os sistemas expositivos projetados por Bergmiller, publicado na Revista designbrasil, em 14 de junho de $2013^{43}$, alerta para o espírito empresarial que passava a influenciar os museus de arte brasileiros a partir da década de 1940. O texto relata:

No Brasil, nos finais dos anos 1940, a intenção da formação de museus de arte moderna começou a se delinear impulsionada pelo mesmo espírito empresarial, que envolvia a cena moderna norte americana, concretizada no Museu de Arte Moderna de Nova Iorque MOMA (Castillo, 2008). Como conta Amaral (1988), o MASP, o MAM do Rio de Janeiro e o MAM de São Paulo possuíram origem comum, e todos eram dependentes de mecenas.

A questão do museu como uma marca e seus produtos foi abordado também em entrevista realizada com a professora do departamento de arquitetura da PUCRio, Ana Luísa Nobre, ao defender que a exposição tem o momento de sua elaboração, o momento em que está na vitrine, por assim dizer, e tem seu momento posterior, isto é, a marca e os produtos que ela deixa.

Cintia Kury também relatou a experiência inovadora que se realizava no MAM Rio àquela época, por parte do seu departamento de design, que deu uma ordenação para o sistema de montagem de exposições de arte na instituição carioca. Ela considerou que o instituto foi fortemente influenciado por Karl Heinz Bergmiller, designer formado pela escola de ULM na qual havia sido aluno de Max Bill, que dirigia a equipe de designers que montavam exposições do MAM e que era professor da ESDI.

Fazendo-se um adendo a entrevista concedida por Cintia Kury, cita-se novamente o artigo da Revista designbrasil. ${ }^{44}$ A matéria alude ao fato do percurso do MAM-RJ mesclar-se com as histórias da implantação do campo profissional do desenho industrial no Brasil. Publica que no início da década de 1950 chegou ao país Max Bill, artista concretista, incentivador da formação de uma escola superior de desenho industrial no Rio de Janeiro. Tal escola, segundo os ideais de Max Bill, deveria ser criada nos moldes da escola modernista de Ulm.

\footnotetext{
${ }^{43} \mathrm{http}$ ://www.designbrasil.org.br/entre-aspas/design-de-informacao-os-sistemas-expositivosprojetados-por-bergmiller/disponível em 5/11/2016.

${ }^{44}$ http://www.designbrasil.org.br/entre-aspas/design-de-informacao-os-sistemas-expositivosprojetados-por-bergmiller/
} 
Inicialmente pensada para o próprio MAM, a ideia acabou se transformando na Escola Superior de desenho Industrial - ESDI, implantada em1963, sob o governo de Carlos Lacerda. Em 1968 o MAM montou um instituto, o IDI, Instituto de Desenho Industrial. Karl Heinz Bergmiller, chegado ao Brasil em 1958, designer e ex-aluno de Max Bill em Ulm, foi um dos mentores da ESDI. Coordenou o Instituto de Desenho Industrial projetando sistemas expositivos e gerenciando, a partir de 1968, as exposições apresentadas pelo museu em sua nova sede, no aterro do Flamengo, projetada por Affonso Eduardo Reidy.

Após 1968 e até o ano de 1978, posteriormente ao fechamento do Instituto de Arte Contemporânea (IAC) de São Paulo, assunto o qual se tratará a seguir, funcionou no MAM o Instituto de Desenho Industrial (IDI). Ethel Leon (LEON, 2012), em curta menção ao sistema de suportes criados por Bergmiller para o MAM, escreve que desde a inauguração do MAM, com a exposição de Lasar Segall, Bergmiller se encarregara de projetar um sistema expográfico flexível para o museu.

Cintia Kury relata que nesse ponto o MAM foi absolutamente pioneiro aqui no Rio de Janeiro. Explica que Bergmiller projetou para o MAM do Rio de Janeiro um sistema de suportes por meio de painéis por ele desenhados e em uso até os dias de hoje. A entrevistada explica ainda que Bergmiller criou também um sistema de esticar os cabos para pendurar os quadros e deu os gabaritos de como esse suporte deveria ser montado. Enfim, Bergmiller e sua equipe projetaram a maneira e as possibilidades de ocupação do MAM.

Ana Luísa Nobre, no decorrer da entrevista, também se lembrou desse sistema de suportes de exposições constituído de painéis e de outros elementos, desenvolvido experimentalmente pelo MAM ao final da década de 60 e início da década de 1970. Segundo a entrevistada, tratava-se de uma tentativa de se criar alguma coisa não necessariamente nacional, posto que a linguagem utilizada por Bergmiller era muito internacional, mas que guardasse relação com uma realidade específica brasileira, qual seja, o alto custo das montagens de exposições de arte e a falta de recursos que normalmente assola nossas instituições culturais. Por isso, reaproveitar é importante. Ela descreveu como Bergmiller e Goebel Weyne elaboraram juntos um sistema de suportes de exposições que em tese pudesse abrigar qualquer tipo de exibição. Explicou tratar-se de algo difícil de se projetar tendo-se em vista a diversidade de cada exposição, porém muito desejável já que 
o custo de um projeto de exposição e de sua montagem por vezes é maior do que o valor das próprias obras de arte expostas. Trata-se de um custo que costuma ser bem alto dentro do custo total da exposição. A entrevistada que coordena o departamento educativo do Instituto Moreira Salles informou que o instituto atualmente busca o reaproveitamento, desejando desenvolver um sistema de suportes constituído possivelmente por elementos seriados, que permitam que se possa montá-los, juntá-los, guardá-los, reutilizá-los.

Ethel Leon (LEON, 2014) lembra que iniciativa similar também havia sido anteriormente realizada em São Paulo pelo Instituto de Arte Contemporânea (IAC), escola de design mantida pelo Museu de Arte de São Paulo de 1951 a 1953 (LEON, 2012), com os projetos de Lina Bo Bardi, de forma que o museu paulista também se tornou referência nacional quanto à inovação de seu sistema de suportes expositivos.

Cintia Kury prosseguiu a entrevista afirmando que os ditos suportes expositivos, desenvolvidos pelo departamento de design do MAM, conferiram ao museu ordenação para o sistema de montagem e isso serviu de inspiração para outros espaços, pois estamos falando de uma época em que os museus trabalhavam mais com equipes internas cujos profissionais muitas vezes não tinham formação em design ou mesmo uma formação técnica oriunda de um curso superior. Cita-se o exemplo famoso do costureiro e estilista, célebre por sua participação nos carnavais cariocas, Clóvis Bornay, que foi "museólogo" do Museu Histórico Nacional ${ }^{45}$. É preciso lembrar ainda que nesse período os museus brasileiros não eram tão abertos às exposições vindas de fora, normalmente exibiam o próprio acervo. $\mathrm{O}$ escasso intercâmbio de práticas de montagens de exibições entre museus nacionais e internacionais, no período considerado, também impossibilitou a difusão desse tipo de organização em grande parte das instituições museais nacionais.

Cintia Kury atuou na área de Design de exibições desde 1984. Realizando projetos em parceria com seu marido Luis Alberto Garcia Zúñiga, trabalharam juntos como profissionais autônomos ou fazendo parte dos quadros do Museu da República, até se aposentarem em 2013. Participaram ambos da criação do setor de exposições que cuidava justamente da distribuição e da ocupação dos espaços

\footnotetext{
${ }^{45}$ https://www.museus.gov.br/tag/clovis-bornay/
} 
do mencionado museu, desenvolvendo um mobiliário de exposição - painéis, suportes, vitrines - para atender ao espaço específico do museu. Quando foi perguntada se eram exposições de arte que montavam, Cintia Kury respondeu afirmativamente. Explicou que o museu abrigava exposições temporárias de arte tantas vezes internacionais e expunham alguns trabalhos de arte do acervo do museu, mas que de fato, o predominante eram exibições que se atinham às questões históricas ou do acervo de objetos pertencentes ao Museu da República, mas que isso contribuiu para a oportunidade de experimentar muitas coisas.

Ao ser indagada se a maneira de organizar o espaço mudava muito isso que era uma exibição de arte em relação a uma exibição de objetos históricos, Cintia Kury disse que sim, pois precisava mudar a "linguagem" que era usada, justamente para que o público voltasse e o museu não ficasse engessado. Embora a resposta que tenha fornecido não tenha deixado muito claro o que seria, ou do que tratava esse tipo de "linguagem" que era empregada, qual a sua especificidade, no decorrer da entrevista a resposta foi sendo dada com exemplos dos projetos executados.

A designer nos disse que, em parceria com Luis Alberto Garcia Zúñiga, realizou exposições interessantes não apenas no Museu da República, mas também como free-lancer porque nos anos oitenta e noventa ocorreu uma espécie de boom cultural, quando abriram todos os centros culturais do Rio de Janeiro, tais como o Centro Cultural do Banco do Brasil (CCBB), o Centro Cultural dos Correios, a Caixa Cultural e o Paço Imperial. Para ela, isso mudou sua "linguagem". Juntos montaram exposições em estações de metrô, universidades, shopping centers, bancos, empresas privadas e foi uma época em que havia muito patrocínio para exibições. Daí o casal viajou montando exibições também fora do Rio.

Cintia Kury relatou que Luis Alberto Garcia Zúñiga havia sido agraciado com uma bolsa de estudos na Alemanha para complementar sua formação de designer pela ESDI. Foi, portanto, na Alemanha que tomou contato com a modalidade do Design de Exposições. Quando voltou ao Brasil, foi trabalhar no departamento de design do MAM e já mantinha contatos na Alemanha que lhe permitiram, ainda nos anos 70, que exercesse também a função de comissário de exposições de arte na América Latina para o governo alemão (o termo comissário aqui tem o mesmo sentido que possui em francês, isto é, curador). Naquela época, 
segundo informado por Cintia Kury, somente os alemães mandavam exposições itinerantes para o Brasil, geralmente exposições grandes totalizando de dois a três contêineres. Tais exposições alemãs viajavam com tudo, mobiliário, equipamento, ferramentas, projeto já definido. Zúñiga fazia a ocupação dos espaços conforme a determinação do briefing e a exposição, conforme o lugar para onde ela ia, podia ser completa ou apenas um recorte. Sendo assim, Zúñiga também fazia o papel de curador ou de comissário nos lugares onde a exibição era montada. Viajava a América Latina inteira e o Brasil inteiro. Contudo, as exposições eram geralmente no Rio de Janeiro, São Paulo e Brasília e depois elas percorriam a América Latina passando por Buenos Aires, Santiago, Montevidéu. As exposições viajavam de navio. Zúñiga ia até as cidades, montava a exposição e a deixava pelo período de sua duração, depois voltava e embalava ela toda de novo, obedecendo à logística que envolve o processo de embalagem de contêiner, e então despachava a exposição para o país seguinte. Quando havia a necessidade de um recorte da exposição, Zúñiga escolhia quais peças seriam exibidas, após conversar com a equipe do museu e dependendo da característica do museu, do tipo de visitante, da cidade na qual a exposição seria montada.

Toda essa experiência amealhada internacionalmente por Zúñiga contribuiu positivamente para o desenvolvimento de projetos e montagens de exposições que o casal realizava no Museu da República, e também no trabalho que realizavam no setor educativo do museu. Como relatou Cintia Kury, essa foi uma época muito ativa do museu e de muita experimentação. $\mathrm{O}$ casal realizava exposições somente para crianças em determinados períodos, ou direcionadas a um público mais leigo e outras exposições mais aprofundadas direcionadas a um público mais informado. Assim foram realizando inúmeras exibições nas quais os setores de pesquisa, de museologia, do serviço educativo e de design do museu atuavam concomitantemente e de maneira integrada.

Por meio desse relato, ficou-se sabendo com maior clareza que várias "linguagens" foram essas que inicialmente Cintia Kury havia mencionado. Ela explicou que era um momento em que podiam experimentar trabalhar tanto com uma "linguagem" mais formal de textos explicativos em painéis, exposição tridimensional e objetos tridimensionais, como com a introdução progressiva de uma, diga-se nova para a época, "linguagem" de vídeo, de projeções, de interatividade, de áudio, de iluminação que eram modalidades de auxílio às 
exibições que o museu ainda não havia adotado. A maneira tradicionalmente adotada de se exibir arte em museus, segundo Cintia Kury, era muito "sacralizada", quase que intocável. Enfim, reproduzir coisas para que as crianças pudessem mexer e promover meios e atividades que trouxessem o público para mais perto do acervo não eram ainda praticados pelo referido museu, até então.

Tudo indica que se tratava de realizar uma espécie de cenografia. Cintia Kury afirmou que o casal trabalhava procurando, sempre que possível, proporcionar essa mistura dos vários setores do museu, ouvindo o que cada profissional das diferentes áreas tinha para dizer de suas viagens pelo Brasil ou pelo exterior. O Museu da República também exigia que trabalhassem com datas festivas, algo que buscavam fazer sempre de maneira diferente, isto é, tal como explicou, para não ficar algo careta.

Perguntada se houve uma forte mudança na cenografia das exposições do Museu da República nas décadas de 1980 e 1990, Cintia Kury mencionou a exposição permanente projetada e montada por Gisela Magalhães e pela equipe de design, em 1980. Tal exposição foi considerada revolucionária, contudo, posteriormente, o departamento de design percebeu que, ao mesmo tempo, tinha sido criada uma série de problemas para a conservação do prédio. A exibição projetada por Gisela Magalhães havia bloqueado muitas paredes e escondido um pouco da arquitetura. Explicou que essa era uma característica da prática museal da época - construir uma espécie de caixa, para dentro dela surgir a exposição - a caixa preta e a caixa branca.

Cintia Kury relatou ainda que Gisela Magalhães também experimentou o uso de backlights e de áudio. Enfim, tratou-se de uma cenografia, termo empregado pela entrevistada, muito mais ousada para aquela época. Gisela Magalhães havia projetado elementos fora de vitrines, com coisas que os visitantes podiam passar por dentro ou atravessar e também muitos enfeites distribuídos pelo espaço expositivo. Refletindo retrospectivamente, a entrevistada acredita que aquela exibição pode ser hoje entendida como "um pouco 'over", tal como mencionou. Lembrou que havia muita "experiência" 46 sendo realizada ao

\footnotetext{
${ }^{46}$ Aqui o termo experiência está entre aspas, pois o emprego desse termo nos dias de hoje é recorrente. Muitos designers afirmam que existe no Campo do Design uma nova prática: o "experience design", uma noção que afirma que a prática do design é produzir uma "experiência". Com a devida vênia, não se concorda com essa noção, pois tal como a noção
} 
mesmo tempo, em cada sala acontecia alguma coisa. Mas de qualquer maneira, era algo muito inovador para a época.

Aqui se pede permissão para se fazer um adendo à entrevista que se vem transcrevendo, lembrando-se do trabalho de Gisela Magalhães, arquiteta que dedicou décadas de sua carreira à montagem de exibições. Sua linha era justamente a que insere os elementos exibidos em um ambiente cenográfico, rico em narrativa. Julga-se pertinente dizer que tenha sido ela uma das pioneiras nesse tipo de abordagem das exibições no Brasil. Uma longa matéria sobre seu trabalho foi publicada em 1997 pela Projeto Design, Revista de Arquitetura, Interiores e Design. $^{47}$

Gisela Magalhães obteve sua graduação em arquitetura no ano de 1958 pela Universidade do Brasil (atual Universidade do Rio de Janeiro) e trabalhou com Oscar Niemeyer, Lúcio Costa e Alcides da Rocha Miranda. Residiu em Brasília nas décadas de 1960 e 1970. Na década de 1970, trocou a arquitetura pela atividade de montagem de exposições e em Brasília montou suas primeiras mostras a partir de 1973. Foram elas: Sete Brasileiros e seu Universo (1973), Kharó (1974), O Rio, Carrancas do São Francisco (1975), Artesanato da Região Centro-Oeste (1976), Inventiva Arte Índia Brasileira (1978). ${ }^{48}$

Segundo a matéria publicada, o trabalho de Gisela Magalhães era ancorado em quatro pilares quais sejam: saber lidar com o espaço; possuir uma ampla cultura geral que facilitava a abordagem dos temas; o interesse pela política; a intuição para estimular a emoção e a memória das pessoas, levando-as à reflexão crítica da realidade.

Assim, ainda na fase de concepção da exposição, Gisela Magalhães lia e estudava tudo o que podia sobre o tema da exposição. Na fase do planejamento, ela buscava por novas formas de apresentar os elementos expostos e assim surpreender o visitante. Emocioná-lo. Para tanto, muitas vezes a arquiteta recorria

\footnotetext{
de "social design", acredita-se que qualquer prática social necessariamente produz uma experiência qualquer, assim como todas as modalidades de design são para sociedade, isto é, são sociais.

47 Projeto Design, Revista de Arquitetura, Interiores e Design. Arquitetura transitória usa espaço para recontar a história, emocionar o público e fazer política. $\mathrm{N}^{0} 112$, setembro de 1997, Arco Editorial Ltda., p. 78-85.

48 Ibid., id., id.
} 
ao humor, ao choque ou a símbolos quando da montagem da exposição. Ainda sobre essa última fase, a da montagem, Gisela Magalhães a realizava sempre com a intenção de produzir um resultado instigante, subversivo e político. Sou um ser político e faço política usando o espaço para contar a história, como explicava a arquiteta para definir sua personalidade e sua busca profissional. ${ }^{49}$

Por intermédio da emoção vivida pelo visitante, Gisela Magalhães queria provocar a reflexão sobre a realidade. Ela acreditava que o caminho para o cérebro passava pela emoção ${ }^{50}$ e defendia que não bastava mostrar, era preciso envolver. Transformava, portanto, o espaço em espaço dramático e o visitante era assim atraído pela informação. A dramaticidade era reforçada pela iluminação, pelo som, pela música, por vídeos, pelas cores. ${ }^{51}$ Tudo isso aliado à certeza de que o público não apenas vê a mostra, mas é parte integrante e dela participa ativamente. Tinha, portanto, por lema as palavras envolvimento e participação. Finalmente, Gisela Magalhães também se dedicava a garantir uma visitação confortável ao visitante, pois como gostava de repetir: Ninguém sai de casa para ler em pé. Por esse motivo, ela evitava em suas exposições o uso de painéis ou longos textos explicativos. ${ }^{52}$

Gisela Magalhães montou diversas exposições no Rio de Janeiro, muitas delas, tal como já foi citado, no Museu da República, localizado no antigo Palácio do Catete, casarão que por muitos anos serviu de sede da Presidência do Brasil. A exposição A Ventura Republicana ${ }^{53}$ concebida por Gisela Magalhães e pesquisa realizada pelo historiador Joel Rufino dos Santos, reuniu cerca de mil peças do acervo do palácio que foram expostas junto a painéis fotográficos, projeções de vídeos e instalações cênicas. Montada no terceiro andar no museu em dezembro de 1996, expressou a visão de Gisela Magalhães de que cada visitante faria a "leitura" que quisesse daquilo que estava sendo exposto. Para tanto se utilizou de frase da personagem Riobaldo do livro Grande Sertão Veredas, escrito por Guimarães Rosa: o senhor pense. O senhor ache. O senhor ponha enredo ${ }^{54} \mathrm{Nas}$

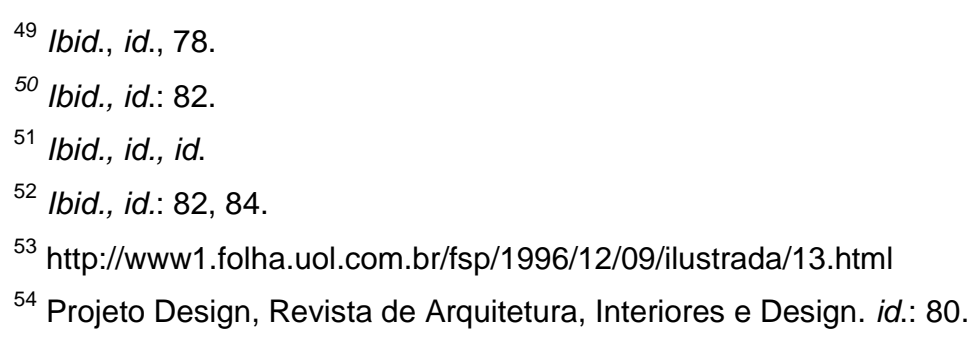


salas dessa exibição, a história da república brasileira foi apresentada por temas. Como explicou Gisela Magalhães, É um cenário que tem de contar um conceito. Cada um vai entender conforme sua concepção sobre a vida. ${ }^{55}$

Acreditando no potencial de compreensão do povo brasileiro, Gisela Magalhães atraía para suas exposições quantidade expressiva de visitantes, tal como a marca de cerca de cinquenta mil pessoas em um mês para a exposição A Paixão Segundo Clarisse Lispector apresentada no Centro Cultural do Banco do Brasil do Rio de Janeiro em 1992 e a exposição Fala, Getúlio, montada em 1994 no Museu da República e que atraía diariamente cerca de duas mil pessoas. ${ }^{56}$

Novamente voltando à entrevista fornecida por Cintia Kury, ela comentou que no processo de planejamento das exibições no Museu da República contava com o contato diário com sua equipe interna de trabalho. Conhecia, por exemplo, quem se encarregava da limpeza dos espaços expositivos ou quantas pessoas estavam incumbidas dessa limpeza. A entrevistada reafirmou a extrema importância disso, já que quem faz a manutenção da exposição no cotidiano é a equipe do museu. Assim, questões como, por exemplo, a limpeza de ambientes escuros ou com que frequência se faz a troca de lâmpadas queimadas no decorrer da exposição eram facilitadas pelo fato de que trabalhava profundamente inserida dentro da miríade de minudências existentes no museu. No caso do Museu da República havia esse fator facilitador, pois, a instituição já tinha seu modus operandi, já possuía as suas características, seu próprio acervo constituído respeitando o recorte disso que é um museu de uma república, além do prédio e de sua rica arquitetura.

A nossa entrevistada afirmou, entretanto, que em centros culturais o mesmo geralmente não acontecia, afinal as exposições eram temporárias e tais instituições não contavam (e muitas ainda não contam) com uma equipe permanente, dedicada aos assuntos relativos às exibições. Questionada sobre quais são as categorias de profissionais que normalmente atuam em conjunto com o designer de exibições em museus, Cintia Kury afirmou ser impossível elencar um rol preciso. Explicou, contudo, que não se monta exposições de qualquer natureza sem uma equipe diversificada.

\footnotetext{
${ }^{55}$ http://www1.folha.uol.com.br/fsp/1996/12/09/ilustrada/13.html, disponível em 14/11/2016.

${ }^{56}$ Projeto Design, Revista de Arquitetura, Interiores e Design. id.: 84.
} 
Continuando a falar sobre sua larga experiência como designer de exibições do Museu da República, Cintia Kury referiu-se ao desafio com o qual geralmente a equipe de design se via confrontada. Trata-se de o fato do Museu da República ser um prédio que não foi originalmente pensado e construído para ser um museu, mas sim, uma residência de um nobre do Império brasileiro e que com a República, passou a ser residência presidencial. O mencionado museu ocupa o Palácio do Catete, prédio que por si só atrai a visitação, por ser um belíssimo exemplo da arquitetura eclética ou historicista da segunda metade do século XIX, quando foi construído pelo Barão de Nova Friburgo. O casal de designers sabia que esse fato não poderia ser desconsiderado. Cintia Kury relatou, por exemplo, o fato do segundo andar do prédio ser um constante desafio a ser vencido por sua equipe por ser permanentemente montado como fora a residência do presidente da República do Brasil quando a capital do Estado era o Rio de Janeiro. Explicou que o terceiro e o primeiro andar, os quais eram os mais empregados para a organização das demais exposições elaboradas pela equipe de design, tinham que conviver com esse segundo andar, pois os visitantes eram obrigados a atravessá-lo para chegar ao terceiro andar. Portanto, existiam questões de circulação que não eram passíveis de serem resolvidas. Uma exposição que exigisse o uso do terceiro andar, naturalmente reclamava por um elo de ligação com os outros espaços, no caso, uma escada monumental de ferro no centro do prédio que o visitante precisa vencer para que possa circular no prédio. Tal escada, por si própria, rompia com a continuidade da exposição que se propunha desde o primeiro andar, enfraquecendo potencialmente o vínculo que o visitante já compartilhasse com tal exposição. Carregar a "linguagem" da exibição do primeiro andar para cima, produzia, necessariamente, uma espécie de parada ou corte na visitação.

Outro desafio descrito pela entrevistada era a presença do salão ministerial, que representava mais uma quebra na planta nas salas de exposição localizadas no primeiro andar do museu. Explicou que as salas desse andar deságuam exatamente no mencionado salão ministerial. Essa característica do espaço criava para a equipe de design a complicada e, diga-se de passagem, até mesmo incontornável, tarefa de integrar tal salão à circulação da exibição do primeiro e terceiro andar.

Ciente desses desafios que conduziam à ruptura da continuidade das exposições montadas e que potencialmente proporcionavam o enfraquecimento do interesse dos visitantes, a equipe de design, no decorrer dos anos, optou por fazer 
maquetes das salas do museu para que pudessem ter em mãos a parte tridimensional, volumétrica ou física do espaço quando da concepção e montagem das futuras exibições. Essas maquetes eram usadas para que as equipes dos demais setores do museu, por exemplo o da museologia, o da segurança ou do educativo, entendessem claramente o espaço que dava unidade às exibições e os problemas da circulação de seus visitantes. Cintia Kury justificou o apelo ao uso das maquetes pelo fato de que aquilo que aparecia tridimensionalmente como representação do espaço das exibições na tela do computador era ininteligível para as demais equipes do museu. Afirmou que só o nosso olho que é treinado vê, referindo-se a equipe de design do museu.

Cintia Kury, desse modo, nos explicou que uma exibição é essencialmente uma questão operacional, ou seja, funcional ou técnica. Ela acredita também que a diversidade dos aspectos técnicos que a constituem deveriam ser objeto de maior discussão. Citou a realidade nacional na qual grande parte dos museus não possui seguranças ou monitores que possam ficar nas salas a fim de salvaguardar os bens expostos ou as estruturas expositivas montadas. Há que se ter em mente que o pessoal da segurança ou o monitor precisa ter a visão da unidade espacial das salas, permitindo-lhes percorrê-las sem obstruções, não se pode criar bloqueios que impeçam a realização da segurança da exibição. Cintia Kury tentou esclarecer que havia muita visitação de escolas, que vinham com turmas inteiras de uma só vez e que mesmo que acompanhadas do pessoal do serviço educativo do museu, essa questão, a dos espaços históricos do museu que precisavam ser preservados com segurança específica, para dar-lhes proteção, se impunha insistentemente. Os mesmos cuidados eram exigidos para as demais exibições montadas no museu. Cintia Kury disse acreditar que hoje em dia, nos museus nacionais mais novos, essa questão da segurança já é mais bem definida, com a presença constante de guardas de salas e de monitores, mas alertou que nos museus federais e estaduais essa escassez de pessoal ainda continua.

Ainda quanto aos aspectos técnicos das exibições em museus que merecem atenção, Cintia Kury prosseguiu opinando que o pessoal que faz limpeza e manutenção de exposição também deve ser treinado de tempos em tempos, há que se fazer esse treinamento inclusive no tocante à montagem, tal como quais seriam os produtos para a limpeza do ambiente de exposição que podem ser usados, em qual tipo de vitrine podem ser empregados. Afirmou que as vitrines precisam ser 
pintadas com tintas que permitam a limpeza, pois os pés dos visitantes vão encostando-se aos painéis ou vitrines que precisam se manter limpos. Cintia Kury explicou que no Museu da República eram ministradas, portanto, aulas práticas para esse setor e que juntos percorriam as exposições, explicitando-se os problemas que ocorriam.

Cintia Kury relatou que havia ainda o desafio do vento expelido pelas saídas de ar condicionado das salas de exibições no Museu da República. Era uma questão recorrente em diversas exposições que foram montadas no museu e que ocorria sempre que obras muito leves eram dispostas na proximidade das saídas de ar-condicionado. $\mathrm{O}$ forte vento produzido pelo sistema de refrigeração fazia balançar essas obras que deveriam ser mantidas inertes. Ressaltou também a questão desafiadora da insolação que penetrava nas salas de exibição em determinados horários do dia. Ciente da fragilidade de certos materiais que não podem ser expostos ao sol, mais uma vez lembrou que o museu foi originalmente projetado para ser uma residência de moradia de acordo com princípios higienistas em vigor no final do século XIX, motivo pelo qual o prédio foi erguido de maneira a garantir, propositalmente, que os raios de sol invadissem abundantemente seu interior. Outra particularidade do museu que exigia a atenção constante de seu departamento de design se referia as janelas do prédio, paralelas ao amplo jardim exterior. Cintia Kury explicou que quando se abriam as janelas de um lado e do outro dos ambientes internos, uma enorme circulação de ar atravessava os espaços expositivos. Também insetos se aproveitavam para se infiltrarem nesses espaços. Finalmente, a entrevistada falou da preocupação do departamento de design do museu em tentar camuflar os extintores de incêndio, para que não poluíssem visualmente as exibições.

Durante a realização da presente pesquisa, constatou-se que são poucos os museus cariocas que possuem um departamento de design permanente para questões de exibições. Cintia Kury confirmou a inexistência desse tipo de departamento no Espaço Cultural dos Correios, no Museu do Paço Imperial, no Centro Cultural do Banco do Brasil e também no Espaço Cultural da Caixa. Informou que as instituições que não contam internamente com um quadro de designers para o projeto e montagem de exposições costumam recorrer ao produtor cultural que atua aglutinando a equipe por ele sugerida, ou seja, administrando todos os profissionais envolvidos no processo relacionado a 
exibições, incluindo-se aqui as de arte. Ao se referir ao Museu de Arte do Rio (MAR), a entrevistada falou da peculiaridade da instituição de não dispor de um departamento de design, mas sim de funcionários profissionais montadores que trabalham em colaboração com os designers de exposições convidados.

\subsection{O Design de Exibição no Rio de Janeiro. O exemplo do Museu de Arte Moderna do Rio de Janeiro.}

O Museu de Arte do Rio de Janeiro (MAM-Rio), edifício localizado em terreno de $40.000 \mathrm{~m}^{2}$ a ele concedido por lei dentro do atual Parque do Flamengo no Rio de Janeiro, antigo aterro da praia de Santa Luzia, foi projetado pelo arquiteto Affonso Eduardo Reidy nos anos de 1952 a 1953 e seu paisagismo foi concebido pelo arquiteto paisagista e também artista plástico Roberto Burle Marx. O museu já existia desde 1948, ano da assinatura de sua ata inaugural, funcionando provisoriamente na sede do antigo Banco Boavista, edifício projetado por Oscar Niemeyer, localizado na Praça Pio X, no Centro da Cidade do Rio de Janeiro. Em 1952, a instituição foi transferida para o mezanino do atual Palácio Gustavo Capanema, também no Centro da Cidade ${ }^{57}$, prédio que sediava na época o Ministério da Educação e Saúde (COSTA 2013: 05).

As obras do prédio que abriga o MAM-Rio atualmente foram iniciadas em 1954, sob o governo do Presidente da República João Café Filho, mas a inauguração do chamado Bloco Escola do Museu, que contou com a presença do então Presidente da República Juscelino Kubitschek ocorreu apenas em 27 de janeiro de 1958. A construção das duas principais edificações do projeto foi terminada em 1967.

\footnotetext{
${ }^{57}$ http://mamrio.org.br/museu/apresentacao/. Acesso em 13/02/2017
} 


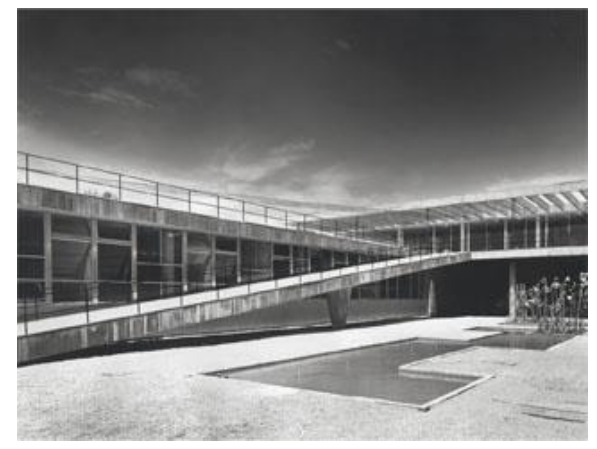

Figura 1. Foto do Bloco Escola do MAM-Rio em 1958.

http://mamrio.org.br/wp-content/uploads/2012/11/a003.jpg

Acesso em 06/09/2016

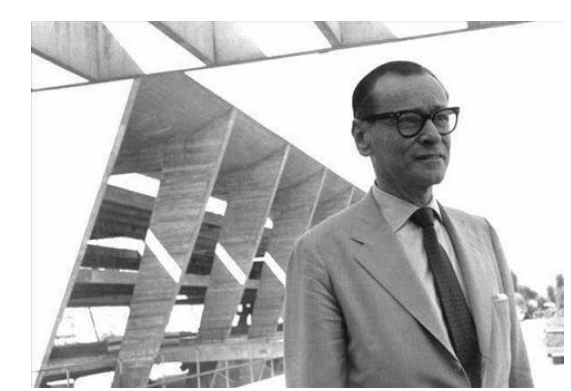

Figura 2. Reidy em frente ao MAM-Rio.

http://www.julianaburlamaqui.com.br/blog/wp-content/uploads/2012/08/image03.jpg

Acesso em 21/11/2016

O projeto foi concebido em um período pós-guerra e pós-ditadura de Vargas, época de efervescência cultural e modernização das estruturas políticas e culturais do País. As soluções encontradas, tanto do ponto de vista museológico quanto arquitetônico, se identificavam com o pensamento da vanguarda europeia da época, enfatizando a criação de espaços internos flexíveis e dinâmicos, integrados com o entorno e propícios às diversas formas contemporâneas de arte. A arquitetura estimulava a interação espacial entre oficinas, espaços expositivos e locais de encontro, enfatizando a importância da relação entre obra arquitetônica e espaço físico, buscando promover através deste a relação com os visitantes, o estímulo à criação e à reflexão artística.

Durante o período de pós-guerra, o MAM-Rio adquiriu para seu acervo algumas obras de renomados artistas europeus como Pablo Picasso, Wassily Kandinsky e Paul Klee. Nesse período também foram montadas pelo museu importantes exposições de arte abertas ao público. Sua primeira exposição, Pintura Europeia Contemporânea, foi montada em 1949 ainda na sede do Banco Boavista. Em 1953, agora Palácio Gustavo Capanema, foi apresentada a 
exposição do Grupo de Artistas Modernos Argentinos, formado por Enio Iommi, Alfredo Hlito e Miguel Ocampo, entre outros.

Em 30 de outubro de 1967 se deu a inauguração do Bloco de Exposições do museu com uma retrospectiva de Lasar Segall. Segundo Luiz Camilo Osório (OSORIO, in. COELHO, 2010: 17), ex-curador do MAM,

O salão monumental é um espaço amplo, de escala pública, que demanda obras potentes que segurem aquela escala e a força do paredão ao fundo. A grande galeria, que segue no segundo pavimento, com quase $2.000 \mathrm{~m}^{2}$, livre de colunas e janelas correndo nas duas laterais, e uma área polivalente, na qual se criam tanto espaços amplos como salas intimistas. $\mathrm{O} 3^{\circ}$ pavimento, suspenso por cima, é mais uma invenção do arquiteto e dos calculistas, mantendo-se pendurado como se fosse uma pintura na parede. A força dos materiais, a leveza das formas - as escadas são memoráveis- e acima de tudo, o diálogo aberto e livre entre o dentro e o fora, entre os prédios, a cidade, o jardim e a baía faz do MAM um dos espaços mais incríveis da cidade do Rio de Janeiro.

No memorial descritivo escrito por Affonso Eduardo Reidy em 1953, o arquiteto explicita que o prédio do MAM a ser construído não deveria perturbar a paisagem, conflitando com a natureza. Por esse motivo, o projeto conferiu predominância à horizontalidade do edifício, em contraste com as montanhas do entorno e pela estrutura vazada e transparente que se conecta com os jardins e o mar. Em lugar de confinar as obras de arte entre quatro paredes, num absoluto isolamento do mundo exterior, foi adotada uma solução aberta, em que a natureza circundante participasse do espetáculo oferecido ao visitante do Museu (REIDY, in., COELHO, 2010: 22).

Reidy prossegue:

Nos últimos 40 anos transformou-se muito o antigo conceito de museu, que deixou de ser um organismo passivo para assumir uma importante função educativa e um alto significado social, tornando acessível ao público o conhecimento e a compreensão das mais marcantes manifestações da criação artística universal e proporcionando um treinamento adequado a um contingente de artistas que, perfeitamente integrados no espírito de sua época, poderão influir decisivamente na melhoria dos padrões de qualidade da produção industrial.

$[\ldots]$

A ação eminentemente dinâmica do Museu de Arte Moderna do Rio de Janeiro, abrangendo todas as manifestações de artes visíveis dos nossos dias, requer uma estrutura arquitetural que lhe proporcione o máximo de flexibilidade na utilização dos espaços, possibilitando seja o uso de grandes áreas, seja a formação de pequenas salas, onde determinadas obras possam ser contempladas em ambiente íntimo. A galeria de exposição do MAM do Rio de Janeiro foi projetada com esse objetivo: ocupa uma área de $13 \mathrm{~m}$ de extensão por $26 \mathrm{~m}$ de largura, 
inteiramente livre de colunas, de modo a oferecer absoluta liberdade na arrumação das exposições. Essa área terá pé-direito variável: parte com 8 metros, parte com 6,40 metros e, o restante, com 3,60 metros de altura (REIDY, in., COELHO, 2010: 22,23).

Enfim, Reidy projetou um espaço arquitetural que denominou espaço fluente, inovador para os padrões da época, contrapondo-se à antiga noção do espaço confinado dentro dos limites de um compartimento cúbico (REIDY, in., COELHO, 2010: 22).

Em relação à iluminação do prédio, a opção pela iluminação natural foi a escolhida pelo arquiteto por conferir vida e movimento aos espaços, beneficiando as obras expostas da variedade de sensações que a luz diurna proporciona. Ainda, segundo Reidy, a luz, quando zenital, mostra-se difusa e uniforme, não há sombras, não há relevo, o ambiente torna-se neutro, inexpressivo. Assim, preferiu conceber o prédio sendo banhado pela luz lateral que, segundo entendia, dá direção ao espaço e relevo aos objetos, proporcionando ainda ao visitante a possibilidade de contato visual com o exterior. Finalmente, a fim de também garantir luz zenital e artificial que poderiam, dependendo da obra exposta, valorizá-la mais, o arquiteto previu que a galeria de exposição do museu, nos trechos de menor pé-direito, terá iluminação lateral e nos trechos de pé-direito duplo, iluminação zenital, através de sheds e lanternins (REIDY, in., COELHO, 2010: 23). Reidy conhecia os benefícios da iluminação artificial, sabendo-a indispensável não só para a noite, como para a exibição de objetos que possam ser prejudicados pela luz solar, como desenhos, tecidos etc (REIDY, in., COELHO, 2010: 24).

Referindo-se ainda aos tipos de luz artificial, Reidy ensina:

A qualidade da luz a ser empregada é um outro ponto de importância num museu de arte. A luz incandescente é rica em raios vermelhos e alaranjados que modificam o aspecto de certas cores. A luz fluorescente, por seu lado, provoca sensação de frieza e altera igualmente o aspecto das cores. A combinação de ambas, porém, permitirá uma grande aproximação ao efeito da luz solar. Para o MAM foi projetado um sistema muito flexível: o teto da galeria da exposição será guarnecido com placas translúcidas de um plástico vinil, as quais difundirão a luz emitida por tubos fluorescentes, proporcionando uma iluminação suave ao ambiente. A superfície luminosa assim constituída será interrompida de dois em dois metros por rasgos transversais, onde serão fixados refletores de luz incandescente, equipados com lentes apropriadas, os quais serão dirigidos exatamente para os pontos em que se fizer necessária a iluminação, sem produzirem reflexos ou ofuscamento ao visitante (REIDY, in., COELHO, 2010: 24). 
Finalmente, o memorial descritivo prevê que

Todo o segundo pavimento do corpo central do edifício será destinado a exposições, bem como uma parte do terceiro pavimentoonde ficarão ainda situados [...] o depósito para guarda das telas não expostas [...], conservadas em perfeita segurança, em condições constantes de temperatura e umidade e fixadas em traineis leves, de correr, ligeiramente afastados uns dos outros, permitindo dessa forma, reunir em um espaço reduzido um grande número de telas e assegurando-lhes perfeitas condições de ventilação e facilidade para o exame dos interessados (REIDY, in., COELHO, 2010: 24).

Fernando Coelho escreve a respeito do memorial descritivo que ele demonstra o grau de detalhamento e de zelo com que Reidy projetou o MAM. Alerta, entretanto, que o museu precisou se readaptar à passagem do tempo, o que exigiu algumas mudanças no edifício, não previstas originalmente pelo arquiteto. Dentre essas modificações, é relevante para o presente estudo comentar que alguns dos aspectos internos do Bloco de Exposições, tal como a iluminação artificial, as persianas das salas e certos detalhes originais da construção se perderam quando do incêndio ocorrido em julho de 1968. Segundo indica o autor (COELHO, 2010: 26):

Apesar de o prédio manter sua estrutura externa de forma plena após o incêndio, os novos sistemas de ar condicionado e de iluminação construídos precisaram se adaptar a outras tecnologias, intervindo minimamente no projeto original de Reidy. Além das mudanças realizadas com a reforma após o acidente, o próprio uso do espaço do museu por diferentes artistas e exposições também gerou alterações para adaptar o museu a novas necessidades expositivas e novas tecnologias. [...] Além disso, suas adaptações espaciais ao tempo e à arte contemporânea mostram que o MAM reafirma as ideias do arquiteto, já que segundo o próprio, o museu tinha como vocação, desde sua fundação, abranger todas as formas visíveis dos nossos dias.

O MAM Rio divulga em seu site que a instituição tem por fim: ${ }^{58}$

a) difundir a produção moderna e contemporânea, nacional e internacional, não só no Rio de Janeiro como em todo o Brasil e no exterior, através de exposições de sua coleção, publicações e empréstimos de obras;

b) formar, manter e preservar a coleção de obras de arte moderna e contemporânea;

\footnotetext{
${ }^{58}$ http://mamrio.org.br/museu/apresentacao/
} 
c) estimular a reflexão e o debate em torno da arte moderna e contemporânea através da organização e/ou participação em seminários, palestras, congressos e eventos;

d) organizar e disponibilizar a pesquisadores em geral a biblioteca e a documentação referente ao museu, assim como a base de dados digital de sua coleção;

e) contribuir para a formação de público por meio de atendimentos especiais a escolas, universidades e ao público em geral;

f) promover a exibição de filmes de interesse artístico e cultural;

g) desenvolver programas que disponibilizem bolsas de estudo a artistas no Brasil e no exterior;

h) explorar o seu próprio patrimônio com o objetivo de arrecadar fundos para o desenvolvimento de seus objetivos.

Durante a presente pesquisa de campo a ampla gama de informação que foi coletada por meio das entrevistas e da submissão de questionário contou também com a colaboração de Sylvia Steinberg no dia quatorze de junho de 2015 quando ela relatou parte da história e da evolução de como o Design de Exibições era praticado no Museu de Arte Moderna do Rio de Janeiro (MAM-Rio), nas décadas de 1970 e 1980, tal como ocorreu com Cintia Kury no Museu da República, espaços bem diferentes. Enfim, essas entrevistas parecerem ser a base de uma bibliografia que se constitui sobre o tema das exibições de arte que são projetadas por designers em museus brasileiros, pois ela ainda não foi encontrada até o presente momento da pesquisa.

Sylvia Steinberg, que generosamente dedicou horas de seu tempo a responder as perguntas sobre o tema Design de Exibições em museus de arte, obteve sua graduação em Design pela Escola Superior de Desenho Industrial (ESDI UERJ) no Rio de Janeiro $^{59}$ e lecionou por décadas a disciplina Desenvolvimento do projeto de programação visual na referida instituição.

Além do âmbito acadêmico, sua experiência profissional se estendeu à área de editoração, tendo contribuído para a publicação de diversos livros sobre arte. Trabalhou para a extinta Fundação Nacional de Arte (FUNARTE) no Programa Nacional de Museus, fazendo parte da equipe dedicada à elaboração do livro História Geral da Arte no Brasil, coordenado por Walter Zanini, ele próprio curador e historiador da arte.

Sylvia Steinberg possui também larga experiência na área de montagens de exposições, sejam elas de arte em sua grande maioria ou relacionadas a outros

\footnotetext{
${ }^{59}$ http://www.esdi.uerj.br/esdianos/363/silvia-steinberg
} 
temas. Inicialmente seu trabalho como designer de exibições foi desenvolvido no MAM-Rio. Posteriormente, exerceu tal atividade como profissional liberal.

Sua atuação na área de exibições de arte no Rio de Janeiro se deu de maneira ativa a partir da década de mil novecentos e setenta, trabalhando mais de dez anos como assistente de coordenação da direção do Instituto de Desenho Industrial (IDI), departamento do Museu de Arte Moderna do Rio de Janeiro (MAM-Rio) ao qual se fez alusão anteriormente. Sylvia Steinberg explicou que a cada dois ou três meses era montada uma nova exibição nos espaços da Instituição.

Durante o período acima mencionado, vigorava entre o MAM-Rio e a ESDI uma parceria. Tratava-se de uma cessão de trabalho de professores da Escola Superior de Desenho Industrial para o Instituto de Desenho Industrial do museu, existente de 1968 a 1978. Lembra-se que à época, o MAM-Rio não possuía um departamento específico de design tal como nos dias atuais. Sylvia Steinberg estimou que o Instituto de Desenho Industrial (IDI), atuando em parceria com a ESDI, era responsável pela montagem de $99 \%$ das exposições realizadas à época no MAM-Rio. Ao Instituto cabia também desenvolver pesquisas sobre assuntos de interesse do museu.

Sylvia Steinberg relatou que acompanhou de perto a experiência de montagem das primeiras exposições de diversos artistas brasileiros contemporâneos que naquela época tinham idade em torno dos vinte anos. É de conhecimento geral que o MAM-Rio acolhia desde a década de 1950 a arte brasileira experimental, de vanguarda. O edifício abrigou, dentre outros, o Grupo Frente (1954), o Neoconcretismo (1959), A Nova Objetividade Brasileira (1967), as mostras Opinião 65 (1965), Opinião 66 (1966) e o Salão da Bússola em 1969 (COSTA, 2013: 05).

Ao comparar a maneira como exercia sua atividade com a maneira pela qual a mesma é exercida atualmente, pareceu à entrevistada que quem hoje lida com montagem de exposição de arte tem uma energia incomum porque as demandas, as obrigações e as imposições, num ritmo nunca natural, podem se mostrar estressantes, de acordo como que tem ouvido em relato de colegas.

Sylvia Steinberg pontuou que essa talvez seja uma grande diferença em comparação ao tempo em que trabalhou no MAM-Rio. Explicou que trabalhava de uma hora da tarde às sete horas da noite, e que não se lembrava de ter passado 
noites trabalhando, não se lembrava de ter trabalhado hora extra, a não ser quando se programava que determinada montagem deveria ser realizada no final de semana por um motivo estratégico, ou no caso de exposições itinerantes. Segundo ela, a atual tendência dos designers de exibições de trabalharem sem parar, sem ter tempo de reflexão, não era uma realidade nas décadas de 1970 e 1980. Prosseguiu afirmando que hoje existe o pressuposto de que o profissional designer tem que estar disponível e responder a demandas dentro de um prazo supostamente adequado, sob pena de não ter inserção ou não se manter no mercado. Sylvia Steinberg associou essa mudança de perfil à influência do marketing, negativa por reforçar um sistema que transforma tudo em objeto comercializável.

Prosseguindo na entrevista, Sylvia Steinberg explicou que a elaboração das exibições de arte no MAM-Rio naquela época assumia perfis distintos de acordo com a fonte do projeto. Assim, a montagem da exibição apresentava variações conforme fosse determinada por parte de um consulado, hipótese em que o projeto da exposição e de sua montagem já chegava pré-estipulado ao museu, ou por parte da vanguarda artística da época, caso em que normalmente o próprio artista determinava como seria o projeto expográfico das obras que haviam sido selecionadas para sua exposição. No caso de bienais de arte, o tratamento era ainda mais específico - nesse caso, desde a concepção, passando pela montagem, até o material de divulgação, tudo era feito pelo designer.

Entretanto, Sylvia Steinberg ponderou que lhe parece que atualmente não vigora mais a realidade acima descrita. A tarefa de conceber exposições de arte que nas décadas de 1970 e 1980 eram majoritariamente exercidas por artistas e por designers, passou a contar quase que obrigatoriamente com a figura do curador a partir da década de 1990. Atualmente e em linha de continuidade com tal mudança ocorrida desde o final do século XX, as exposições são de caráter temático, ou retrospectivo, podem reunir algo de coleções particulares ou um material específico de uma única coleção, e o olhar disso depende da inteligência do curador. Caberá ao designer de exibições materializar essa visão.

A entrevistada referiu-se ao crítico de arte Roberto Pontual para relembrar suas palavras a respeito da inexistência de uma curadoria imparcial. Atualmente, o mais importante ao designer de exibições, segundo Sylvia Steinberg, seria entender, a partir do olhar particular do curador, quais são as possibilidades de que 
dispõe para enfatizar o material a ser exposto e saber como e quando intervir já que sua intervenção pode até mesmo inviabilizar o que se pretende transmitir.

Sylvia Steinberg relembrou que no Brasil houve uma mudança na atuação do designer de exibições que se radicalizou entre as décadas de 1980 e 1990 . O designer passou a ser alguém disposto a ouvir e a entender o que se pretendia sobre a exibição, trabalhando a várias mãos, diferentemente de como atuava anteriormente, durante as décadas de 1970 e inicio de 1980. Neste período, segundo Sylvia Steinberg, havia no Brasil um caminho a ser seguido, um foco, um excesso de certezas. A não ser pela ruptura promovida pelos artistas experimentais brasileiros e por certas experiências internacionais por vezes assimiladas em nosso país, sempre se buscava o que era tradicionalmente considerado bom, certo. Nossa entrevistada, em contrapartida, citou o exemplo do que já se fazia desde a década de 1940 no Centro George Pompidou, em Paris. Relatou que nas exibições sediadas pelo museu de arte contemporânea francês, muitos profissionais, designers ou não, ofereciam seus diversos pontos de vista sobre uma mesma questão, realizando um trabalho em conjunto seja na elaboração, na montagem ou na editoração de catálogos das exibições.

Aqui se faz um adendo à entrevista para se citar o exemplo do Museu do Louvre em Paris. No documentário La Ville Louvre ${ }^{60}$, filmado após renovação realizada no mencionado museu na década de 1980 e que acrescentou a famosa pirâmide de vidro ao prédio, diversas categorias profissionais atuam em separado ou em conjunto a fim de montar as salas de exibições com seus quadros, esculturas, relógios antigos. Elencam-se, a título apenas exemplificativo, as figuras do curador, dos transportadores dos objetos do acervo museal, dos restauradores, dos relojoeiros, dos monitores de sala, dos seguranças. Trata-se de um objetivo compartilhado por muitos e, portanto, atingido graças ao trabalho em equipe.

Retornando-se à entrevista, Sylvia Steinberg percebeu, portanto, diversas mudanças que foram ocorrendo na sua área profissional ao longo de quarenta anos de trabalho. Relatou que durante as décadas de 1980 e 1990 se verificou no Brasil uma transformação importante, de forte influência europeia, relacionada à preocupação com a ambientação, com a cenografia, com a necessidade de se

\footnotetext{
${ }^{60}$ La Ville Louvre, 1990, diretor Nicolas Philibert.
} 
apresentar uma narrativa para o material exposto. A mera apresentação dos objetos deixou de ser o único elemento essencial de uma exibição. Essa informação trazida por Sylvia Steinberg se coaduna com o que já se escreveu no capítulo anterior sobre o trabalho desenvolvido por Gisela Magalhães nas exibições do Museu da República no Rio de Janeiro ou em outros estados brasileiros.

Sylvia Steinberg defende, quanto à tendência cenográfica das exibições de arte, que os avanços do ponto de vista formal têm seu valor, mas que a maneira minimalista de se exibir obras de arte, tão usada no passado recente, não deveria ser desconsiderada nos dias atuais. Citou o Instituto Moreira Salles no Rio de Janeiro e o Instituto Tomie Ohtake em São Paulo como exemplo de espaços expositivos no Brasil que abraçam a ideia minimalista que não recorre a subterfúgios ou espetáculos para difundir o conteúdo que se intenta propagar.

Outra questão abordada durante a entrevista foi a da divulgação, registro e conhecimento das exposições. Sylvia Steinberg explicou tratar-se de questões que sempre foram importantes, mas ponderou que na atualidade a educação pela arte ganha cada vez mais significado e relevância. Lembrou que na década de 1980 já se trazia para o Brasil a experiência londrina da arte e educação que, por exemplo, percebia a criança como um ser dotado de inteligência. Assim, as montagens de exibições de arte deveriam considerar as diferenças existentes entre crianças, adolescentes e universitários que começam a frequentar o espaço expositivo. Hoje essa experiência de arte e educação é realizada no Rio de Janeiro pelo Museu de Arte do Rio (MAR) e pelo Centro Cultural do Bando do Brasil, segundo a entrevistada. Tem-se conhecimento que também o Instituto Moreira Salles possui um departamento educativo ativo.

Para Ana Luísa Nobre, conforme relato colhido em entrevista, a função de coordenadora dos projetos educativos das exposições do Instituto Moreira Salles (IMS) que desenvolve no referido centro cultural a coloca constantemente em estreita relação com o público visitante. A professora acrescentou que o desenvolvimento do setor educativo dos museus vem ganhando cada vez mais relevo no mundo todo. O Brasil também vem adotando esforços nesse sentido, porém entende que a área ainda se mostra por aqui em uma fase bastante inicial se comparada ao estágio já alcançado pelos grandes museus do mundo. Ressalvou, 
entretanto, a importância da tomada de conscientização nacional de que o país precisa crescer nesse setor, ainda que as dificuldades sejam muitas.

Ainda segundo Ana Luísa Nobre, em um cenário ideal, há que se inserir a curadoria relativa ao projeto educativo de uma exposição desde a fase de conceituação do seu projeto expográfico. Ela ensina que o projeto educativo tem várias linhas de ação para públicos distintos, desde o infantil até o adulto, especializado ou não, e que envolve uma mediação, que pode e merece ser provocada pela instituição em questão, ao invés de apenas aguardar sua solicitação por parte dos visitantes das exposições. Como, porém, se pode ativar essa relação? Segundo a entrevistada, a relação das instituições museais ou culturais com a universidade é potencialmente muito rica, e a aproximação pode se efetivar por meio de workshops, seminários, cursos, atividades, de maneira que a exposição seja o disparador de uma pesquisa, de uma reflexão que possa ser desenvolvida posteriormente na universidade, de uma maneira diversa.

Nesse sentido, Ana Luísa Nobre falou sobre o contato que se desenvolveu entre a PUC-Rio e o Instituto Moreira Salles no período de elaboração da exposição O Momento Presente, do artista albanês Anri Sala. Explicou que em 2015 houve um workshop na universidade que contou com a presença do artista. Quando sua exposição foi inaugurada em setembro de 2016 no mencionado instituto, o artista, pouco conhecido dos brasileiros, já havia criado um público cativo por conta das atividades realizadas na universidade carioca. Essas pessoas foram visitar sua mostra e viram a arte exibida já previamente informados da proposta do artista. Para Anri Sala, o contato prévio com os estudantes e demais frequentadores da PUC-Rio também lhe proporcionou uma troca de ideias úteis para a concepção da exposição.

Ana Luísa Nobre lembrou ainda do material informativo prévio à exibição que envolve publicações, sites, blogs. A entrevistada afirmou que existe uma faísca que a exposição pode provocar posteriormente ao seu término e acredita que o design pode contribuir para tanto.

De volta à questão da montagem de exibições, Sylvia Steinberg mencionou, no transcorrer da entrevista, a preocupação atual do designer relativa à interação com o espaço físico que abriga a exposição. Ela disse que, ao longo de sua carreira como designer de exibições, pôde perceber uma crescente consciência de se respeitar esse espaço. Explicou que hoje se evita cortar portas pelo meio, 
encaixotar as pessoas, radicalizar com rebaixamento de tetos, salvo se realmente necessário. Como exemplos da interação inteligente com o espaço, Sylvia Steinberg citou algumas exposições ocorridas na Casa França-Brasil durante a gestão de Pablo de La Barra, dentre elas a de Iole de Freitas aberta à visitação de outubro de 2009 a fevereiro de 2010 e a de Ivens Machado aberta à visitação de dezembro de 2011 a fevereiro de 2012. Segundo Sylvia Steinberg, essas duas exibições montadas em um lindo espaço levaram o visitante a contemplar as obras como nunca se fez antes no Rio de Janeiro.

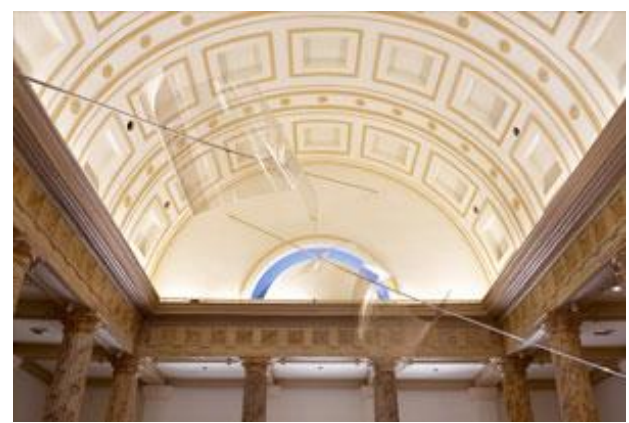

Figura 3. Exposição Iole de Freitas. http://www.casafrancabrasil.rj.gov.br/wpcontent/uploads/2014/10/IoledeFreitas.jpg

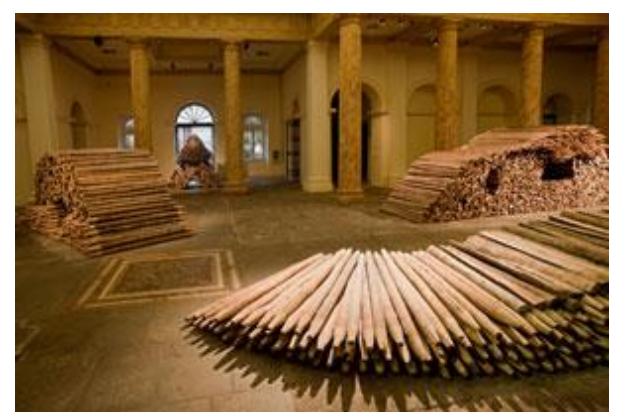

Figura 4. Exposição Ivens Machado.

http://www.casafrancabrasil.rj.gov.br/wpcontent/uploads/2014/10/IvensMachado.jpg

O mesmo apreço Sylvia Steinberg demonstrou pela Galeria Lygia Pape, projeto de Maria Paz e Thomas Regatos em Inhotim, centro que abriga a coleção de arte contemporânea do empresário Bernardo Paz em seus pavilhões e no extenso parque arborizado que integra a propriedade localizada no vilarejo de Inhotim, próximo à área urbana de Brumadinho, a 60km de Belo Horizonte, 
Minas Gerais (SERAPIAO. 2011: 15, 36). Sylvia Steinberg elogiou a galeria mencionada pela originalidade da montagem da exposição, pelo respeito ao espaço que é assimilado e ocupado de acordo com a sua natureza, por integrar o espaço à obra da artista ou até mesmo expandi-la, apresentando-a de maneira desmembrada em diversos espaços diferentes.

A entrevistada concluiu que quando a exposição tem a inteligência da curadoria associada à inteligência da montagem, o público se emociona ao ponto de buscar informação, tarefa esta que se torna mais acessível a todos se a ideia da concepção e da montagem da exposição tiver sido divulgada por meio de livros ou no ambiente virtual. Citou Luis Pérez-Oramas, curador da trigésima bienal de São Paulo, que inovou duplamente em seu projeto, tanto ao deixar o prédio da bienal desnudo a ponto de possibilitar a intercomunicação entre vários espaços como ao disponibilizar material didático sofisticado sobre a concepção do evento, permitindo o acesso prévio a esse material, quase como um preparo para quem iria ver a exposição, divulgando ainda em pequenos textos as matrizes de pensamento que informaram sua curadoria.

Sylvia Steinberg considerou também que o material de registro de exposições deve estar impregnado não apenas da obra pura e simples, mas da obra contextualizada no próprio espaço expositivo e, no caso de exposições itinerantes, em outros espaços já percorridos, trazendo ampla gama de informações sobre o que foi o evento. Deve conter ainda informação sobre o artista, seus trabalhos do passado e recentes. Isso permite uma pesquisa posterior na internet. Nossa entrevistada acredita que esse material de documentação do evento é de grande importância para quem vai trabalhar na área no futuro.

Em referência à distribuição dos objetos expostos em museus, Sylvia Steinberg entende tratar-se de um fazer bastante formal, com um direcionamento que tantas vezes escapa ao visitante comum. Ensina que hoje quase não se fala mais em organização das obras dentro do espaço, mas sim em dispositivos expositivos que permitem um diálogo e uma fruição de conteúdo que são ou não nucleados, lineares, de ruptura, enfim, são de variadas naturezas. Ressalvou que atualmente a sequência linear é pouco utilizada.

Quanto ao material de divulgação, ela explicou que ele será tão mais inteligente quanto for a curadoria da exposição. O designer que tenha experiência tanto na área de montagem de exibições quanto em editoração poderá contribuir 
de maneira substantiva para construir um diálogo entre o exposto e o que será registrado e divulgado.

O designer, profissional treinado para oferecer um olhar formalista e técnico, segundo a entrevistada, aos poucos percebeu que deveria se envolver também com aspectos outros que os técnico-formais. Ele aprendeu que é preciso pensar seus projetos considerando as variáveis do sentimento, do fazer social e político, das questões internacionais que estão em pauta. Uma exposição muito bem montada possibilita ao visitante saber quem é o artista, quem é o curador. Segundo a entrevistada, se o designer entender o que é essa perspectiva de inserção da arte hoje, ele vai cada vez mais se sensibilizar pelo espaço, pelo conteúdo que se expõe e pela interlocução com o curador, com o divulgador, com quem trabalha com arte educação, e pela maneira como ele se comunica.

Perguntada sobre quais categorias profissionais trabalham em conjunto com o designer de exposições, Sylvia Steinberg ponderou a dificuldade de nomear todas elas porque certamente o elenco dependerá da natureza da exposição. Sylvia Steinberg então ofereceu como exemplos a curadoria, os profissionais de iluminação, os profissionais que trabalham os elementos virtuais do campo expositivo e lembrou-se da atual necessidade da presença do cenógrafo para questões de ambientação das exposições e da interatividade do expectador. Considerou que a interatividade promovida atualmente é algo que mudou de patamar se comparada com o que se fazia nas décadas de mil novecentos e setenta e oitenta. Exposições de Ligia Clark ou de Hélio Oiticica já eram interativas, mas por outros motivos que não os de hoje. A busca pela interatividade já existia, porém ela avançou para possibilitar que hoje seja tanto física como virtual, uma não eliminando a outra. Exemplificou ainda os profissionais da área de preparação e revisão de texto, de documentação ou da área de som, tal como sonoplastas ou narradores, locutores.

Referiu-se, finalmente, a outro profissional que existe hoje em dia e que não existia quando a entrevistada começou seu trabalho na área de exibições de arte: o produtor cultural. Sua função é substantiva na sua opinião. Ou ele é culto, inteligente e atento, ou vai montar um desastre porque nos dias atuais o designer não faz nenhuma demanda direta, ele se vale do produtor para produzir o que ele projetou, para avaliar os custos daquela produção, para familiarizá-lo com 
determinadas escolhas apontadas no briefing que possam fugir à sua experiência prévia.

O produtor cultural é um profissional vital, lida com algo que os designers não estavam habituados. Ele que faz o contato, o diálogo entre o espaço expositivo e o design. Antigamente cabia ao designer contatar o curador, o diretor do museu e outros envolvidos na exibição. Hoje não mais. Certamente vai existir um produtor para realizar tais intermediações. Trata-se de tarefa complexa, há que ser pessoa com formação muito sólida. Se for um aprendiz de feiticeiro que reúne coisas para colocar no lugar, sem pensar, o designer estará em apuros.

Finalmente questionou-se se o projeto de design de uma exposição de arte contemporânea varia muito em relação à elaboração de uma exposição de arte tradicional e em que aspectos. Sylvia Steinberg acredita que sim, que em exposições de arte contemporânea, principalmente se os artistas envolvidos estiverem vivos e ativos, a possibilidade de mudanças e alterações contínuas é sempre muito maior do que no caso de exposições de arte não contemporânea. Com isso não se quer fazer crer que esta exposição de arte não possa ser interativa e atual na sua montagem. Montar uma exposição de arte barroca não significa montá-la barrocamente, como explicou, mas ela terá provavelmente um perfil mais calmo e menos mutante do que uma exposição de arte contemporânea. Sua percepção foi corroborada por Carla Marins, atual designer chefe do departamento de design do MAM-Rio, conforme se transcreve logo a seguir e também no subcapítulo seguinte.

Sylvia Steinberg pensa que nunca se viu, como nos dias de hoje, um processo de mutação de exposições de arte tão intenso como o que se pode verificar em algumas exposições contemporâneas que são capazes de se transformar praticamente todo dia com performances, intervenções, com a presença dos artistas, com workshops. A exposição de arte contemporânea geralmente traz em si a necessidade de causar impacto.

A título de ilustração, cita-se a exposição Humúsica ocorrida no MAM-Rio em outubro de 2012 do artista, compositor, rapper e poeta Cabelo. Segundo Carla Marins, a cada dia a exibição se transformava. Um dia acendia-se fogo, outro dia ocorria uma apresentação ao vivo de dança do passinho ou ainda, o artista colocava terra com planta e minhoca no meio do espaço expositivo. Ouvia-se também música funk. Como definiu Luiz Camilo Osorio, o curador da mostra: 
Humúsica é uma exposição sobre tudo: desenho, performance, poesia, escultura, música. É uma exposição-instalação do Cabelo. E também do MC Minhoca e do DJ Esterco. Não há que se ater aos detalhes. Tudo é húmus (e música). Uma coisa se transforma e se fertiliza na outra. Metamorfose e ruído. Contaminações que fazem um elemento residual se tornar possibilidade plástica. O processo de criação acontece a cada ativação da obra. Nada vem para o espaço expositivo já feito, mas se deixa instalar poética e plasticamente pelas novas relações constituídas em ato (..... ${ }^{61}$

Segundo o artista contemporâneo Philippe Parreno:

Uma exposição é um formato, um quadro com vocação experimental, pode-se colocar de tudo ali dentro: um workshop, uma manifestação, uma videoconferência, uma situação, um teatro de sombra, um espetáculo de música hall, um filme, uma estrutura de pensamento, um espaço de proximidade, uma festa promocional (PARRENO. Alien Affection, 2002, apud. BURLURAUX \& SCHERF \& SEIDEL, 2009: 27).

\subsection{O exemplo do Museu de Arte Moderna do Rio de Janeiro nos dias atuais.}

Entrevista conjunta foi realizada em junho de 2015 com Carla Marins, designer e chefe do departamento de Design do Museu de Arte Moderna do Rio de Janeiro desde 1998 e Rafael Rodrigues, designer e seu assistente desde 2010.

Carla Marins explicou que seu trabalho tem como foco principal a montagem das exposições. Porém explica que no MAM-Rio todos fazem de tudo porque o museu é um organismo grande, é amplo, com diversos setores e a parte de design abrange desde a papelaria até a sinalização, passando pela programação visual, peças gráficas e a montagem da exposição.

Sobre a sua experiência profissional no MAM-Rio, Carla Marins afirmou, como primeiro ponto a ser abordado, que o papel do designer na montagem de uma exposição de artes plásticas está diretamente ligado ao seu envolvimento com o curador dessa exposição, com o que este último deseja sobre a exposição. E $o$ curador é como se fosse o pai da exposição, ele que a pensou, que a gestou antes da sua montagem. Os designers não participam dessa gestação. Ela chega aqui

61 http://www.premiopipa.com/2012/11/cabelo-e-bonde-do-passinho-no-mam-rio/. Acesso em 03/12/2016 
pronta. Carla prosseguiu explicando que os curadores são muito díspares, cada um tem a sua linha de atuação.

Carla Marins informou que o MAM-Rio contava com Luis Camilo Osório como curador de artes plásticas, mas que o museu também trabalhava com outros curadores convidados por ele. Toda a curadoria de artes plásticas estava, portanto, centrada na pessoa dele, exceto quando a própria presidência do museu trazia exposições por seu próprio empenho pessoal, tal como foi o caso da exibição das obras de Louise Bourgeois. Explicou que geralmente essas exposições são caríssimas, pois os valores do seguro das obras são astronômicos. Como o apelo ao público deve ser muito grande por conta dos gastos realizados, essas exposições são particularmente difíceis de serem trazidas e envolvem o empenho direto da direção do museu. Fica claro também que tais exposições também são realizadas em conjunto com o curador, que nunca é algo que o curador não deseje receber, mas o todo é realizado com o empenho direto da direção.

A equipe de design do MAM participava da montagem de algumas exposições nos salões do museu em junho de 2015. Carla Marins falou em especial sobre duas delas no decorrer de nossa entrevista. A primeira, chamada Temporama, com trabalhos realizados entre 1985 e 1991 pela artista francesa Dominique Gonzalez-Foerster, que foram reconstituídos pela primeira vez para essa exibição $^{62}$ e com curadoria do mexicano Pablo Léon de la Barra, anterior diretor da Casa França-Brasil, ocupou uma área de $1.800 \mathrm{~m}^{2}$ no segundo andar da instituição, entre os dias vinte de junho a nove de agosto. A segunda, chamada "Marginália 1", apresentou a retrospectiva da obra do artista gráfico, músico, compositor e poeta Rogério Duarte. A exposição teve a curadoria de Manuel Raeder e do próprio artista, com a colaboração de seu filho Diogo Duarte e ficou aberta para visitação entre vinte de junho e dezesseis de agosto de $2015 .^{63}$

Referindo-se a exibição da artista Dominique Gonzalez-Foerster, nossa entrevistada explicou que após a escolha feita pelo curador de abrigar os trabalhos no salão 2.4 do museu, coube aos designers fornecer as caraterísticas técnicas que

\footnotetext{
${ }^{62} \mathrm{http} / / /$ oglobo.globo.com/cultura/artes-visuais/dominique-gonzalez-foerster-banha-mam-decores-anuncia-preciso-reinventar-futuro-16522321. Acesso em 18/11/2016.

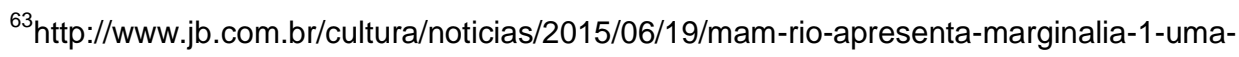
retrospectiva-da-obra-de-rogerio-duarte/ Acesso em 18/11/2016
} 
o espaço possuía, tal como a metragem do salão, a sua luz, suas características, seu piso e o seu mobiliário. A artista teve liberdade total de fazer o que queria e optou por receber o espaço de $1800 \mathrm{~m}^{2}$ do salão livre, vazio, rejeitando o mobiliário. Segundo Carla Marins, o papel dos designers do museu nesse trabalho seria de pouca monta, já que a própria artista francesa havia se ocupado da arrumação do espaço. Assim, não haveria nada a fazer além de fornecer o salão. Entretanto, lembrou a questão de design que essa opção da artista pelo espaço vazio causou porque nesse espaço há painéis que não podem sair do museu. Informou que esse mobiliário/material só sai do museu quando o prédio é ocupado por reuniões de chefes de Estado. Nesse caso, uma transportadora envia caminhões ao MAM-Rio e há o desmonte desses painéis em duzentas peças que são levadas para depósitos e posteriormente são novamente remontados ao retornarem ao museu, enfim, uma operação quase de guerra e custosa nas palavras de Carla Marins. Esses painéis foram feitos para ficarem dentro do museu, andam pelo andar inteiro, se conectam e formam arquiteturas. Finalmente, a entrevistada afirmou que a pessoa que caminha dentro do museu passa pela arquitetura criada pelos painéis e pode nem se dar conta que aquilo foi projetado para aquela exposição. Pode achar que o painel sempre esteve ali, mas não, cada exposição tem o seu projeto.

Mostrou-se urgente resolver a questão de onde se alocar os painéis projetados por Bergmiller, a fim de se esvaziar o salão 2.4 do museu. O departamento de design conseguiu distribuir parte dos painéis nos outros três salões disponíveis. Entretanto, ainda havia sobrado setenta e cinco painéis no espaço destinado a exibição da artista francesa que precisavam ser escondidos. A solução espacial encontrada pela equipe de design foi a seguinte: na parte de trás do referido salão há equipamentos como elevador cargueiro e sua enorme porta, caixa de incêndio, quadro de luz, elementos que "sujam” o salão. Carla Marins informou que foi erguida uma parede na frente disso tudo e atrás dela foi possível dispor um terço dos painéis restantes.

Ainda em relação à exibição, a designer informou que a artista inicialmente planejava montar seu trabalho que simula uma piscina no vão do salão, distribuindo seus outros trabalhos no espaço que se seguiria. Carla Marins relembrou que Reidy havia projetado arquitetonicamente esse espaço de forma a colocar o vão do salão 2.4 equidistante, isso porque o salão é perfeito. Então há 
equidistância tanto na largura quanto no cumprimento. Quando a artista recebeu a planta, viu que o vão era o centro do salão e instalou aí sua "piscina". A entrevistada explicou que se a equipe de design tivesse camuflado todos os setenta e cinco painéis atrás de uma única parede, erguida em uma única área do dito salão, a distância entre o início da exposição e a "piscina" e o final da exposição e a "piscina" seria desigual, contrariando o projeto de Reidy. Por esse motivo, a equipe mesclou o espaço, diminuindo a entrada e a saída, para permanecer de certa forma equidistante, pelo menos visualmente, ainda que não matematicamente. Ainda, foi montado um corredor como entrada da exibição onde se podia ver uma imagem da artista caracterizada de Fitzcarraldo, a personagem do filme de mesmo nome dirigido por Werner Herzog em 1982. De cada lado desse corredor, sem que o visitante percebesse, havia uma sala à esquerda e outra à direita, locais em que se camuflou o restante dos painéis.

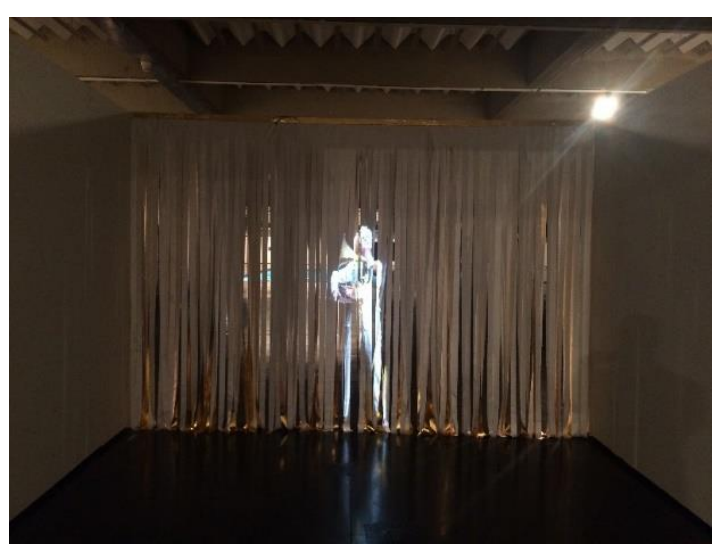

Figura 5. Corredor da exposição Temporama.

http://centrefortheaestheticrevolution.blogspot.com.br/2015/12/temporamadominique-gonzalez-foerster.html. Acesso em 22/11/2016. ${ }^{64}$

\footnotetext{
${ }^{64}$ Pode-se perceber na imagem o corredor criado pela equipe de design para conduzir os visitantes à exibição e, ao mesmo tempo, esconder por trás das paredes laterais os painéis móveis do museu.
} 


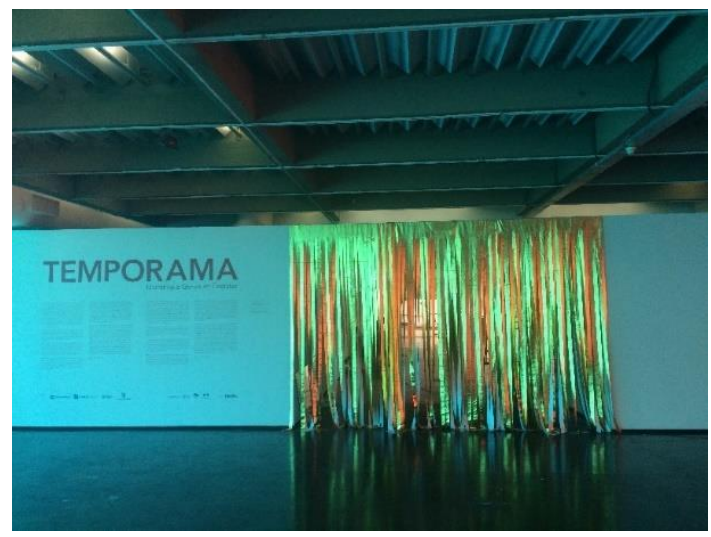

Figura 5.1 Entrada da exposição Temporama.

http://centrefortheaestheticrevolution.blogspot.com.br/2015/12/temporamadominique-gonzalez-foerster.html. Acesso em 22/11/2016. ${ }^{65}$

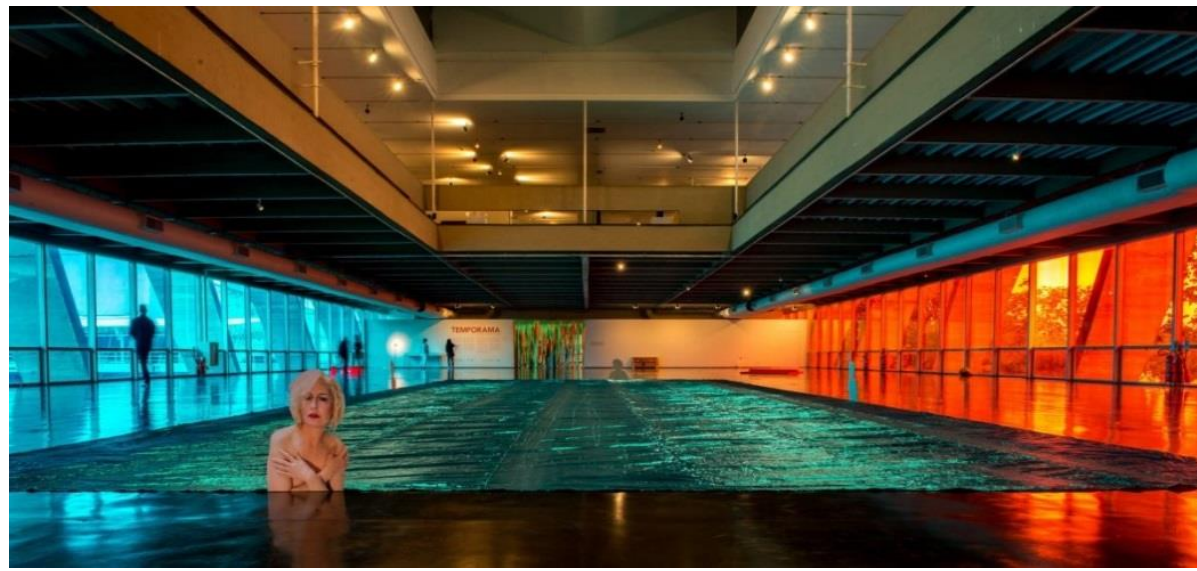

Figura 5.2 "Piscina" da exposição Temporama.

http://radardecoracao.com.br/wp-content/gallery/temporama/2pj_0367-mamdominique-gonzales-foerster.jpg. Acesso em 22/11/2016. ${ }^{66}$

${ }^{65}$ Imagem da entrada da exibição, após percorrido o já referido corredor, com as salas laterais usadas como local de depósito camuflado dos painéis móveis.

${ }^{66}$ Observa-se nessa imagem a "Piscina" localizada no vão do salão 2.4 do MAM-Rio e como o espaço da mostra foi esvaziado de painéis e de outros suportes expositivos. 


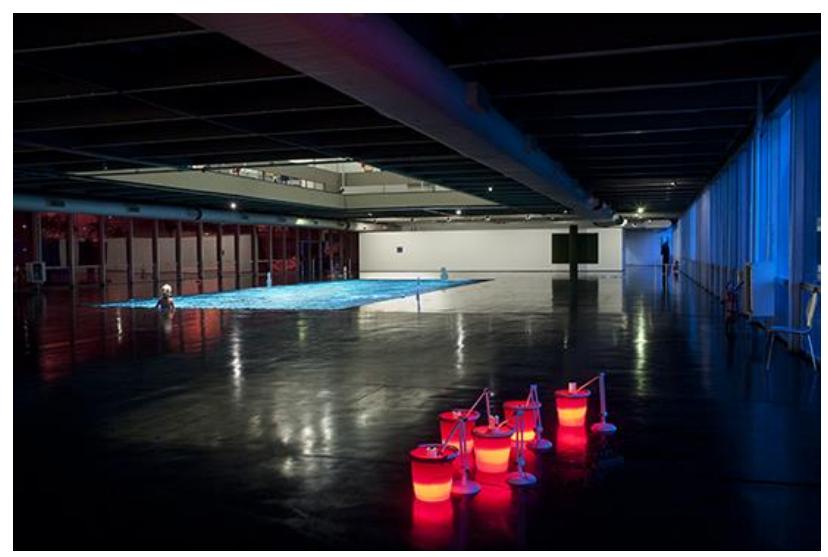

Figura 5.3 Equidistância do salão 2.4.

http://www.estherschipper.com/sites/default/files/ES_EXHIBITIONS/2015_D

GF/DGF_MAM\%20RIO\%2C\%202015_21\%40.jpg. Acesso em 22/11/2016.

Como resumiu Carla Marins, ao se entrar no salão 2.4., o trabalho feito pelos designers nesse espaço foi para não ser visto. Clarificou que esse detalhe técnico não ocorre sempre no planejamento de exibições de arte.

Há designer que quer ser visto. Aqui nós queremos que o artista seja visto, saber se posicionar neutro ou não visto é muito difícil, a predominância deveria ter sido e foi a do trabalho da artista. Geralmente o departamento de Design do MAM busca oferecer um projeto no qual o bom design fica invisível.

A entrevistada ponderou, entretanto, que em muitas exposições que já visitou em diversas instituições, o projeto cenográfico é praticamente a própria exposição. Frisou que não se posiciona contrariamente a esse tipo de arranjo espacial quando cabível e citou a exposição Instalação Grande sertão: veredas, aberta ao público de agosto a setembro de 2007 no MAM-Rio.O projeto expográfico foi realizado pela atriz, diretora de teatro e cenógrafa Bia Lessa e o tema da mostra não era sobre artes plásticas, mas sobre o consagrado livro de Guimarães Rosa e assim tratava das palavras, da literatura. Carla Marins considerou magistral o trabalho de Bia Lessa que se serviu de muitos recursos e fez um uso muito diferente do museu, expondo objetos e textos até mesmo dentro da saída de emergência ou nos depósitos de mobiliários que são áreas escondidas. Ela incorporou essas áreas à exposição, pintou de dourado e colocou música de Maria Betânia para o público sentar em banco e ouvir.

Carla Marins reafirmou ser muito bom trabalhar com designers convidados, eles oferecem ao público algo novo e para o departamento de design do MAM- 
Rio a oportunidade de aprender uma visão nova. Porém a entrevistada não acredita que esse tipo de projeto funcionaria em uma exibição de artes. Informou acreditar que os artistas plásticos, em $99 \%$ dos casos, recusariam qualquer montagem que achassem que competisse com eles, com a obra deles.

Perguntados sobre qual o papel do designer nesse processo de elaboração e montagem de exibições de arte, Carla Marins respondeu que várias categorias profissionais trabalham juntas na elaboração da exposição. Segundo ela, cabe ao designer colocar os objetos em evidência, transmitindo a vontade desejada pelo curador. Prosseguiu afirmando que o curador imagina uma exposição, mas não sabe como ela vai se comportar. Ele cria uma ideia abstrata e as equipes dão forma a ela, ao material educativo, à mídia eletrônica. Por isso, conforme Carla Marins,

se o curador pode ser considerado como o pai da exposição, o designer poderia ser chamado de a mãe da exposição, pois ele deu forma, ele "pariu" materialmente aquele conceito que se transformou em números, medidas, materiais, dinheiro gasto, enfim, que transformou aquilo em visibilidade, transformou a ideia em algo palpável.

Carla Marins explicou que no MAM-Rio o processo de trabalho dos designers é feito segundo dois pilares fundamentais. Primeiramente, os designers precisam ter conhecimento do material que será exposto, do artista e o que ele trabalha, em que ponto está seu relacionamento com o mundo hoje, ou seja, quem é essa pessoa e a relação dele com a contemporaneidade. O outro pilar é o profundo conhecimento do espaço expositivo e do que ele pode oferecer. No caso do MAM, há ainda a necessidade do conhecimento de seu mobiliário expositivo. Em resumo, os designers devem equilibrar os dois fatores - o fator conceitual do desejo do curador, quem é o artista e qual a sua linguagem e o espaço em que irão expor. Segundo Rafael Rodrigues, as exposições coletivas são as mais difíceis de serem realizadas, pois não se pode sobressaltar um artista em relação a outro.

No tocante a relação de trabalho do curador com o designer de exibições, menção foi feita a exposição do artista Amílcar de Castro, com curadoria de Paulo Sergio Duarte, professor que dá aulas de História e Crítica de Arte, que esteve em cartaz no MAM-Rio até oito de fevereiro de 2015. Carla Marins relatou que apesar do museu já contar com seu próprio mobiliário, outro foi construído especificamente para essa exibição, a pedido do curador. A disposição dos objetos 
tridimensionais e dos desenhos do artista expostos não foi cronológica por decisão do curador que queria algo claramente compreensível. Assim, os designers decidiram pelo grupamento por material, proposição que foi prontamente acatada pelo curador naquele caso. Nossa entrevistada explicou, portanto, que o designer oferece o máximo de possibilidades para o que possa acontecer, mas também deve opinar, fazer ver ao curador certas particularidades do espaço. Porém, nem sempre as opiniões dos designers são acatadas.

Carla Marins citou o fato de que há curadores que não os escutam, dificultam, por vezes, a visão dos visitantes, fazem unicamente o que desejam, podendo até mesmo brigar por conta da presença de um extintor de incêndio, por exemplo. Tanto Carla Marins como Rafael Rodrigues consideram, conforme disseram, que isso é a vida da gente. Elucidaram que o designer, que visualiza melhor o espaço por trabalhar mais com isso, já sabe que um determinado tipo de disposição vai incomodar o visitante, mas o curador, por vezes, quer que a ideia dele seja a que prevaleça. Segundo Carla, por uma questão de hierarquia, é a vontade do curador que prevalece.

Foi perguntado se isso acontecia com frequência no MAM-Rio, ao que os entrevistados disseram que isso ocorria em todos os lugares. Carla Marins relatou que na maioria das vezes em que montou exposições fora do MAM-Rio houve uma cumplicidade grande com os curadores e que eles acataram todos os conceitos. Mas eventualmente no MAM-Rio ela observou que muitos curadores chegam com próprias ideias prontas e eles precisam aprender na prática que algumas dessas ideias não funcionam com o edifício que Reidy projetou. Carla Marins foi enfática na sua consideração de que o prédio que abriga o MAM-Rio é completamente perfeito, que havia sido projetado e construído para receber exposições e que faz isso com maestria. É um edifício perfeito para isso, mas alguns curadores não entendem isso no primeiro momento e criam ideias que não vão ser bem-sucedidas. Como explicou nossa entrevistada, no MAM, alguns curadores precisam aprender vendo que aquilo não funciona. Do contrário, terão que desfazer, ao final, aquilo que determinaram fosse feito pela equipe de design. Nesses casos só restará ao designer dizer o famoso eu te disse, ou agora já era, ou porque você está me contando isso agora?

Em outros casos, na medida em que o curador vai se aclimatando com as características e particularidades do edifício, ele vai entendendo que as sugestões 
que são oferecidas ela equipe de design do museu são as mais adequadas. O curador percebe que não conseguiu imaginar coisas que já havíamos pensado antes muito bem. Carla Marins citou o exemplo da exposição América do Sul - A Pop Arte das contradições, uma coletiva de artistas brasileiros e argentinos montada no salão 2.4.do museu, aberta ao público nos meses de julho e agosto de dois mil e treze. A curadoria foi assinada pelo brasileiro Paulo Herkenhoff e pelo o argentino Rodrigo Alonso. A entrevistada lembrou que a equipe de design foi prontamente acatada na sua sugestão de pendurar no vão central uma das obras expostas, um avião que servia de cruz para o cristo. A peça reinou nesse local e se tornou central, icônica da exposição.

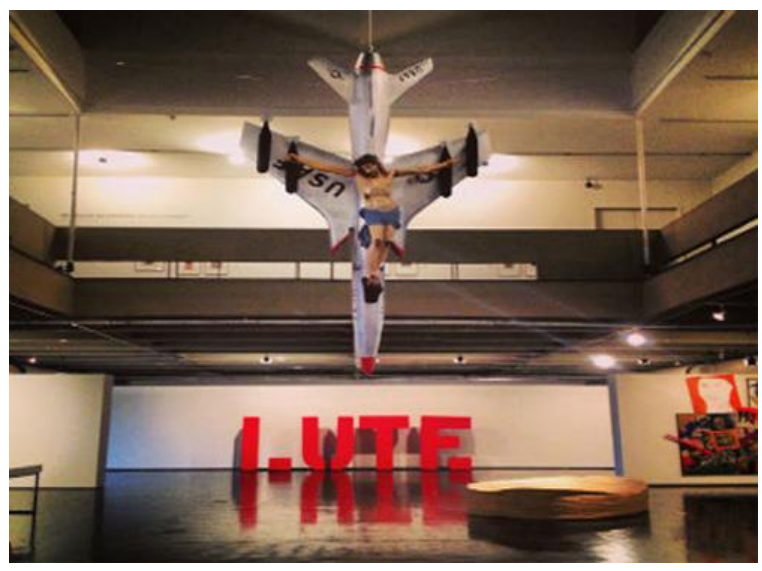

Figura 6. Exposição América do Sul - A Pop Arte das contradições.

http://www.rioecultura.com.br/expo/expo_resultado2.asp?expo_cod=1927

Houve ainda o exemplo ocorrido na exibição das obras do escultor australiano Ron Mueck em 2014. Carla Marins relatou que o assistente do artista veio trabalhar com o departamento de design do MAM fazendo a vez do curador. Houve um embate sobre o local onde a obra Still life de 2009 seria pendurada. Os designers queriam o gigantesco e impactante frango pendurado no salão monumental do museu desde a fase projetual da exibição. $\mathrm{O}$ assistente do artista, ainda em Londres, era contrário, queria a obra pendurada em um ambiente menor e mais baixo do prédio. A equipe de design tinha ciência de que a escala da obra não se prestava ao que o assistente queria. $\mathrm{O}$ assistente só entendeu isso quando chegou pessoalmente ao MAM. Como explicou a entrevistada, os designers da equipe conheciam tão bem o museu que era como se soubessem, a priori, para onde as obras iriam caminhando sozinhas. Às vezes o curador não sabe isso, então 
os designers precisam dizer de forma muito clara. Nem sempre o curador entende, às vezes ele só entende na situação prática, vendo.

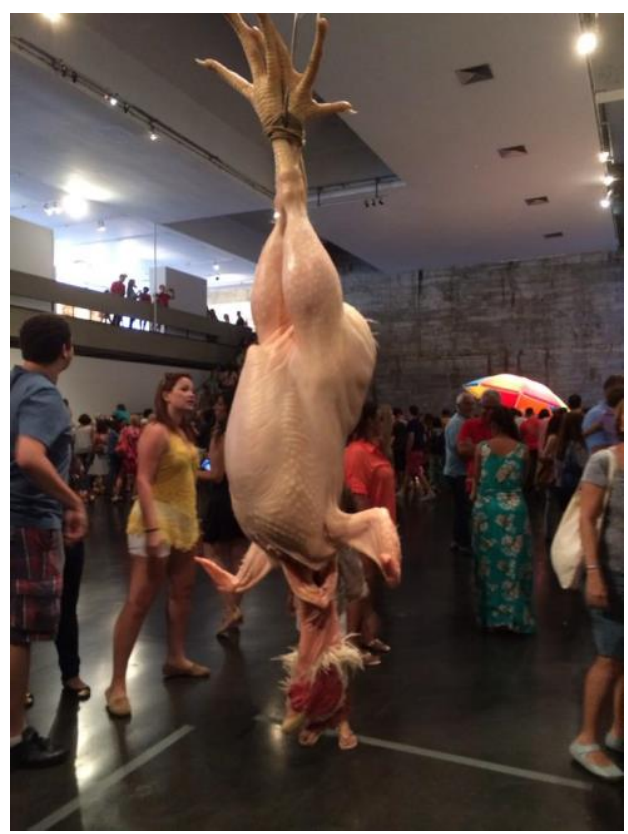

Figura 7. Still Life de Ron Mueck no MAM. https://keepit2u.files.wordpress.com/2014/04/10152689_626023987484056_923 995720_n.jpg. Acesso em 22/11/2016

Prosseguindo a entrevista, Carla Marins ensinou que na maior parte das vezes, o briefing vem muito completo. Segundo opinou, as exposições mais complexas de serem realizadas são as que exigem mais tempo de preparação, normalmente as internacionais. São as mesmas que envolvem grandes somas de seguro e transporte. Geralmente contam com lista definida das obras a serem exibidas e trazem as informações úteis sobre elas tais como: dimensões, suportes, particularidades como tamanho, se pode ser tocada, se precisa ser ligada na luz. Todas as informações sobre as obras nos interessam profundamente.

Nossa entrevistada afirmou que o MAM-Rio tem alguns milhares de obras no seu acervo. Entretanto, ela explicou que apesar dos números gigantescos, ao receber uma lista bruta do departamento de museologia, o responsável pelo zelo físico das obras, o departamento de Design sabe o que fazer porque seus designers conhecem demais a trajetória dos artistas e as características de seus trabalhos. Nas exposições internacionais, o departamento de Design recebe esta lista de obras com antecedência muito maior porque tudo tem que ser planejado com 
antecedência muito grande e aí os designers conseguem fazer os melhores trabalhos. Nas exposições que vem de fora, esse planejamento é muito maior e muito mais preciso. Quando se trata do acervo interno, o projeto da exibição vai sendo modificado conforme o curador decide trocar as obras que serão expostas. Fica bom, mas não estava na lista desde o início do projeto e então tudo tem que ser readaptado, mesmo se a montagem da exibição já estivesse pronta. Carla Marins parece convicta ao afirmar que o curador é o responsável pela escolha de todas as obras, sempre. Isso é um fato comum, que acontece tanto nas exposições montadas no MAM-Rio como em outras instituições.

Carla Marins prosseguiu a entrevista informando que a exposição que julga ter sido a mais difícil que montou no MAM-Rio foi a retrospectiva da obra de Alberto Giacometti, com curadoria de Véronique Wiesinger. ${ }^{67}$ A mostra, que contou com mais de duzentas obras realizadas pelo artista suíço no período de 1910 a 1960, foi inaugurada em dezessete de julho de 2012 e encerrada em dezesseis de setembro do mesmo ano. ${ }^{68}$ Nossa entrevistada afirmou que de fevereiro a julho se desenvolveu a fase gestacional da exibição. Foram seis meses de trabalho projetual porque o grau de exigência técnica era elevado, a quantidade de obras era avassaladora envolvendo valores milionários e seguro caríssimo. Exigiu-se ainda que a mostra fosse orientada cronologicamente nos três andares da exposição. Difícil de fazer, a exibição era cronológica e vertical, não linear, então o percurso não podia falhar dentro das 256 obras, conforme explicou a designer. Perguntados se conseguiram fazer com que o público seguisse necessariamente esse caminho, Carla Marins e Rafael Rodrigues responderam que os visitantes podiam ir por outro lado, mas o caminho foi construído para ser cronologicamente seguido até a morte do artista - seus últimos trabalhos. As salas do museu foram montadas assim, o que não impediu que a pessoa que passasse pela catraca do foyer do MAM e decidisse ver de trás para frente, começasse a visitação pelo terceiro andar - da morte para o nascimento. No MAM-Rio, não há como se obrigar o visitante a nenhum trajeto. Mas Carla Marins frisou que essa permeabilidade acontece especificamente no MAM-Rio. No museu Nacional de

\footnotetext{
${ }^{67} \mathrm{http}: / /$ oglobo.globo.com/cultura/exposicao-reune-282-obras-de-giacometti-no-mam5492412. Acesso em 22/11/2016.

${ }^{68} \mathrm{http}: / /$ www.base7.com.br/portfolio/ver/145. Acesso em 22/11/2016.
} 
Belas Artes ou no Museu de Arte do Rio (MAR) ela afirmou que isso não vai acontecer, pois os visitantes encontram uma sala seguida de outra sala e para se ver a segunda sala, há que se passar pela primeira. Transcrevem-se aqui palavras de Carla Marins: O MAM é um museu sem paredes porque é sem limites, porque aqui nada é impossível. Isso é o bom e o ruim do MAM, o que facilita e o que dificulta. Essa característica do MAM gera vários benefícios, mas ao mesmo tempo exige recursos de design, de projeto.

A entrevistada opinou que a mostra Giacometti foi trabalhosa, mas resultou em uma ótima experiência para os designers do MAM-Rio, porque essas exposições que vêm de fora trazem para nós o contato com outros diretores e curadores de outras instituições para percebermos como eles trabalham, aprender com eles e também ensinar um pouco.

A entrevista abordou em seguida a exposição Marginalia 1 que a equipe de Design do museu montava em junho de 2016, a retrospectiva do trabalho de Rogério Duarte, celebrado designer gráfico brasileiro, com curadoria partilhada de Manuel Raeder, alemão e também designer gráfico, do próprio artista e de seu filho, Diogo Duarte. À época a exposição oferecia um desafio para a equipe, qual seja, a dificuldade de se articular os conflitos de opiniões e de desejos entre o expositor e o curador. A controvérsia girava em torno de uma mesa, mobiliário projetado pelo curador alemão especificamente para a exibição, mas que era fonte de dúvidas para o expositor. A mesa de dimensão expressiva era uma presença marcante que poderia vir a contribuir para os objetos nela expostos ou, ao contrário, eclipsá-los.

A mídia de promoção do evento divulgou que a mostra reunia cerca de setenta obras, dentre capas de discos, publicações e cartazes, incluindo trabalhos inéditos e objetos pessoais, como notas, esboços, rabiscos, fotos, vídeos, estudos e poemas. ${ }^{69}$ Percebia-se que os objetos que estariam dispostos na enorme mesa eram de formato pequeno e ricos em detalhes enfim, coisas que costumam ser seguradas nas mãos e observadas de perto.

Conforme explicou Carla Marins, a mesa era esteticamente interessante, mas como objeto expositivo poderia vir a não funcionar tão bem, pois sua área era

\footnotetext{
${ }^{69} \mathrm{http}: / /$ www.artrio.art.br/pt-br/noticias/mam-rio-apresenta-obra-de-rogerio-duarte. Acesso em 24/11/2016
} 
muito grande e assim a relação de distância entre o observador e o bem exposto também seria muito grande, especialmente em se tratando de objetos pequenos. $\mathrm{O}$ visitante poderia ter dificuldade de identificar os trabalhos de Rogério Duarte que estivessem dispostos no móvel. O expositor queria a abordagem tradicional, livros expostos em uma vitrine que as pessoas pudessem olhar diretamente, mas sem tocá-los já que são livros esgotados, que não se acham mais.

O curador do MAM-Rio e Manuel Raeder, juntos, explicaram para o artista que seria interessante considerar uma proposição nova. O conceito de que a obra de Rogério Duarte era constituída majoritariamente por objetos reproduzíveis ou que foram reproduzidos em alta tiragem e, portanto, manuseados por muitas pessoas, excluía a ideia tradicional da peça de arte única que quando exposta em museus normalmente clama por vitrines para sua maior proteção. Assim, a mesa projetada para abrigar os objetos refletiria simbolicamente a intensa circulação da obra do artista entre o público, sendo o display principal e fundamental naquela exposição. Ela seria disposta no centro do salão e ao seu redor seriam pendurados nas paredes cartazes criados pelo artista. Rogério Duarte, contrariamente, entendia a mesa como um trabalho assinado por outro designer dentro da exposição dele. Ele queria um projeto neutro onde não houvesse qualquer tipo de competição ao seu trabalho.

A exibição em referência estava a cinco dias de ser inaugurada e a desavença ainda existia. Carla Marins então ensinou: exposição tem isso: adrenalina. Explicou que a equipe de design do museu iria atuar durante a semana tentando dar soluções para o embate entre o curador e o artista. Por meio de fotos verificou-se que a proposta da mesa foi a que prevaleceu. 


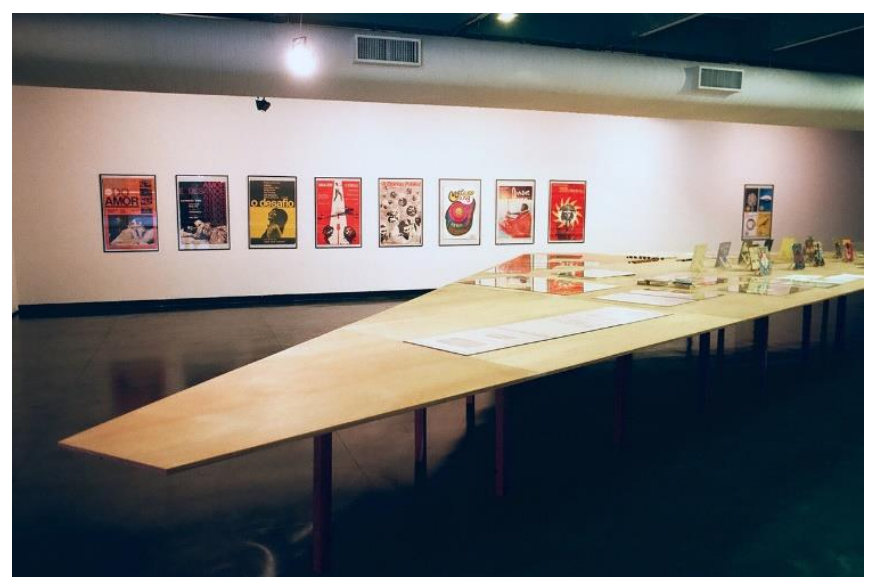

Figura 8. Mesa da exposição Marginalia 1.

http://www.manuelraeder.co.uk/marginalia-1-mam.

Acesso em 22/11/2016

A questão relativa ao papel do designer de exibições continuou na pauta da entrevista realizada com Carla Marins e Rafael Rodrigues. A mostra $O$ Fim da Matéria do artista mexicano Damián Ortega, sob curadoria de Luiz Camillo Osorio, exposta no MAM-Rio de quinze de abril a quatorze de junho de dois mil e quinze, propunha que artesãos/artistas que trabalham nos barracões do carnaval carioca retirassem pedaços de um cubo de isopor de $6 \mathrm{~m} \times 6 \mathrm{mx} 6 \mathrm{~m}$ para transformálos em obras ícones da história da escultura durante todos os dias do evento. ${ }^{70}$

Carla Marins relatou que o curador pôs aos designers do museu o seguinte problema: os objetos que seriam expostos não eram já prontos, mas seriam feitos, construídos dentro e durante a exposição. A exposição se transformaria todo dia, na feitura das suas obras, no meio dos visitantes convocados para assistir o processo. Não seria uma mostra do tipo tradicional que permanece igual desde o dia de sua inauguração até o dia de seu fechamento.

Criou-se para a equipe de Design um problema expositivo resultante dessa feitura diária das esculturas a serem expostas. $\mathrm{O}$ que acontece com uma peça que ainda vai ser construída? Como respondeu Carla Marins, ela gera algo que o museu tem horror: a poeira. A sujeira, e nos aqui temos horror à sujeira. Explicou que a antipatia se justifica por uma questão fundamental: o sistema de ar condicionado do MAM-Rio é integrado. Não se consegue fechar as saídas de

\footnotetext{
${ }^{70} \mathrm{http}$ ://brasileiros.com.br/2015/04/mam-rio-traz-nesta-quarta-feira-15-mostras-artistamexicano-damian-ortega-sobre-historia-da-escultura-e-sobre-psicanalise,disponível $24 / 11 / 2016$
} em 
vento ou desligar um único segmento do ar. Ou se liga um andar inteiro ou não se liga. Quando ligado, o ar-condicionado por ser integrado iria dispersar a poeira pelo museu.

A questão da limpeza das salas de exibição de museus que havia sido abordada na entrevista realizada com Cintia Kury foi novamente tratada agora por Carla Marins pela sua importância para os designers de exposições. A designer do MAM-Rio informou que os salões do museu são limpos diariamente, todo dia a equipe de limpeza passa pano no chão que mede $3.000 \mathrm{~m}^{2}$, só em um dos andares. A importância da limpeza no referido museu se deve ao fato de o pó não poder subir pois como o ar refrigerado é integrado, ele puxa aqui e sopra acolá.

Transcreve-se a seguir a solução encontrada pelo departamento de Design, nas palavras de Carla Marins:

O trabalho de esculpir isopor gera muita sujeira. O departamento de museologia ao saber dessa questão se arrepiou até o último fio de cabelo. Isso é contra o que o MAM precisa no dia a dia. E isso gerou um problema de design muito claro: como fazer essa exposição? A solução foi: projetou-se uma área dentro do salão, um ateliê (apelidado de aquário) fechado, porém aberto e visível. Ele é fechado todo em plástico, tem alguns respiradores em plástico e sua porta é tal como as de câmaras frigoríficas. Era a única forma. Tinha que ter uma porta muito larga porque as peças que vão passar são enormes, de três metros. Ele é totalmente forrado, não há comunicação entre a grelha do ar e o aquário, forramos seu teto todo, iluminamos antes e deixamos tudo pronto. Há instrumentos cortantes que o público não tem que ter contato, por isso ser uma área fechada, porém aberta, porque eles (os escultores) mexem com substâncias químicas, que cheiram e o ar tem que circular, então foi feito esse aquário no qual o ar circula.

Carla Marins esclareceu que o que se colocou inicialmente como um projeto difícil de resolver foi solucionado de maneira simples.

Sempre a solução simples é a melhor, ninguém quer inventar nada mirabolante, as soluções mais simples de design são ótimas para as exposições, foi a primeira coisa que veio à cabeça - construir um aquário, uma bolha. Eles têm toda a liberdade, tudo é forrado e ainda bem, pois já viu como está o chão? (...) e temos que fazer com que os artistas se sintam bem, pois estão trabalhando lá de terça a domingo. A gente construiu para eles um ambiente de trabalho que protegesse o museu da sua sujeira e que fosse possível que as pessoas os vissem trabalhando, o grande "lance" dessa exposição é ela acontecer a cada momento e eles (os visitantes) verem como é feita. As obras que estão fora (do aquário) já estão se comunicando, dialogando com as que ainda estão sendo prontas.

Por fim, Carla Marins explicou que os designers do museu optaram por uma escolha arquitetônica ao escolherem uma área do salão que se adequasse mais 
facilmente a montagem do dito aquário. Tratou-se de uma área cujo teto era baixo, localizada embaixo de uma escada. Enfim, a entrevistada informou que o ateliê foi posto em uma área menos nobre, mas com características técnicas mais fáceis para se construir um aquário. Essa solução possibilitou ainda que uma área grande do salão se destinasse a abrigar as esculturas de isopor de seis metros de altura que reinaram exuberantes no espaço. Carla Marins concluiu que no seu trabalho nunca um dia é igual ao outro.

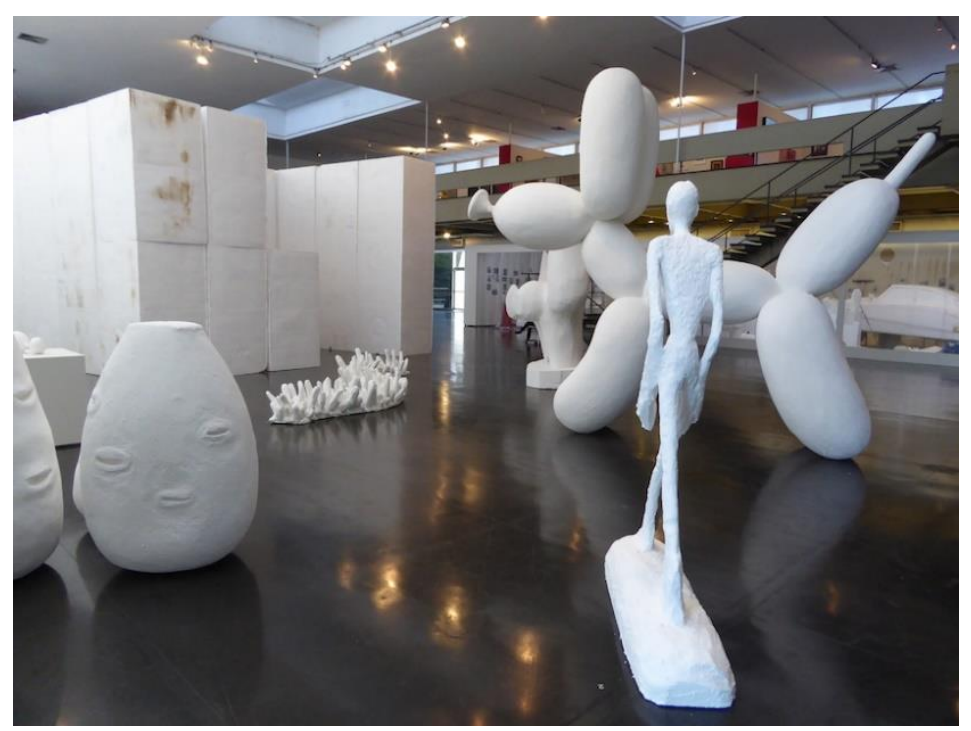

Figura 9. "Aquário" embaixo da escada.

http://www.artblogcologne.com/wp-content/uploads/2015/08/Ausstellung-

Damian-Ortega-MAM-Rio.jpg. Acesso em 24/11/2016. ${ }^{71}$

Segundo Carla Marins, os designers do MAM-Rio trabalham para que o público tenha a melhor experiência de aproveitamento possível. Assim, montam as exibições pensando no público, mas sem nada impor. Afirmou que o trabalho do designer de exibições é interessante porque ele projeta para o público e depois do projeto entregue, ele se retira. Não estamos ali no dia a dia, no dia a dia quem está ali é o nosso filho. Expôs ainda o paradoxo da prática: A gente considera o tempo todo a pessoa (do visitante), mas não trabalhamos com ela no final das contas.

${ }^{71}$ Se observa ao fundo da foto o ateliê dos escultores montado embaixo da escada e as enormes esculturas no salão. 
Embora o cotidiano do trabalho do designer de exibições não envolva o contato direto com os visitantes dos museus, a experiência advinda da resposta do público geralmente serve como importante lição para projetos futuros. Nossa entrevistada informou que depois que a equipe de design do MAM-Rio entrega as exposições no primeiro dia, montadas para o público, não volta mais lá. O feed back sobre como o público está se comportando vem do gerente do salão de exposição. Afirmou que esse feed back é muito importante, isto é, quando ele vem. Quando vem nós aprendemos com as nossas escolhas. Quando não vem, consideramos que deu tudo certo.

Carla Marins enfatizou o interesse que tem pela resposta das pessoas às montagens realizadas no MAM-Rio. Citou o exemplo da mostra Louise Bourgeois: O Retorno do Desejo Proibido, com curadoria de Philip Larratt-Smith, organização do Studio Louise Bourgeois de New York e projeto expográfico feito pelo Instituto Tomie Ohtake, inaugurada em setembro de 2011 no referido museu carioca. $^{72}$

A designer contou que embora o departamento de Design do MAM-Rio tenha fornecido as características do salão, as plantas dos espaços e o know how, sua atuação se limitou a aprovar e a supervisionar o projeto. A proposta do Instituto Tomie Ohtake de pintar os tablados de cinza claro não funcionou porque as pessoas queriam ver de perto as esculturas de vulvas e de falos e, consequentemente, os tablados de cor clara ficavam sujos de marcas de pés e todos os dias era preciso passar pano e limpá-los. Nem mesmo a solicitação do monitor de sala pedindo para que as pessoas não pisassem nos tablados impedia esse comportamento indesejado. Assim, apenas depois de aprovada a planta, montada e aberta ao público a exibição que ela e toda a sua equipe aprendeu que, na frente das esculturas de falos e de vulvas da artista, as pessoas pisavam invariavelmente nos tablados colocados para conter a aproximação das pessoas.

Carla Marins repetiu: aprendemos com o comportamento do público o tempo todo e refletiu que a escolha poderia ter sido outra para conter o público. Entretanto, o incidente ensinou-lhe que determinadas obras chamam mais a atenção do público do que outras e as pessoas querem realmente vê-las de perto. A

\footnotetext{
${ }^{72} \mathrm{http}$ //www.timeout.com.br/rio-de-janeiro/arte/events/31/louise-borgeois. Acesso em $24 / 11 / 2016$
} 
entrevistada informou que sua equipe sempre demarca um espaço de oitenta centímetros (um braço estendido) entre o objeto exposto e o visitante, mas que algumas obras geram uma relação de desejo no público e nesses casos há que se pensar melhor em como se fazer esse distanciamento, em como se criar uma maior proteção. Cabe aos designers de exibições de arte pensar constantemente nas diversas soluções aptas a resolver questões desafiadoras dos projetos expográficos.

Quando foram perguntados sobre o material publicitário das mostras do MAM-Rio, Carla Marins respondeu que as peças gráficas para divulgação também faziam parte do trabalho da equipe de Design do museu e que elas tinham que ser bonitas e atrativas. Para tanto, sempre procuravam escolher os trabalhos mais significativos dos artistas, que normalmente chamam mais atenção e que mostram algo novo, mas que isso nem sempre é possível, nem sempre é fácil. Citou o material publicitário produzido para a exposição de Rogério Duarte. Foi usado seu famoso cartaz criado para o filme Deus e o Diabo na Terra do Sol que é tido como um dos cartazes mais bonitos de toda a cinematografia brasileira. A designer explicou que foi uma escolha natural, praticamente obrigatória. O artista, insatisfeito, perguntou porque sempre se decidia pelo mesmo cartaz e demorou para aceitar a sugestão. A equipe de Design do museu insistiu na escolha porque apesar da obra de Rogério Duarte ser amplamente conhecida, especialmente as capas de discos que criou, o cartaz com Othon Bastos em frente da roda dentada do sol é o seu trabalho mais divulgado. A equipe de design do museu preferiu não arriscar por entender que as pessoas imediatamente associam o nome do artista ao emblemático cartaz do filme de Glauber Rocha. Imagem recente homenageando o artista no seu falecimento reforça a suposição da equipe. 


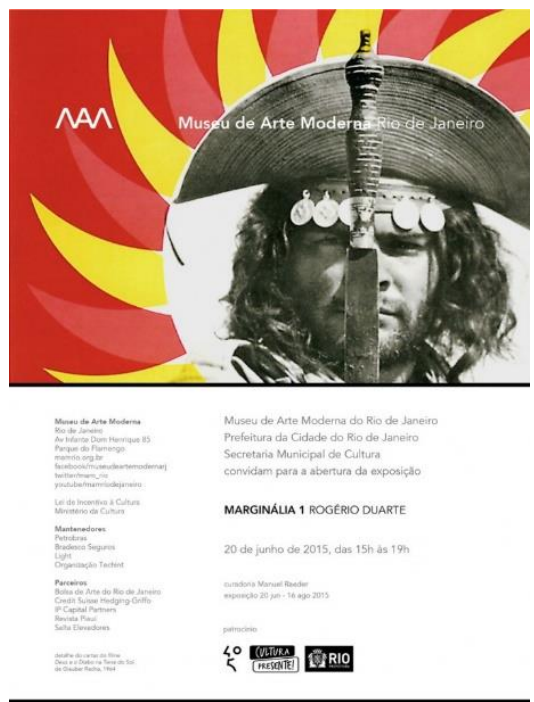

Figura 10. Convite para exposição Marginália 1.

http://premiopipa.com/wp-content/uploads/2015/06/ImageProxy-1e1433793691899.jpg. Acesso em 28/11/2016.

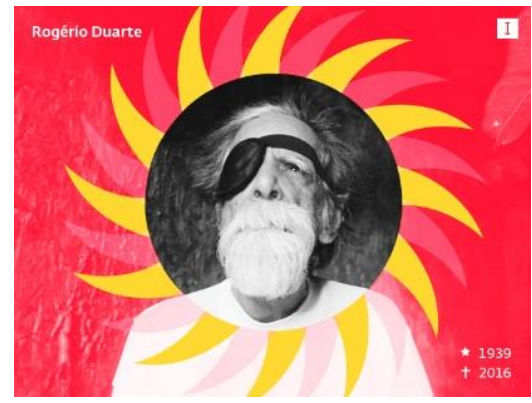

Figura 10.1 Homenagem a Rogério Duarte.

http://www.interbrandsp.com.br/tag/musica/. Acesso em 28/11/2016.

No caso da mostra Temporama de Dominique Gonzalez-Foerster, a própria artista mandou imagens suas para a equipe de design escolher e usar nos prospectos de divulgação. Como relatou Carla Marins, recebemos todas as imagens e em nenhum momento tentamos esconder nada, tentamos usar as imagens em sua integralidade, plenitude. A imagem escolhida foi a que retrata a artista loura, lábios pintados de batom vermelho, molhada e nua. Na opinião da designer, isso atrai bastante. Informou então que a referência da construção da peça gráfica dessa exposição havia sido a capa do disco Bedtime Stories da cantora Madonna, da década de 1990, absolutamente conhecida do público cuja paleta cromática era similar àquela que estava presente na foto da artista francesa. 
Dessa maneira, o enquadramento do convite e a sua relação com a tipografia foi pensada para parecer ao máximo com a capa do mencionado disco.

Segundo justificou Carla Marins, a peça gráfica foi pensada para ser a mais apetitosa possível, fisgar o maior número de peixes. A seguir comentou com sinceridade:

Obviamente a artista não sabe disso, mas sabemos que as capas desses discos são conhecidas e as pessoas vão olhar, reconhecer o signo e vir à exposição. Procuramos isso da forma mais bem-humorada possível para atrair as pessoas e os convites ficaram super bons, todos gostaram, a artista achou super!

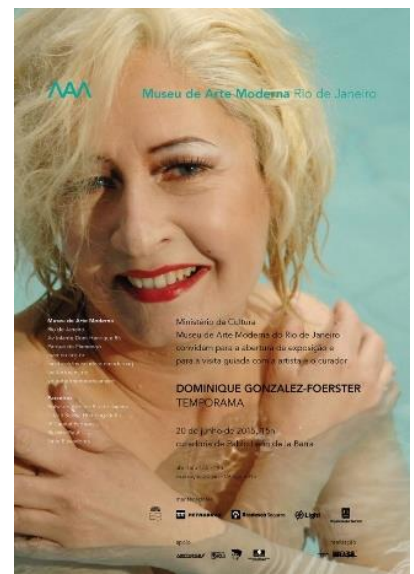

Figura 11. Convite da exposição Temporama.

http://premiopipa.com/wp-content/uploads/2015/06/ImageProxy-2-

e1434137789985.jpg. Acesso em 28/11/2016.

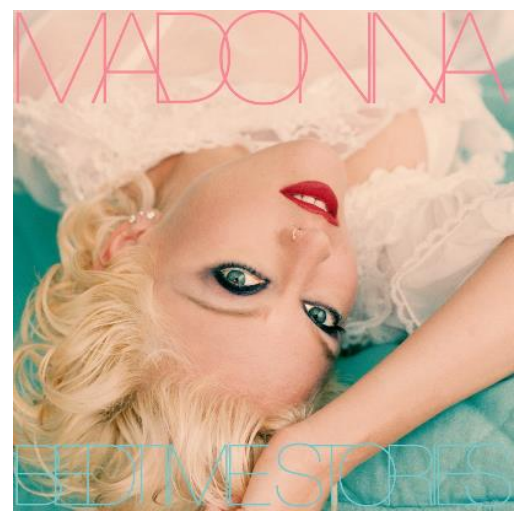

Figura 11.1. Bedtime Stories.

http://outradiscografia.tumblr.com/post/64034444025. Acesso em 28/11/2016.

A entrevistada julga que os designers devem lançar mão de recursos para atrair as pessoas, logo, quanto mais conhecido ou instigante for o signo, melhor. 
Ao contrário, a peça de divulgação da mostra de Damião Ortega foi um verdadeiro fracasso, segundo informado pela designer, porque o artista tinha uma determinada ideia a respeito do trabalho que iria desenvolver no MAM e mudou de ideia durante a feitura da exposição, quando o convite já tinha sido emitido. Carla Marins comentou que o artista escolheu escultura sua de uma boca asteca aberta como peça gráfica de divulgação da mostra carioca enquanto ainda estava no México. Muito embora ele e o curador tivessem sido alertados pela equipe de design que essa imagem não era afim à cultura brasileira, não chamava atenção e poderia mesmo vir a ser confundida como sendo a representação de um monstro de boca aberta, ambos insistiram na escolha. Ao chegar ao Brasil, o artista mudou o conceito de sua exibição. Entretanto, o convite que já havia sido impresso não foi alterado e exemplificou o que se entende por anti-design, pois transmitiu a ideia errada deque a exposição se constituía de esculturas astecas de isopor, era esteticamente feio e não guardou afinidade alguma com o público. Como concluiu a entrevistada, então eles vão aprendendo pedagogicamente com os próprios erros, tal como nós.

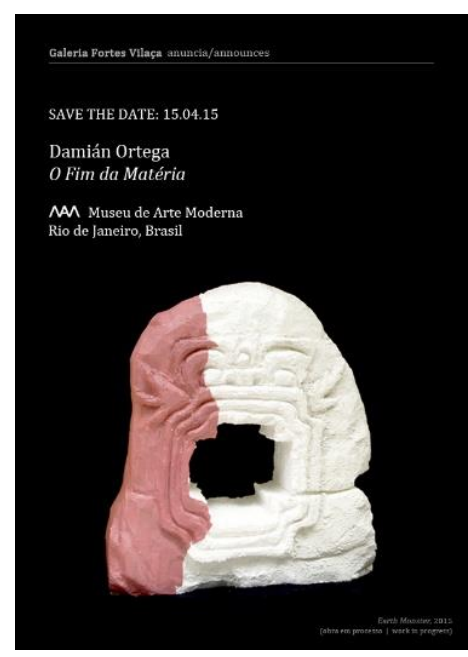

Figura 12. Convite para exposição O Fim da Matéria.

https://tcmagazine.files.wordpress.com/2015/03/damianortega.jpg. Acesso em 26/11/2016.

Ainda sobre o papel a ser desempenhado pelo designer de exibições que trabalha em museus de arte, Rafael Rodrigues abordou a questão da desmontagem que também deve ser prevista no projeto, pois julga que é importante projetar já se pensando na próxima exposição que ocupará o mesmo espaço, especialmente no 
caso do MAM-Rio onde as arquiteturas de suporte são constantemente construídas especificamente para cada evento e destruídas ao final, tal como mandalas. Essa preocupação se justifica ou pela pouca flexibilidade do orçamento da exibição seguinte e por motivos financeiros os designers precisam reaproveitar o que for cabível, ou em razão da exiguidade de prazo para a próxima montagem, o que leva a equipe a tentar fazer com que a estrutura já montada não tenha vida tão efêmera.

O MAM-Rio conta com um amplo mobiliário para a montagem das exposições por seus designers. Todo esse material fica depositado no subsolo e nos segundo e terceiro andares do prédio. Há os painéis já mencionados, vitrines, bases, mesas, plataformas, tablados, cúpulas, vidro, prateleiras. Como explicou Carla Marins, o MAM-Rio é um museu completo, o que não impede que às vezes se construa uma peça nova para uma determinada mostra, que irá provavelmente integrar o acervo mobiliário do museu posteriormente. Assim ocorreu com as peças de madeira bruta e de concreto criadas para a exposição de Amílcar de Castro que foram guardadas por dialogarem perfeitamente com o famoso chão negro e com as superfícies brancas há décadas usadas para a disposição dos objetos exibidos nos salões da instituição. Segundo a designer, foi uma surpresa muito interessante e agradável elas (as peças) estarem expostas sobre uma tonalidade de madeira. Também foi o caso da mesa de madeira da exposição Marginália 1, feita de compensado naval bruto, sem nenhum tratamento. A entrevistada considerou que o MAM-Rio responde muito bem ao material puro, sem subterfúgios, até porque o museu é feito assim, é a arquitetura moderna, material de fácil uso. Em seguida a designer opinou que o uso de andaimes servindo de estrutura para quadros ou o uso de pallets, apesar da crueza dos materiais, não deu certo porque há a questão do espaço, de sua dimensão e de suas características. Logo, se a peça for muito grande, ocupando muito do espaço, cria claustrofobia. $\mathrm{O}$ ambiente fica poluído, amontoado de coisas.

Indagados se a equipe de design buscava criar mini espaços de cubos brancos nos salões apesar do museu ser tão aberto, responderam que sim, se essa fosse a ideia da exposição. Entretanto, Carla Marins explicou que o MAM-Rio foi feito para destruir o cubo branco, mas, se a exposição assim o quiser, ele poderá ser mantido. 
Questão que normalmente exige a atenção do designer de exibições é a relativa à luz que incide nos prédios onde são montadas as exposições de arte. Segundo Carla Marins, no caso do MAM-RIO, quando o museu foi feito predominava outra ideia museológica. A permeabilidade da luz através de todas as janelas do prédio era vista como um problema, algo ruim. No projeto original de Reidy, o MAM-Rio contava com persianas de alumínio que controlavam a eventual incidência direta da luz externa nos salões de exibições, mas que foram queimadas durante o incêndio ocorrido em julho de mil novecentos e setenta e oito. Hoje, o museu não tem mais um controle direito sobre a incidência da luz, entretanto, o prédio foi projetado de forma que a incidência da luz natural externa fosse a menor possível nos espaços expositivos. Reidy foi preciso a ponto de posicionar o prédio de forma a impedir totalmente a incidência da luz do sol dentro dos salões durante os meses de verão do Rio de Janeiro. Também os vidros fumês dos dois lados do prédio foram forrados por uma película que oferece $70 \%$ de proteção contra raios infravermelhos. A luz natural que entra no MAM é a de inverno, pouca, oblíqua e incide somente em um lado do prédio, o que não impede que os vidros que são atingidos por esses raios estourem repetidamente. Se as janelas estão fechadas, o sol incidindo e o ar-condicionado está ligado, isso cria uma diferença térmica que faz com que os vidros estourem todos os anos. O projeto original do MAM-RIO não previa o uso de ar condicionado, suas janelas ficavam abertas o que proporcionava a ampla circulação de ar no interior do prédio. Mas na medida em que foram mudando as exigências e as características museológicas, o museu também foi mudando.

De acordo com o descrito, Carla Marins resumiu que a equipe de design do MAM-RIO tenta controlar a incidência direta da luz de inverno no interior do prédio com o vidro fumê, a película protetora e com a construção de arquiteturas móveis. Explicou que a equipe também tem problemas de contenção da luminosidade quando são expostos trabalhos em papel, quando são trabalhos muito delicados e a quantidade de luz tem que ser muito baixa ou ainda quando há projeções. É comum o recurso ao cubo branco nesses casos a fim de se escurecer naturalmente um espaço que é permeado por janelas. Tudo na verdade se coloca como problema de design, por isso temos que conhecer profundamente qual a obra que vai ser exposta. 
Chegando ao final da entrevista, Carla Marins enfatizou o quanto aprecia a sua profissão.

Acho o melhor trabalho do mundo, sabia? Adoro o que faço porque um dia nunca é igual ao outro. (...) e tentamos passar para as pessoas, por meio das peças gráficas, e dentro da identidade visual do museu, aquela característica do artista. (...) e assim nos reinventamos todo dia.

Por identidade visual do museu a entrevistada se referiu à paleta de cores, à família tipográfica e à escala de formatos usualmente aplicada nas peças gráficas do museu. A mera presença do logotipo da instituição não basta para conferir ao material gráfico a identidade mencionada. A esses elementos fixos que criam a identidade do museu se aliam as particularidades dos artistas.

Perguntados finalmente qual seria a especificidade da atividade do designer de exibições no processo de elaboração e montagem de exposições em museus de arte, Carla Marins respondeu embasada em cena do filme Pulp Fiction ${ }^{73}$ :

Um de nossos estagiários definiu o papel de nosso departamento com uma precisão tão grande, disse que em um filme de Tarantino, quando acidentalmente John Travolta atira no banco de trás e mata o sujeito que lá estava e que suja de sangue seu banco (...) o carro é levado para a casa do Quentim Tarantino que fez uma ponta e é chamada uma pessoa para resolver o problema, que é o Harvey Keitel. Quando ele chega lhe é perguntado: o que que você faz? "I solve problems".Esse estagiário definiu o papel do nosso departamento em relação ao MAM exatamente como aquele sujeito personagem do Harvey Keitel que chega de terno e ao se apresentar diz que ele resolve os problemas. Foi a definição mais perfeita sobre nosso trabalho, a gente faz de tudo. Cuidamos do ambiente, peça gráfica, a gestação é total, a criança nasce inteira, criamos todas as soluções desde o convite que a pessoa vai receber até a etiqueta que vai estar ao lado da peça que se expõe, tudo passou por um problema de design que foi resolvido aqui nessa sala. Nós damos soluções, nós resolvemos problemas.

\subsection{O sistema de exibição de Karl Heinz Bergmiller.}

O presente subcapítulo se baseou inteiramente em texto de Maria Stella Tedesco Bertaso e Marcos da Costa Braga intitulado Sistemas expositivos

\footnotetext{
${ }^{73}$ Pulp Fiction, Quentin Tarantino, 1994.
} 
projetados por Bergmiller. O caso do MAM-RJ. Outros documentos escritos sobre o assunto ainda não foram encontrados até a presente data.

Os sistemas expositivos projetados por Bergmiller merecem ser estudados e conhecidos pela importância inovadora que representaram desde sua criação em termos de logística expositiva e de sustentabilidade para o Museu de Arte Moderna no Rio de Janeiro, por servirem de referência para diversos museus brasileiros até os dias atuais e também pela repercussão que alcançaram internacionalmente à época.

Durante as entrevistas colhidas para o presente trabalho, esses sistemas foram repetidamente lembrados, seja por Ana Luísa Nobre ao se referir à intenção do Instituto Moreira Salles (IMS) de criar um sistema expositivo modular e reaproveitável para suas mostras; seja por Cintia Kury ao relatar a eficiência com que Bergmiller calculava e elaborava os projetos expográficos das mostras do MAM-Rio ou de como Zúñiga trouxe para o Museu da República a experiência adquirida no período em que integrou o departamento de design do MAM-Rio; seja por Sylvia Steinberg que também atuou como designer da lendária equipe de Bergmiller, participando ativamente dos projetos de elaboração e de montagem de exibições do museu carioca nas décadas de 1970 e 1980. Finalmente, Carla Marins ao falar sobre a mostra Temporama fez alusão à mobilidade dos painéis expositivos utilizados permanentemente pelo museu.

Como descrevem os pesquisadores Bertaso e Braga (BERTASO \& BRAGA, 2010) o projeto do MAM-Rio previa a construção de duas edificações ocupando uma área total de quatorze mil metros quadrados. Uma edificação seria dedicada à escola e à administração do museu, outra ao grande bloco de exposições permanentes e temporárias. Descrevem quanto à estrutura arquitetural do museu que $O$ espaço deveria ser fluido e garantir várias possibilidades expositivas, possuía alturas internas diversas conferindo as flexibilidades horizontal e vertical. Dessa maneira, o espaço expositivo poderia ser organizado de maneira a garantir grandes áreas livres ou a formação de pequenas salas que privilegiassem a intimidade entre o espectador e os objetos expostos. Para que essa flexibilidade fosse possível, mostrava-se necessário que também os suportes destinados aos projetos expográficos pudessem assumir configurações variadas.

Tal como já mencionamos anteriormente, o Instituto de Desenho Industrial do MAM-Rio (IDI) foi criado em 1968 por Goebell Weyne e por Karl Heinz 
Bergmiller. No período de 1968 a 1977 em que Bergmiller trabalhou no IDI como coordenador das exposições tanto de arte como de Desenho Industrial, ele desenvolveu e aperfeiçoou os sistemas expositivos que seriam utilizados nas exibições montadas pelo museu carioca até hoje. Esses sistemas incluíam suportes, vitrines e embalagens multifuncionais de armazenamento e transporte para uso em exposições itinerantes que podiam ainda exercer a função de suportes de comunicação.

Os sistemas expositivos em menção foram inicialmente desenvolvidos em mil novecentos e sessenta e sete, após cinco meses de elaboração, tendo sido testados e aprovados quando da exposição retrospectiva da obra de Lasar Segall nesse mesmo ano, inaugurando o Bloco de Exposições no dia 30 de outubro. Antes dessa data, as exposições apresentadas pelo MAM aconteciam no denominado Bloco Escola. ${ }^{74}$

Os pesquisadores informam que Bergmiller projetou um sistema expositivo modular, composto por painéis leves e móveis ao invés de muros fixos. O designer buscava desenvolver um sistema que se adequasse a qualquer tipo de exposição que se desejasse montar nos salões do museu, podendo atender até mesmo a montagem de mais de uma mostra concomitantemente.

Os painéis desenvolvidos assumiram formas de $\mathrm{L}, \mathrm{U}$ ou $\mathrm{Z}$ e por serem modulares e transportáveis, podiam ser montados de maneiras diversas de forma a criar ambientes cuja característica principal era o movimento ou a limpeza visual. Bertaso e Braga escrevem:

A mobilidade das peças e a facilidade de estocagem eram importantes, valiosas e inovadoras características para a expografia de então. [...] os painéis deveriam permanecer sempre no salão, sendo movimentados, nunca empilhados e encostados, deslizando sobre o piso.

Para cada montagem era feito um cálculo. Cada painel suportava dois quadros de cada lado, portanto, 100 quadros em 25 painéis. Assim era possível estimar a exposição. Partindo-se de um organograma estabelecia-se o número de obras, a quantidade de painéis, o tipo de colocação, sequência e grupos. Com essas premissas montava-se o layout e posteriormente seguia-se a montagem da exposição propriamente dita.

Os montadores recebiam esquemas da disposição de cada obra, com o gabarito de alturas e alinhamentos. Bergmiller pontuava que o esquema de uma montagem precisava funcionar como uma indústria:

\footnotetext{
${ }^{74}$ http://acervo.oglobo.globo.com/rio-de-historias/retrospectiva-de-lasar-segall-inauguramuseu-de-arte-moderna-no-aterro-8926666. Acesso em 12/12/2016.
} 
em quatro turmas, a primeira fixava os painéis, a segunda trabalhava com as ferragens, a terceira fazia a colocação dos quadros e a última identificava as obras. As gravuras eram fixadas sobre os painéis, cobertas com um vidro do mesmo tamanho do painel. As esculturas ou volumes eram posicionados sobre cubos pretos, estes sobrepostos, justapostos, ou de acordo com a necessidade (BERTASO \& BRAGA, 2010:08).

Conforme a composição e agrupamento dos painéis era possível isolar ou juntar as obras. Os montantes poderiam ser aparentes ou não, proporcionando superfícies fracionadas ou contínuas.

Como informam os pesquisadores (BERTASO \& BRAGA, 2010), o sistema expositivo projetado por Bergmiller em 1977 e usado até 1978 era composto pelos seguintes tipos de peças: painel alto medindo 2440x2440x60mm, montante medindo 2440x600x60mm, vitrine alta medindo 2000x2560x60mm, vitrine baixa medindo 1200x1200x600mm, pedestal alto 1200x40x400mm (três cubos de 400mm), pedestal baixo 800x800x200mm. Esses módulos eram montados de maneiras variadas resultando configurações expositivas diversas nos salões do MAM-Rio.

Após o incêndio ocorrido em 1978, outro sistema expositivo projetado por Bergmiller foi desenvolvido e supervisionado por sua equipe de design do IDI. Painéis, vitrines, suportes e colunas medindo $30 \mathrm{~cm}$ no sentido horizontal e $25 \mathrm{~cm}$ no sentido vertical eram os elementos que o compunham e foram inaugurados em mil novecentos e setenta e nove quando da montagem do Salão Nacional de Arte Moderna. Esse novo projeto foi criado tendo por base a experiência de dez anos adquirida durante o uso do sistema anterior e considerava fundamentais as seguintes características:

[...] harmonia formal e estrutural com a obra arquitetônica, versatilidade, facilidade de manutenção, manipulação e montagem, rigidez estrutural, obediência a um conceito sistêmico, utilização de materiais não combustíveis e definição de grandes superfícies móveis (BERTASO \& BRAGA, 2010:10).

Nesse mesmo ano de 1979 o museu publicou o Manual do Sistema de Exposições que, além de descrever as peças do novo sistema, detalhava a metodologia a ser adotada para a montagem das exibições. Segundo escrevem Bertaso e Braga:

Pode-se considerá-lo como uma aula para a montagem de uma mostra competente. Determina-se ali um modelo de cronograma, o 
organograma de funções, os técnicos envolvidos, e cada passo necessário a realização dos trabalhos (BERTASO \& BRAGA, 2010:10).

Tendo-se tratado nos dois últimos capítulos sobre o tema relativo à prática do Design de exibições de arte no Rio de Janeiro, conferindo-se especial atenção ao Museu da República e ao Museu de Arte Moderna do Rio de Janeiro, referenciais cariocas sobre o assunto, passa-se no próximo capítulo a se pesquisar quais são as funções do designer de exibições que atua em mostras de arte e a partir de que momento sua participação se faz necessária. 


\section{O designer de exibições: momento de atuação e suas funções.}

Embora o nome empregado para a carreira sugira que o profissional designer de exibições possua uma formação acadêmica na área do Design, isso não se confirma necessariamente tanto no Brasil como internacionalmente. Jonathan Alger e Leslie Gallery Dilworth, respectivamente presidente e diretora executiva da Society for Environmental Graphic Design (SEGD) ${ }^{75}$ escrevem que a profissão vem recebendo a contribuição de arquitetos, curadores, desenhistas industriais, historiadores (ALGER \& DILWORTH. In.: LORENC et ali., 2007: 06).

Concordando-se com essa caracterização ampla do profissional designer de exibições, aqui se incluindo aquele que projeta e implementa exposições de arte em museus, pode-se classificá-lo como um mediador cultural. Segundo ensina Teixeira Coelho, mediador cultural é todo aquele que exerce atividades de aproximação entre indivíduos ou grupos de indivíduos e as obras de cultura (COELHO, 1997: 248) sendo que o uso dessa expressão se generalizou durante os anos de 1980. Explica ainda que o termo mediador refere-se ao gênero do qual o animador cultural e o agente cultural são espécies.

O mesmo autor escreve:

O mediador cultural é um profissional com formação cada vez mais especializada, obtida, nos países da Europa sobretudo, em cursos de graduação e pós-graduação. Bibliotecários, arquivistas e museólogos - espécies de mediadores - têm uma formação acadêmica específica mais tradicional, embora seus currículos venham passando por alterações substanciais. Os mediadores que atuam em centros de cultura, ou mesmo em bibliotecas públicas e museus sem serem bibliotecários e museólogos, bem como os profissionais do turismo cultural, passam por uma formação variada, conforme a instituição de ensino e o país. Considera-se como núcleo duro dessa formação os estudos das práticas de ação cultural (programação, execução,

\footnotetext{
${ }^{75}$ Somos uma associação de pessoas que criam espaços experienciais, ricos em conteúdo, emocionalmente atraentes, para uma ampla variedade de ambientes, desde hospitais e centros de trânsito até museus e campi educacionais. https://segd.org/what-we-do.
} 
avaliação), estudos de política cultural comparada, gestão de grupos (técnicas de trabalho com grupos em situação de estímulo à criatividade) e estudo de públicos (hábitos, práticas, tendências). Conforme a destinação do profissional, podem fazer ainda parte de sua formação o estudo de história da cultura e da arte, tecnologia da mediação (audiovisual, informática), marketing, arquitetura, arqueologia, etnologia, história das ciências, noções de legislação (COELHO, 1997: 248).

O público que visita exibições de arte em museus geralmente desconhece o longo processo que se distribuí normalmente em cinco etapas para que o evento cultural se torne realidade. Tais fases necessárias para a elaboração de uma exibição são: conceituação, design, planejamento, produção e implementação (SCHWARZ, et ali. 2006: 09).

A atuação do design de exibições se mostra como uma prática possível e desejável em todas as referidas cinco etapas, conforme levantado por meio de entrevistas a designers, arquitetos e produtores culturais que realizam projetos na área de exibição de arte em museus, bienais e conforme confirmado em bibliografia especializada da área.

Entrevistas foram realizadas com sete profissionais que trabalham na área de exibições em geral e de exposições em museus de arte especificamente, e um questionário $^{76}$ preparado pela presente pesquisadora foi submetido a duas arquitetas que também atuam no mencionado Campo, no Brasil, principalmente no eixo Rio de Janeiro, São Paulo e no exterior com projetos realizados em cidades como Nova Iorque, São Francisco, Londres apenas a título de exemplo. Formulava-se a todos a seguinte pergunta: Em que momentos da elaboração de uma exibição o design de exibições pode auxiliar?

Liana Brazil, arquiteta e mestre em Interactive Telecommunications, cofundadora e diretora criativa do SuperUber, studio de criação, atuante na área de Design de Exibições em exposições de arte desde 2002, foi categórica ao responder por escrito que a participação do Design de Exibições se dá durante todo o processo.

Marta Vieira Bogéa, arquiteta, mestre em Comunicação e Semiótica e doutora em Arquitetura e Urbanismo, professora no departamento de Projeto da Faculdade de Arquitetura e Urbanismo da USP e que atua na área de Design de

\footnotetext{
${ }^{76}$ Vide apêndice.
} 
Exibições em exposições de arte desde mil novecentos e noventa e cinco, entende, segundo escreveu como resposta ao questionário, que o Design de exibições deve contribuir a meu ver, na concepção desde o início.

Luiza Mello, formada em História e em História da arte e com pósgraduação em História da Arte e Arquitetura do Brasil, é também produtora executiva da Automática, empresa produtora e editora de projetos culturais cuja principal missão é aproximar o público da arte contemporânea. A empresa se especializa na elaboração, produção, gestão, coordenação, pesquisa, edição, difusão e consultoria de projetos culturais, especialmente vinculados ao universo das artes visuais. ${ }^{77}$ Durante a entrevista, seu entendimento foi no sentido de que assim que se tenha a lista das obras a serem expostas por parte do artista ou de seu curador, o Design de exibições já se pode fazer presente.

Segundo Luiza Mello, na fase que se segue a seleção das obras e do espaço da exposição, o Design de exibições deve ser aplicado a fim de dispor tais obras no espaço expositivo disponível. Afirma ainda que a participação do Design de exibições se estende durante todo o processo de montagem da exposição.

Perguntada se a atividade do Design de exibições também poderia se prolongar após a inauguração da exposição de arte, quando o evento é finalmente aberto à visitação popular, Luiza Mello responde que sim, no tocante ao acompanhamento relacionado à manutenção da exibição. Porém, percebe que fazer o acompanhamento junto ao público, a fim de se realizar uma avaliação do evento como um todo, mostra-se uma tarefa mais difícil, salvo se houver equipes do próprio museu aptas a realizarem a tarefa.

Por fim, a produtora cultural lembrou da produção de catálogos da exibição de arte como outra possibilidade de aplicação do Design de Exibições. Sabe-se que tais catálogos são bastante úteis por documentarem, após o termino da exibição, como foi elaborado o projeto expositivo, por registrarem imagens do evento e pelos comentários explicativos dos objetivos da exibição que tantas vezes fazem parte da edição.

Sylvia Steinberg também havia ressaltado durante sua entrevista a importância dos catálogos de exibições que registram para a posterioridade, por meio de fotos do evento e de textos, o que foi o evento para quem não pôde visitar

\footnotetext{
${ }^{77}$ http://www.automatica.art.br/editora/?page $=2$
} 
fisicamente a exibição, para quem a visitou e gostaria de guardá-la na memória e para estudo posterior por parte daqueles que trabalham no setor ou desenvolvem pesquisas a ele relacionadas. Trata-se de um importante e eficaz meio de transmissão, às gerações vindouras, da informação que foi à época da exibição divulgada.

Segundo Carla Juaçaba, arquiteta que iniciou seu trabalho na área de montagem de exibições (de arte ou não) como assistente de Gisela Magalhães desde a década de 1990 atuando até hoje no ramo, opinou, no decorrer da entrevista, que a participação do designer de exibições deveria preferencialmente se dar a partir do momento que o conteúdo da mostra já tenha sido largamente pesquisado e definido. Caberia ao designer desenvolver seu trabalho balizando-se nesse conteúdo pré-fixado. A arquiteta expressou sua opinião muito embora reconhecesse que seu ponto de vista poderia ser contrário ao que prega o design thinking.

Quanto somente ao que se define hoje como sendo o trabalho do designer de exibições de arte, transcrevemos o texto que descreve com precisão suas funções, publicado em 2012 no catálogo da trigésima Bienal de arte de São Paulo. O evento ocupou o Pavilhão Ciccillo Matarazzo, projetado na década de 1950 pelo arquiteto Oscar Niemeyer. ${ }^{78}$ Acreditamos, entretanto, que o escrito de Martin Corullon também ilustra com perfeição a atividade quando exercida em museus de arte ou em centros culturais:

O desenho dos espaços da $30^{\mathrm{a}}$ Bienal de São Paulo é resultado de um arranjo de diversas camadas de desejos e necessidades. Demandas curatoriais em relação à disposição de obras e artistas, às redes de relações conceituais a serem materializadas, exigências especificas de cada obra em relação à conservação, luz, posição e montagem, fluxos de pessoas na visitação, aspectos de segurança e conforto do público e a especificidade do edifício projetado por Oscar Niemeyer são algumas das variáveis que tiveram de ser orquestradas na realização do projeto expográfico da Bienal. Todos esses planos deveriam ser coordenados de modo funcional, mas, sobretudo, de modo a produzir um espaço que proporcionasse ao visitante uma experiência em sintonia com as intenções e o conceito da exposição. Para que esse jogo complexo fosse produtivo, além de premissas claras, era preciso definir instrumentos de projeto que articulassem ao máximo todos os atores que participam da constituição desse espaço, permitindo que o processo de criação fosse flexível o suficiente para manter o projeto suspenso, informe e em

\footnotetext{
${ }^{78}$ http://www.bienal.org.br/pavilhao.php
} 
transformação constante ao longo de todo o trabalho, sem prejuízo de sua coerência (CORULLON, 2012: 310).

Referindo-se especificamente ao trabalho do designer de exibições quando atua em museus de arte, Skramstad (SKRAMSTAD, In.: KLEIN, 1986: 10) alerta que projetar esse tipo de exposição difere de projetar outras modalidades pelas limitações que os objetos artísticos geralmente impõem ao serem expostos. Questões como segurança e conservação desses objetos assim como a necessidade de se compartilhar cada fragmento de informação com o curador da mostra são complicações que, segundo o autor, podem tanto destruir o designer imprudente como podem criar desafios que resultarão em uma grande exposição.

Quando questionada qual o lugar do designer no processo de elaboração e montagem de uma exibição de arte, Sylvia Steinberg respondeu que ele deixa de ser um sabe tudo, deixa de ser um autoritário impertinente e passa a ser um interlocutor que, conforme sua bagagem cultural, poderá se posicionar ao mesmo nível que o curador, o artista. Concluiu que

o papel do designer de exibições hoje é praticamente o que sempre foi, mesmo com todas as modificações e inserções que o século vinte e um trouxe. Enfim, que não há mais ninguém trabalhando só, sem ouvir ninguém. O designer trabalha em conjunto, não impõe sua vontade única.

Marta Vieira Bogéa escreveu em resposta ao questionário que lhe foi submetido que Quando uma exposição é bem montada é resultado de uma competência comum alcançada por seus autores (cada um em seu campo de saber: curador, arquiteto, iluminador, gráfico, artistas). Entretanto, entende ser tarefa especifica do designer o projeto de uma narrativa espacial materialmente delineada.

Essa natureza de trabalho coletivo é reafirmada por LORENC; SKOLNICK e BERGER. Os autores ensinam que em qualquer tipo de evento ou de situação em que os designers de exibições atuam, eles trabalham em times multidisciplinares, conjuntamente com seus clientes, para conseguirem contar uma estória à audiência almejada (LORENC et ali., 2007: 08).

Também DERNIE destaca que a tarefa de elaborar e montar exibições permanentes ou temporárias em museus exige uma cooperação intensa entre curadores, escritores acadêmicos, conservadores e restauradores, museólogos, arquitetos e designers de exibição (DERNIE, 2007: 07). O processo também 
inclui outros especialistas dos campos da ilustração, do design gráfico, de produto e de mídia, de iluminação. Também se verifica uma interface entre jornalistas, educadores e escritores acadêmicos. Enquanto que a maioria dos clientes de projetos de exibições são organizações governamentais, tais projetos são também comissionados por uma gama de instituições culturais e comerciais (DERNIE, 2007: 07).

Sylvia Steinberg lembrou que dentre as atividades exercidas pelo designer, ele deve se ocupar dos elementos de registro e de suporte, considerando para tanto questões técnicas também. Por exemplo, um suporte especialmente construído para uma exposição deve garantir segurança das obras exibidas, deve ser a princípio minimizado para não ter sua presença mais exacerbada que a própria obra, deve permitir que o visitante circule livremente no seu entorno, aproximando-se e distanciando-se facilmente. Ainda, o projeto deve oferecer uma configuração de layout do espaço que seja harmônico - nisso não se entenda uma busca por beleza, como explicou Sylvia Steinberg. Citando exemplo que deve ser evitado, uma exposição de arte que se utilize de longas paredes para distribuir os objetos não deveria concentrar uma enorme quantidade de legendas informativas em apenas um dos extremos dessa parede, sem qualquer alusão a qual obra cada legenda se refere. A intenção de não causar uma poluição estética na exposição não pode servir de desculpa para falha tão inconveniente para o visitante. No caso de questões que são absolutamente técnicas, é preciso parar de reinventar, segundo a entrevistada. Não se pode, por exemplo, obrigar idosos a lerem legendas escritas com letras minúsculas ou a se curvarem ao lê-las a fim de se permitir às crianças vê-las concomitantemente. Não se deveria incluir no espaço expositivo informações que não guardam qualquer relação com a exposição, mas que sirvam meramente a propósitos de marketing.

Sylvia Steinberg expressou que por vezes a vontade do designer não consegue se fazer valer por imposições burocráticas. Segundo opinou, não se deve achar que o gestor do espaço, o curador, o prefeito, o partido político, com ingerência no espaço, saiba algo a mais que o designer estudou quatro a cinco anos para aprender e vinte para colocar em prática.

No prefácio ao livro Museums and Money: the Impact of Funding in Exhibitions, Scholarship and Management, Victoria D. Alexander (ALEXANDRE: 1996) relatou sua pesquisa que concluiu como as exibições de 
arte em museus dos Estados Unidos da América mudaram de perfil a partir da década de 1970, o momento em que o financiamento dos museus e, por conseguinte, de suas exibições deixou de ser bancado por filantropos e passou a ter por fonte um mosaico de doadores institucionais, no caso, corporações, fundações e agências governamentais. A autora constatou que já por volta da década de 1980, os museus haviam mudado radicalmente, como reflexo dessa mudança dramática nas suas fontes de receitas. Esse livro traz à tona a extensão da influência que segmentos outros, externos ao museu de arte, exercem no que se mostra, como se mostra e quanto ao que se diz a respeito dessa mostra.

A autora escreve também que os museus, tal como qualquer organização sem fins lucrativos, precisam levantar fundos enquanto perseguem seus objetivos. Sem dinheiro os museus não podem operar. Explica que esses recursos são captados com a ajuda de doações privadas e prossegue concluindo que os doadores desses recursos sempre têm seus motivos pessoais para doar e sempre buscam algum retorno por suas ações beneméritas. Pode ser o desejo por prestígio, por visibilidade, por acessibilidade ao museu, por conselhos gratuitos sobre suas coleções privadas. Ainda que esses desejos possam parecer inócuos, a autora defende que tais demandas são problemáticas quando elas são inconvenientes para o museu, ou, pior, se quando para serem alcançadas, entram em conflito com as missões do museu. Afirma ainda que esses doadores privados costumam preferir investir em programas ou atividades distintas daquelas que um museu normalmente investiria se a questão financeira não se colocasse presente. $\mathrm{E}$ finaliza ensinando que os administradores de museus precisam lidar diariamente com a questão de como levantar recursos para as atividades da instituição sem, contudo, se submeterem demais as pressões dos doadores (ALEXANDRE: 1996).

Em resumo, Sylvia Steinberg ensinou que o designer que trabalha no projeto de elaboração e de montagem de exibições de arte deve ter em mente preservar e mostrar os objetos de arte que se deseja expor, difundir o conhecimento sobre arte, registrar o evento ocorrido para possibilitar pesquisas posteriores e assim multiplicar o acesso do que se divulgou a um número sempre crescente de pessoas.

Finalmente, segundo Sylvia Steinberg, o designer deve projetar suas exposições de arte de maneira sustentável, pois lhe parecia ser contraproducente e desproporcional a enorme despesa que envolve cada montagem e desmontagem e 
o trabalho despendido para um evento cuja duração efêmera permite o deleite apenas daqueles que lá estiveram presentes.

Prosseguiu afirmando que uma das principais características de um designer é a sua capacidade de ouvir e de entender uma situação, uma pessoa, um local. Ele há de entender o que será exposto e sob que ótica aquilo será exposto. $\mathrm{O}$ designer precisa conhecer o espaço onde os objetos serão expostos e quem é o público visitante. Observou, entretanto, que essas capacidades elencadas são exigidas não apenas em projetos de exibições de arte, mas em diversos tipos de projetos de design.

Por outro lado, Sylvia Steinberg ponderou que o designer de exposições decididamente precisa ter a capacidade do domínio do espaço e da sua gestão tridimensional, que pode ser extremamente enganosa se ele não interage com a arquitetura do prédio. Essa seria uma característica muito específica do designer segundo a entrevistada. Acrescentou que os simuladores virtuais de espaço que são empregados nos computadores mostram-se valiosos ou então desastrosos,

porque capacitam a observação do espaço por ângulos que o ser humano normalmente não experimenta. Ao permitirem a percepção de outra realidade antes escondida, não desvendada poderão, ao mesmo tempo, aventar uma disposição do espaço de um ponto de vista inexistente para as pessoas, porém totalmente permitido e possível por aquela virtualidade.

Além da mencionada gestão do espaço tridimensional e ainda quanto à especificidade da atuação do designer de exibições de arte, Sylvia Steinberg ensinou que tal profissional tem a especificidade técnica do conhecimento de tipografia, de imagem seja ela real ou virtual e da cor tal como o tem o designer gráfico e de produtos. Há ainda a sua capacidade de desenhar suportes que dialogue com o contexto do espaço e com a questão da interatividade com o público. O designer de exposições precisa ter uma curiosidade imensa por materiais e pelo processo produtivo e gráfico, precisando manter-se constantemente atualizado sobre estes temas. Concluiu que uma exposição pode contar com o trabalho de mais de um designer, mas há que haver um que conjugue todas as capacidades mencionadas até agora, colocando-se assim à frente das questões expositivas.

Perguntada sobre o que o designer que projeta a exposição comunicará, qual seu objetivo, Sylvia Steinberg ensinou que o objetivo nunca é dele, nunca, a não 
ser que ele seja coparticipante de um processo de curadoria, o que seria o ideal, ou que ele esteja viabilizando uma exposição de design. Na verdade, como explicou, ele estará a serviço, não de um objetivo, mas da visão que um curador gostaria de colocar diante do que vai ser exposto. Cada curador terá a sua própria visão e a insistência de que uma visão é certa em detrimento de outra, errada, seria bastante limitadora, segundo opinou. Um curador inteligente vai sempre buscar surpreender, sendo isso mais adequado do que buscar o certo ou errado de uma curadoria. Prosseguiu afirmando que se algo é considerado como certo, assim o é conforme um determinado código, de uma determinada sociedade, em um dado tempo e espaço. Não se trata de uma verdade universal e perene. $\mathrm{O}$ trabalho do designer consiste em dar suporte para que aquilo concebido pelo curador possa vir à tona na sua integralidade. Quando o designer se sobrepõe ao que está exposto, pode ter certeza de que algo está errado.

Algo comentado também pela entrevistada foi grande capacidade criativa de algumas pessoas que são capazes de fazer aponte entre várias atividades ligadas ao processo de criação, ainda que sem uma formação específica em Design. Citou como exemplo o mineiro Maximo Soalheiro que tem trabalhos artesanais de cerâmica, mas que também entende de tipografia, de música, de técnicas de impressão. Trata-se de alguém que desenha os suportes de suas exposições, transporta coisas dessas exposições de um lugar para outro, imprime seu próprio catálogo com a tipografia por ele escolhida, enfim, monta sua própria exibição sem requerer a colaboração de designers de exposições. Maximo Soalheiro pode ser considerado artista, designer, expositor, músico. Como observou Sylvia Steinberg, a academia ensina muitas coisas, mas há que se observar o mundo que ainda é a melhor escola.

A bibliografia sobre o tema ensina que o Design de Exibições deve se fazer presente durante todo o processo de elaboração de uma exibição, mas que há uma intensidade maior de sua atividade na fase da conceituação.

O objetivo da fase de conceituação é o de desenvolver as abordagens principais do design, servindo-se da avaliação inicial como base. Como bem descrevem Schwarz, Berton e Frey, (SCHWARZ, BERTON, FREY, 2006:12) A base de cada projeto é uma investigação detalhada, um posicionamento claro do design e uma estruturação convincente da tarefa. As autoras continuam ao afirmar que a importância dessa primeira fase é geralmente mal estimada e 
desvalorizada, mas que, entretanto, é dessa avaliação básica que emergem soluções que responderão a questões que surgirão no decorrer do projeto.

As mesmas autoras explicam sobre a necessidade do briefing ser preciso, esclarecendo que nele devem constar os seguintes pontos: temas e conteúdos; enunciados chave e intenções; requisitos, interesses e posicionamentos, estado da pesquisa; fontes; situação do objeto; determinação dos grupos alvo; análise de visitantes; pedagogia do museu/teoria educacional; fatores espaciais; preservação; condições de conservação; conceito de mobilidade e de percurso dos visitantes; orçamento (SCHWARZ, BERTON, FREY, 2006:12).

Acrescentam que a avaliação inicial considera a tarefa por diversos vieses. Os interesses dos visitantes e os interesses dos financiadores do museu nem sempre são os mesmos. Por essa razão, uma análise ampla da situação presente e de todas as áreas relevantes se mostra necessária. Isso deve preceder à introdução de medidas concretas de planejamento (SCHWARZ, BERTON, FREY, 2006:12$13)$.

Entendem ainda as autoras que a formação de grupos de trabalho cuja formação dos membros seja multidisciplinar tende a evitar abordagens de design que possam ser banais e costuma prover soluções sustentáveis. No tocante a fase de pesquisa, as autoras aconselham a prática de workshops a fim de se obter aportes dos participantes que preencham uma gama de diferentes especialidades e práticas.

Nessa fase de conceituação, mostra-se de capital importância que os fundamentos de todas as áreas de Design envolvidas no projeto já estejam estabelecidos. São eles: a apresentação tridimensional; a apresentação cenográfica; a visualização e comunicação; o papel dos objetos; os textos e as imagens, o layout e os aspectos gráficos e tipográficos; as cores; as luzes e a iluminação; acústica. Essa avaliação básica deve incluir ainda a contribuição de acadêmicos (SCHWARZ, BERTON, FREY, 2006:14).

Essa necessidade do profissional designer trabalhar em equipe já havia sido verificada por Forty.

Neste cenário, o papel do designer vai além da prancheta ou da estação gráfica. É necessário, cada vez mais, desenvolver formas de trabalho em equipe e competência acerca de ambientes como o chão de fábrica e novas tecnologias aplicadas a projetos e produção. Torna-se desta forma fundamental a adequação de programas e currículos a uma formação multidisciplinar que privilegie uma visão mais ampla do 
processo projetual e suas consequências sobre os processos de produção (FORTY, 2007:241).

Acredita-se que Larry Klein, autor recorrentemente citado na presente pesquisa, esclarece e resume de maneira relativamente condensada quais são as funções exercidas pelo designer de exibições. Embora não trate especificamente do caso em que esteja a atuar em exibição de arte em museus, acredita-se que a descrição se aplica com perfeição à situação. Ele explica que o Design de Exibições pode requerer o uso de virtualmente todo tipo de técnica de comunicação e estimular a todos os sentidos. Designers envolvidos nessa atividade devem possuir habilidade em manipular fotografias, ter noções de design gráfico e de tipografia. Devem também estar atentos à arquitetura, aos espaços interiores e exteriores, ao planejamento do deslocamento de pessoas, ao controle de multidões, ao mobiliário, à iluminação e acústica, a todos os tipos de apresentações audiovisuais, à tecnologia de computadores assim como aos materiais, à construção e aos métodos de instalações. Finalmente, o autor acrescenta que pode ser útil que esse profissional tenha seu sentido apurado para questões de tempo, de drama e de fantasia (KLEIN, 1986: 14).

David Dernie escreve que a disciplina Design de Exibição vem expandindo seus limites para além do mero design de um show ou da exibição em uma única mídia. Afirma que a abordagem do designer tende agora a considerar estratégias capazes de atingir amplamente as intenções de promoção e de desenvolvimento do cliente. Referindo-se especificamente as exibições em museus, ensina que o designer deve considerar todo o conjunto de produtos que são criados em consequência: livros, $c d$ 's, filmes, mercadorias, roupas e pensar estrategicamente em eventos ou lançamentos que promovam a marca do museu. A tarefa envolve necessariamente a presença da $W e b$ e de outras formas de mídia para atrair amplo público. Assim, o autor esclarece que montar o aspecto físico da exibição é apenas uma parte de um trabalho bem mais complexo e coordenado (DERNIE, 2007: 10). 


\section{Conclusão.}

A presente pesquisa foi desenvolvida com o objetivo de verificar a relevância da aplicação da metodologia projetual do Design na prática disso que se nomeia como Design de Exibições em exposições de arte no cenário internacional e no Brasil. Coube inicialmente esclarecer que o termo design de exibições, design de exposições, cenografia de exibições ou expografia foram entendidos como sinônimos no presente estudo. Depreendeu-se por meio de leitura de numerosos livros e artigos em língua estrangeira que o emprego de técnicas do Design de Exibições se mostra uma prática internacionalmente frequente em museus de arte. Tal fenômeno pode ser observado principalmente a partir da década de 1940 por meio das inovadoras propostas de Alfred Barr para o espaço expositivo do MoMA de Nova Iorque. Seu sucessor, René d'Harnoncourt, também precursor da utilização do Design de Exibições em exibições de arte em museus, desenvolveu um estilo diferente daquele adotado por Barr para as mostras do MoMA nas décadas de 1950 e 1960. O trabalho de ambos exerceu, e ainda exerce, forte influência na maneira de se exibir arte no resto do mundo. Diversas experiências em museus de ciência e tecnologia desenvolveram outras novas formas de montar exibições que, em maior ou menor grau, servem de inspiração para a montagem de exibições de arte, muito embora ainda se constate a prevalência da neutralidade do cubo branco. Enfim, verificou-se que a bibliografia internacional sobre o Design de Exibições é farta e a relevância da atividade já foi confirmada há longos anos nos Estados Unidos da América e em diversos países da Europa.

No Brasil, as pesquisas e publicações sobre o tema se verificaram escassas até o presente momento e, dessa forma, o presente estudo desejou oferecer uma modesta contribuição à bibliografia nacional, produzida principalmente a partir dos anos 2000. Por meio de respostas a questionário e de entrevistas que foram realizadas com designers, arquitetos e produtores culturais que atuam em exibições de arte em museus e centros culturais cariocas, nacionais e por vezes 
estrangeiros, obteve-se material que revelou bastante sobre o modo como o Design de Exibições é aplicado por aqui em mostras de arte, sobre o quotidiano da atividade, sobre quais são as funções e capacidades exigidas dos profissionais que trabalham no ramo e os desafios que enfrentam, e sobre em que momentos eles devem atuar. Os dados obtidos pela pesquisa de campo foram analisados em conjunto com a bibliografia nacional e internacional lida sobre o tema. Dessa maneira buscou-se desenvolver um estudo comparado, sempre considerando as diferenças que necessariamente se evidenciam quando se cotejam realidades diversas.

No tocante a verificação da relevância da aplicação do Design de Exibições às exibições de arte em nossos museus e centros culturais, o que se constatou foi que o seu emprego já se confirmou como necessário e benéfico quer seja pela sua capacidade de criar narrativas que contextualizam os objetos expostos, ou pelo emprego de recursos que os evidenciam e os correlacionam, tudo isso no intuito de facilitar a compreensão e a fruição do que se exibe, além de proporcionar a participação ativa do público sempre que possível, fazendo da visitação uma experiência sensitiva agradável e intelectualmente estimulante. Confirmou-se que o material informativo sobre as exibições serve como importante fonte de referência para futuros estudos sobre o evento. Sua produção (catálogos e demais peças gráficas para divulgação da mostra) é realizada por designers de exibição ou gráficos, sendo provavelmente a única tarefa de todo o processo de concepção e montagem de exibições de arte preferencialmente exercida por designers. A respeito das demais tarefas exigidas para a realização do evento, tais como dispor os objetos no espaço expositivo, iluminá-los, criar narrativas, propor trajetos de visitação, produzir os textos e as legendas explicativas sobre os objetos da mostra, concluiu-se, tanto por meio das entrevistas colhidas como pela leitura da bibliografia em língua estrangeira sobre o tema, que diversas categorias profissionais são aptas a exercê-las. Com base na bibliografia em língua estrangeira sobre Design de Exibições, não se comprovou a existência de uma capacidade especifica da qual apenas o designer seria dotado. Ao contrário, autores como Klein e Lorenc et ali afirmam que múltiplas categorias profissionais vêm exercendo a atividade com sucesso. Com o designer de exibições concorrem principalmente arquitetos, artistas das artes visuais, cenógrafos. Dessa maneira, não se conseguiu esboçar um possível escopo de atuação que fosse 
preferivelmente reservado aos designers no processo de concepção e montagem de exibições de arte em museus.

Quanto ao ensino do Design de Exibições no Brasil, concluiu-se que a disciplina, embora não seja unanimemente assim considerada, ainda não é largamente ministrada nas grades curriculares das universidades ou de cursos de Design do Rio de Janeiro, ou até possivelmente do nosso país. Os motivos aventados para explicar o fato foram três: primeiramente, a indefinição quanto a sua classificação como disciplina no Campo do Design. Em segundo,a complexidade da matéria que exige conhecimentos de diversos campos do saber como, por exemplo, o Design, a Museologia, a Arquitetura, a Sociologia e a Psicologia, a Tecnologia, as Artes Cênicas. Entendeu-se que essa grade multidisciplinar exigida para o ensino de uma única disciplina poderia ser um desafio árduo de ser transposto no Brasil visto que, normalmente, os cursos universitários aqui ministrados tendem a concentrar o ensino de suas disciplinas a uma área especifica do conhecimento humano. Por último, a indefinição existente quanto à especificidade da metodologia do projeto do Design e do Design de Exibições poderia reforçar a resistência, por parte das universidades e cursos de design do Brasil, em ministrar a referida disciplina.

Finalmente, quanto ao potencial educativo do Design de Exibições como facilitador do aprendizado sobre arte e sobre história da arte pelo público, confirmou-se que sua habilidade para comunicar informações sobre os objetos de arte expostos de maneira clara e dinâmica não são sempre suficientes para garantir acompreensão das obras, especialmente as contemporâneas. A participação do Design de Exibições nesse sentido foi percebida como coadjuvante, mas não como decisiva para o sucesso do objetivo de popularizar o conhecimento sobre arte e seus conceitos. Assim, os catálogos, os textos e os vídeos explicativos de exibições de arte assim como a disposição das obras de forma a criar uma narrativa e uma contextualização, além do emprego de técnicas de iluminação, de cores ou de paralelismos de formas colaboram para que o conteúdo da mostra, delimitado previamente pelo curador, seja transmitido. Podem ajudar o público. Entretanto, fez-se imperativo incluir nesse trabalho a constatação da autora Sandra Sunierno sentido de que esse discurso prévioproposto pelo curador, pela política institucional do museu e por seus financiadores, por exemplo, muitas vezes não é aparente na exibição ou quando transparece, é apresentado de maneira 
codificada.Certamente alguns dirão que cabe ao público entender o que vê de acordo com sua bagagem cultural, decodificando por meio de seu próprio esforço o conteúdo exposto, acrescentando que as mensagens veiculadas na exibição não devem ser impostas. Concordou-se em parte com tal opinião, acreditando-se aplicável quando considerado um público já detentor de um determinado grau de instrução, normalmente universitário. Entretanto, acredita-se importante ressalvar que nem sempre a bagagem cultural possuída pelo visitante lhe permite sair de uma exibição de arte com algum sentimento de satisfação. Novamente cita-se o estudo de Bourdieu e Darbel realizado nos anos de mil novecentos e sessenta na França que, em linhas gerais, concluiu que só se vê aquilo que se conhece previamente. Os autores, por exemplo, referem-se à classe camponesa francesa que, geralmente desprovida de conhecimentos básicos sobre arte, entrava e saia de museus de arte sem compreender o que via e sem usufruir a visitação, sentindo-se até mesmo constrangida em certas ocasiões, diminuída pela percepção da própria ignorância. Certamente esse não é o objetivo de nenhum museu. Acredita-se que a realidade de considerável parcela da população brasileira atual não difere tanto da acima descrita pelos dois pesquisadores. Falta-lhe o conhecimento das múltiplas referências visuais e conceituais utilizadas pelas artes plásticas. Na presente pesquisa concluiu-se, portanto, que o Design de exibições não consegue suprir sozinho essacarência. O caminho para tanto requer a coparticipação de um setor educativo forte nos museus e, principalmente, a definição de uma meta governamental de ensinar arte e sua história de modo crítico nas escolas frequentadas pelas mais variadas camadas da população brasileira. 


\section{Referências bibliográficas.}

ABREU, Regina. A metrópole contemporânea e a proliferação dos "museus-espetáculo". Anais do Museu Histórico Nacional, v. 44, Rio de Janeiro, p. 53-72, 2012,.

ALEXANDER, Victoria D., Museums and Money: the Impact of Funding in Exhibitions, Scholarship and Management. USA: Indiana University Press, 1996.

ARTMONSKY, Ruth. Exhibiting Ourselves: Fifty Years of British Exhibition Design. London: Artmonsky Arts, 2014.

AZEDA, Helena Cunha de. Os limites de fruição em exposições de arte: padrões dos espaços de observação das obras nas galerias. Anais do Museu Histórico Nacional, V.43, Rio de Janeiro, p.115-126, 2011.

BEAUD, Stéphane; WEBER, Florence. Guia para a Pesquisa de Campo. Produzir e analisar dados etnográficos. Rio de Janeiro: Editora Vozes Ltda., 2007.

BERTASO, Maria Stella Tedesco; BRAGA, Marcos da Costa. Sistemas expositivos projetados por Bergmiller. O caso do MAM RJ. In: 9o Congresso Brasileiro de Pesquisas e Desenvolvimento em Design, 2010, disponível em http://docplayer.com.br/6240032-Sistemas-expositivosprojetados-por- bergmiller.html acesso em 29/11/2016

BOGLE, Elizabeth. Musem Exhibition Planning and Design. United Kingdom: Altamira Press, 2013.

BOIME, Albert. Art in an Age of Revolution, 1750-1800. A social history of modern art. v.1, Chicago and London: The University of Chicago Press, 1987.

BOURDIEU, Pierre. Economia das Trocas Simbólicas. São Paulo: Editora Perspectiva S.A., 5르. Ed., 2001.

BOURDIEU, Pierre; DARBEL, Alain. L'amour de l'art les musées d'art européens et leur public. Paris: Les Editions de Minuit, 1969.

BRAGA, Marcos da Costa. Correspondência (mensagem pessoal). São Paulo: 03 de março de 2017. 
BRUNO, Maria Cristina Oliveira. Os caminhos do enquadramento, tratamento e extroversão da herança patrimonial. Caderno de diretrizes museológicas 2: mediação em museus: curadoria, exposições e ações educativas. Belo Horizonte: Secretaria de Estado de Cultura de Minas Gerais, Superintendência de Museus, 2008.

BURLURAUX, Odile; SCHERF, Angeline; SEIDEL, Charlotte. Entretemps: uma década de vídeo arte francesa na coleção do Musée d'Art Moderne de La Ville de Paris. Rio de Janeiro: Instituto Telemar, São Paulo: anônima, 2009.

CASTILLO, Sonia Salcedo del. Cenário da Arquitetura da Arte, Montagens e Espaços de Exposições. São Paulo: Martins Fontes, 2008.

CAUQUELIN, Anne. Arte Contemporânea. Uma Introdução. São Paulo: Martins Fontes, 2005.

CAVALCANTI, Ana Maria Tavares; MALTA, Marize (Org.); PEREIRA, Sonia Gomes (Org.). Coleções de arte: formação, exibição e ensino. $1^{\text {a }}$ ed., Rio de Janeiro: Rio Books, 2015. V.1

CIPINIUK, Alberto. A ideologia comercial do século XVIII e a transição dos estilos. In.: Couto, Rita Maria de Souza. Oliveira, Alfredo Jefferson de; Farbiaz, Jackeline Lima; Novaes, Luiza. Rio de Janeiro: Rio Book's, $2^{a}$ Edição Revisada e ampliada, 2014.

COELHO, Frederico. Museu de Arte Moderna: arquitetura e construção. Rio de Janeiro: Cobogó, 2010.

COELHO, Teixeira. Dicionário Crítico de Política Cultural. Cultura e Imaginário. São Paulo: Editora lluminuras, 1997.

CORULLON, Martin. Roteiro de projeto: a expografia da Bienal como processo. Catálogo da 30 $3{ }^{\mathrm{a}}$ Bienal de São Paulo: A iminência das poéticas. Curadores Luiz Perez Oramas [et al], São Paulo: Fundação Bienal de São Paulo, 2012.

COSTA, Álvaro Augusto de Carvalho. A Real Preservação do MAM-RIO. In: X Seminário Docomomo Brasil Arquitetura Moderna e Internacional: conexões brutalistas 1955-75. Curitiba 15-18 out. 2013, PUCPR.

CRIMP Douglas. The Art of Exhibition. October, Vol. 30 (Autumn), The MIT Press, 1984, pp. 49-81.

CURY, Marilia Xavier. Exposição: concepção, montagem e avaliação. São Paulo: Editora AnnaBlume, 2006. 
DAVALLON, Jean; GOTTESDIENER, Hanna; POLI, Marie-Sylvie. The expert visitor' concept, In.: Museum International (UNESCO, Paris), no. 208 (Vol. 52, No. 4, 2000), UK, USA: Blackwell Publishers, p.60.

DECAROLIS, Nelly. Muséologia, Interpretación y Comunicación: El Publico de Museos, ICOFOM Studies Series ISS 35, International Committe for Museology, 2005.

DENIS, Rafael Cardoso. As origens históricas do designer: algumas considerações iniciais, Estudos em Design, volume IV, no2, dezembro, 1996, Rio de Janeiro: Associação de Ensino de Design do Brasil.

DEOTTE, Jean Louis; HUYGHE, Pierre. Le jeu de l'exposition. Paris: L'Harmattan, 1998.

DERNIE, DAVID. Exhibition Design. London: Laurence King Publishing Ltd, 2007.

DESVALLÉES, Andre et MAIRESSE François, Key Concepts of Museology. Paris: Armand Colin, 2010.

DUBIN, Steven C. Displays of Power. Controversy in the American Museum from the Enola Gay to Sensation. New York and London: New York University Press, 1999, p.1-18.

FALCON, Francisco. A formação do mundo contemporâneo. Rio de Janeiro: Campus, 1981.

FINDELI, Alain. Rethinking design education for the 21st century: theoretical, methodological, and ethical discussion. Design issues, volume 17, number 1, winter 2001.

FORTY, Adrian. Objects of Desire. Design and Society since 1750. London: Thames and Hudson, 2005.

FORTY, Adrian. Objeto de desejo - design e sociedade desde 1750. São Paulo: Cosac Naify, 2007.

GIL, A. C. Como elaborar um projeto de pesquisa. São Paulo: Editora Atlas, 1987.

GOB, ANDRE et DROUGEUT, NOEMIE, La Muséologie. Histoire, développements, enjeux actuels. 3e édition, Paris: Armand Colin, 2010.

GONÇALVES, Jose Reginaldo Santos. Prefácio. SANTOS, Myrian Sepúlveda dos. A escrita do passado em museus históricos. Rio de Janeiro: Garamond, MinC, IPNHAN, DEMU, 2006. 
GONÇALVES, Lisbeth Rebollo. Entre Cenografias: o museu e a exposição de arte no século XX. São Paulo: Editora da Universidade de São Paulo/Fapesp, 2004.

GRANDMONT, Gérald. Prefácio. SCHIELE, Bernard. Patrimonies et identités. Quebec: Colection muséo. Editions Multimondes. 2002.

GUELTON, Bernard. L'Exposition, interprétation et réinterpretation. Paris: L'Harmattan, p.104

HEGEWISCH, Katharina. Un Médium a La Recherche de sa Forme. Les Expositions et Leurs Déterminations. L'Art de l'exposition: une documentation sur trente expositions exemplaires du $\mathrm{XX}^{\mathrm{e}}$ siècle. Editions du Regard, 1998, p.15-33.

HEINRICH, Fabiana Oliveira; CIPINIUK, Alberto. Design: crítica à noção de metodologia de projeto. Rio de Janeiro, 2013, 242p. Dissertação de Mestrado - Departamento de Artes \& Design, Pontifícia Universidade Católica do Rio de Janeiro.

HINCAPIE, Gabriel Mendez.; RESTREPO, Ricardo Sanim. La constitucion encriptada. Nuevas formas de emancipacion del poder global. Revista de Derechos Humanos y Estudios Sociales, ano IV n.8, San Luis Potosí, Mexico, 2012. Disponível em http://www.academia.edu/11957948/LA CONSTITUCI\%C3\%93N ENCRI PTADA_Nuevas_formas_de_emancipaci\%C3\%B3n_del_poder_global acesso em 29/12/2016.

HOBSBAWN. Eric. Tempos fraturados. Cultura e sociedade no século XX. Rio de Janeiro: Companhia das Letras, 2013.

HUGHES, Philip. Exhibition Design. London: Laurence King, 2015.

IDEMA, Johan. How to visit an art museum, tips for a truly rewarding visit. Amsterdam: BIS Publishers, 2014.

JAPIASSU, Hilton. Nascimento e morte das ciências humanas. Rio de Janeiro: Francisco Alves,1982.

JAPIASSU, Hilton. Introdução ao pensamento epistemológico. Rio de Janeiro: Francisco Alves, 1991.

LAKATOS, Eva Maria; MARCONI, Marina de Andrade. Fundamentos de Metodologia Científica. São Paulo: Editora Atlas, 2003.

LATOUR, Bruno. A cautious Prometeu. A few steps toward a philosophy of design (with special attention to Peter Sloterdijk).Keynote lecture for the Networks of Design meeting of the Design History Society Falmouth, Cornwall, 3rd September 2008. Disponível em http://www.bruno- 
latour.fr/sites/default/files/112-DESIGN-CORNWALL-GB.pdf acesso em 25/01/2017.

LEON, Ethel. Design em exposição: o design no Museu de Arte Moderna do Rio de Janeiro (1968-1978), Na Federação das Indústrias de São Paulo (1978-1984) e no Museu da Casa Brasileira (1986-2002). tese sob orientação da Professora Dra. Maria Cecília França Lourenço, São Paulo, 2012.

LEON, Ethel. IAC Primeira Escola de Design do Brasil. São Paulo: Editora Edgar Blucher, 2014.

LOCKER, Pam. Basics interior design 02: Exhibition Design. Switzerland: AVA Publishing SA.

LORENC, lan; SKOLNIC, Lee; BERGER, Craig. What is Exhibition Design? Singapore: Page One Publishing Private Limited, 2007.

LUZ, Angela Ancora da. Uma Breve História dos Salões de Arte: da Europa ao Brasil. Rio de Janeiro: Caligrama Edições, 2005.

LYOTARD, Jean-François. L'inhumain. Causeries sur le temps. Paris: Éditions Galilée, 1988.

MAIRESSE François et DESVALLÉES Andre (dir.), Vers une redéfinition du musée?, Paris: L'Harmattan, 2001.

MAIRESSE François, La Notion de Public, ICOFOM Studies Series ISS 35, International Committe for Museology, 2005.

MAIRESSE François. Un demi-siècle d'expographie. Culture \& Musées, $n^{\circ} 16,2010$. La (r)évolution des musées d'art (sous la direction de André Gob \& Raymond Montpetit) pp. 219-229.

MARINCOLA, Paula. What makes a Great Exhibition?. US: Philadelphia Exhibitions Initiative, 2010.

MARTINS, Maria Helena Pires. Prefácio. CURY, Marília Xavier. Exposição: concepção, montagem e avaliação. São Paulo: Editora Annablume, 2005, p.9.

MASSON, Michel Nunes Lopes; CIPINIUK, Alberto. O espaço de exibição de obras de arte. Dissertação de mestrado do programa de Pós-Graduação em Design da PUC-Rio, Rio de Janeiro, 2004.

POULOT Dominique, Musée et Muséologie, Paris: La Découverte, 2005.

RANCIERE Jacques, L'espectateur emancipé, Paris: La fabrique éditions, 2008. 
ROSSINI, Elcio. Cenografia no teatro e nos espaços expositivos: uma abordagem além da representação. In.: Transformação, Campinas, 24(3):157-164, 2012, disponível em www.scielo.br/pdf/tinf/v24n3/a01v24n3 acesso em 11/01/2017.

SAJAD, Nelson; Brandão, Carlos Roberto F., A exposição como processo comunicativo na política curatorial. Cadernos de diretrizes museológicas 2. Mediação em museus: curadorias, exposições e ação educativa. Belo Horizonte: Secretaria de Estado de Cultura de Minas Gerais/Superintendência de Museus, 2008.

SANTOS, Irina Aragão dos. Correspondência (mensagem pessoal). Rio de Janeiro, 03 de março de 2017.

SCHEINER, Teresa Cristina. O Museu como Processo. Cadernos de diretrizes museológicas 2. Mediação em museus: curadorias, exposições e ação educativa. Belo Horizonte: Secretaria de Estado de Cultura de Minas Gerais/Superintendência de Museus, 2008.

SCHWARTZ, Karla; CIPINIUK, Alberto. O processo colaborativo nos Campos do Design e da Arte: pinceladas sobre o Design de Exibições. Revista Tamanduá - Design, Arte e Representação Social. N.3, V.1, ano 3 (2016), Rio de Janeiro, p. 20-43, disponível em www.revistatamandua.grudar.com, acesso em 24/02/2016.

SCHWARZ, Ulrich; BERTON, Aurelia; FREY, Claudia. Designing exhibitions. A Compendium for Architects, Designers and Museum Professionals. Ausstellungen entwerfen. Kompendium für Architekten, Gestalter und Museologen. Basel, Boston, Berlin: Birkhäuser - Publishers for Architecture, 2006.

SERAPIÃO. Fernando. A nuvem. Inhotim, arquitetura e paisagem. São Paulo: Revista Monolito, $n^{\circ}$ 4, agosto-setembro 2011.

SHAH, Anita. Museums and Audience, ICOFOM Studies Series ISS 35, International Committee for Museology, 2005.

SUNIER, Sandra. Le scénario d'une expostion. Public et Musées, $n^{\circ} 11$ 12, 1997. Marketing et Musées (sous la direction de Jean-Michel Tolebem), p.195-211.

THORNTON, Sarah. Sete dias no mundo da arte: Bastidores, tramas e intrigas de um mercado milionário. Rio de Janeiro: Agir, 2010.

URURAHY, Heloisa Pinto. Museus na internet do século XXI: a caminho do museu ubíquo. Dissertação de mestrado. Orientador Artur Matuck, Universidade de São Paulo, 2013.

VIAL, Stéphane.Court traité du design. France: Puf, 2014.

VINÇON, René. Artifices d'exposition. Paris: L'Harmattan, 1999. 


\section{Apêndices.}

\section{Questionário}

No início das entrevistas explica-se que se pretende compreender melhor o Design de exibições em quatro de seus aspectos: sua aplicação no Brasil em museus de arte; sua capacidade de potencializar o diálogo entre o objeto exposto, o espaço de exposição e o público visitante; sua capacidade de transmitir ao público a(s) mensagem(ns) da exibição de arte de forma clara e dinâmica; habilidades especificas do designer de exibições e sua atuação em exibições de arte.

1-Qual a sua formação escolar e acadêmica?

2-Há quanto tempo atua na área de Design de Exibições em exposições de arte? Qual o percentual (do total de projetos) que essa atividade representa em seu trabalho?

3-Você acha que o Design de exibições já é bem conhecido, divulgado e aplicado em exposições de arte no Brasil?

A)Caso sim, porque e exemplos de exposições.

a.1) O Brasil desenvolveu uma expressão própria, um modo característico de aplicar o Design de exibições em exposições de arte em seus museus? Ou a influência estrangeira ainda se mostra determinante?

B)Caso não, qual o motivo?

4-O que você entende por Design de Exibições quanto as suas funções, estatutos e singularidades?

5-Quando o designer projeta uma exibição, o que ele quer comunicar? Qual a sua intenção?

6-A utilização dos princípios do Design de Exibições gera um diferencial nas exposições de arte? Qual e como?

7-Em que momentos da elaboração de uma exibição o Design de exibições pode auxiliar? 
8-Como o Design de exibições evidencia o objeto exposto a fim de valorizá$10 ?$

9-Que outras categorias profissionais atuam em conjunto com o designer quando elaborando uma exposição? Há lugar para o designer nesse processo?

10- No processo de elaboração de exposições de arte, quais seriam as funções do designer? De todas as funções exercidas, o que você entende ser especifico do designer?

11- No contexto de elaboração de exposições de arte contemporânea, deveria o designer realizar um trabalho com algum enfoque diferenciado?

12- A aplicação do Design de exibições em exposições de arte em museus é capaz de facilitar o aprendizado sobre arte pelo público não especializado? É também capaz de atrair mais público?

13- Há outros aspectos importantes do Design de exibições (em museus de arte mais especificamente) que não perguntei anteriormente e que merecem ser abordados?

14 - Em uma exibição de arte há uma ou mais mensagens a transmitir aos visitantes? A mensagem é dada por quem? Ou deve-se entender que essa ideia de mensagem é ultrapassada quando da elaboração de uma exibição de arte, a fim de se permitir ao visitante entender o que vê como bem deseja, utilizando suas próprias referencias para compreender a exibição?

Entrevistas e respostas ao questionário

As entrevistas e as respostas ao questionário que informam o presente texto podem ser solicitadas por meio do seguinte email: kgsrio@gmail.com 